FLÁVIA MORATO

Avaliação da atividade micobactericida de desinfetantes químicos utilizando a técnica de cultivo em camada de ágar Middlebrook 7H11

São Paulo

2007 


\section{Avaliação da atividade micobactericida de desinfetantes químicos utilizando a técnica de cultivo em camada de ágar Middlebrook 7H11}

Dissertação apresentada ao Programa de PósGraduação em Epidemiologia Experimental e Aplicada às Zoonoses da Faculdade de Medicina Veterinária e Zootecnia da Universidade de São Paulo para obtenção do título de Mestre em Medicina Veterinária

\section{Departamento:}

Medicina Veterinária Preventiva e Saúde Animal

Área de concentração:

Epidemiologia Experimental e Aplicada às Zoonoses

Orientadora:

Prof $^{a}$. Dr ${ }^{a}$. Sônia Regina Pinheiro

São Paulo 


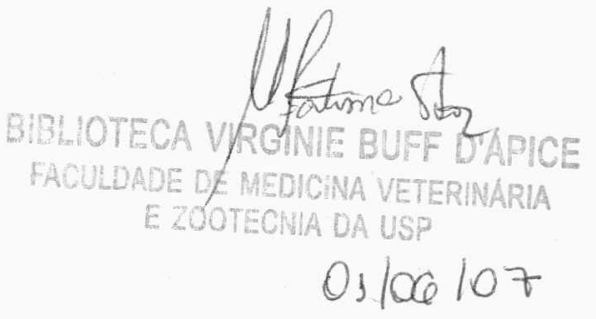

DADOS INTERNACIONAIS DE CATALOGAÇÃO-NA-PUBLICAÇÃO

(Biblioteca Virginie Buff D'Ápice da Faculdade de Medicina Veterinária e Zootecnia da Universidade de São Paulo)

T $1800 \quad$ Morato, Flavia

FMVZ Avaliaçào da atividade micobacterieida de desinfetantes quimicos utilizando a técnica de cultivo em camada de agar Middlebrook 7H1l Flavia Morato. Sào Paulo: F. Morato, 20(0)7

$84 \mathrm{f}$ : : il.

Disscrtaçào (mestado) - Universidade de Sào Paulo. Faculdade de Medicina Veterinaria e Zootecnia. Departamento de Medicina Veterinaria Preventiva c Saride Animal, 20(0)7.

Programa de Pos-Ciraduaço: Fpidemologia Fexprimental e Aplicada as Zoonoses.

Area de concentração: Fpidemiologia Fxperimental e Aplicada as Zoonoses.

Oricntador: Prof". Dr ${ }^{+1}$ Sonia Regina Pinheiro.

1. Desinfetante. 2. Macohacherimm horis. 3. Tuberculase t. Middlebrook 71111. 5. Caprino. 1. Titulo. 


\section{UNIVERSIDADE DE SÃO PAULO \\ Faculdade de Medicina Veterinaria e Zootecnia \\ Assistência Acadêmica}

Comissão de Bioética

\section{CERTIFICADO}

Certificamos que o Projeto intitulado "Avaliação da atividade micobactericida de desinfetantes químicos utilizando a técnica de cultivo em camada de ágar Middlebrook $7 \mathrm{H} 11 "$, protocolo $\mathrm{n}^{\circ} 754 / 2005$, não será utilizado animais no experimento, sob a responsabilidade da Profa. Dra. Sônia Regina Pinheiro, está de acordo com os princípios éticos de experimentação animal da Comissão de Bioética da Faculdade de Medicina Veterinária e Zootecnia da Universidade de São Paulo e foi aprovado "ad referendun".

(We certify that the Research "Evaluation of mycobactericidal activity of chemical disinfectants using the Middlebrook $7 \mathrm{H} 11$ agar medium" protocol number 754/2005, won't be utilized animals, under the responsibility of Profa. Dra. Sônia Regina Pinheiro, agree with Ethical Principles in Animal Research adopted by Bioethic Commission of the Faculty of Veterinary Medicine and Zootechny of University of São Paulo and was approved "ad referendun", meeting).

São Paulo, 07 de outubro de 2005

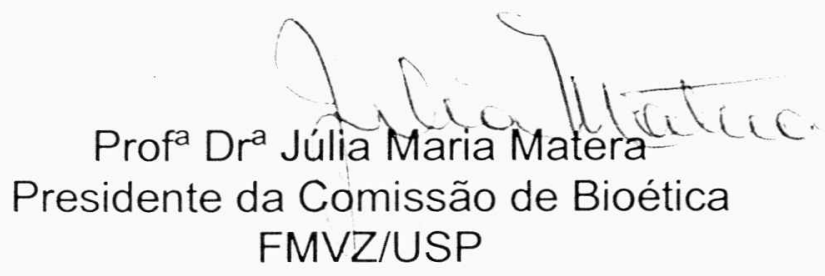




\section{FICHA DE AVALIAÇÃO}

Nome: MORATO, Flávia

Título: Avaliação da atividade micobactericida de desinfetantes químicos utilizando a técnica de cultivo em camada de ágar Middlebrook 7H11

Data:

Dissertação apresentada ao Programa de PósGraduação em Epidemiologia Experimental e Aplicada às Zoonoses da Faculdade de Medicina Veterinária e Zootecnia da Universidade de São Paulo para obtenção do título de Mestre em Medicina Veterinária

Banca Examinadora

Prof. Dr.

Instituição

Assinatura

Julgamento

Prof. Dr.

Instituição

Assinatura

Julgamento

Prof. Dr.

Instituição

Assinatura

Julgamento 
Dedico

Aos meus pais,

José Petrônio (in memoriam)

e Ivone 


\section{AGRADECIMENTOS}

À Professora Sônia Regina Pinheiro, pela orientação, amizade, confiança e incentivo mesmo nas etapas mais dificeis deste projeto.

Ao Professor Silvio Arruda Vasconcellos pelo acolhimento no Laboratório de Zoonoses Bacterianas.

Ao Professor Ricardo Dias pela amizade, paciência e essencial apoio na análise estatística dos resultados.

A Zenaide e à Gisele pela amizade, pela ajuda imprescindivel na realização de todo o experimento, pelo aprendizado, dedicação, sugestões e principalmente pela paciência.

À minha família (Lu \& Lu e Marininha) pelo apoio, incentivo e companheirismo. As Tias Glória e Paula pela presença e ajuda nas últimas etapas.

Ao Gustavo pelo companheirismo e carinho.

À amiga Amane pela ajuda técnica, emocial e incentivo desde o inicio dessa jornada.

Ao Bispo pela amizade e ajuda com as fotos do projeto.

A Jucélia pela ajuda com os resultaods estatíticos.

Ao Lincoln pela ajuda na formatação e Maria Clara pela ajuda na revisão.

A todos os amigos do Laboratório de Zoonoses Bacterianas: Viviane, Marianna, André, Daniela, Paty, FlaviaCarol, Pilar, Pancho, Carlos, Dona Odete e aos estagiários e residentes que passaram por lá.

Aos amigos do VPS: Alessandra, Iara, Sheila, Sandra, Danival, Cristina, Virginia, Sabrina, Fernanda, Carol pelo companheirismo, apoio e incentivo, e por todos os inúmeros momentos de diversão.

À FAPESP pela concessão da bolsa de mestrado, e apoio financeiro para a realização desta pesquisa.

Aos funcionários da Biblioteca pelas sugestões e ajuda crucial na conclusão deste trabalho. 


\section{RESUMO}

MORATO, F. Avaliação da atividade micobactericida de desinfetantes químicos utilizando a técnica de cultivo em camada de ágar Middlebrook 7H11. [Evaluation of mycobactericidal activity of chemical disinfectants using the Middlebrook 7H11 agar medium technique]. 2007. xx f. Dissertação. (Mestrado em Medicina Veterinária) - Faculdade de Medicina Veterinária e Zootecnia, Universidade de São Paulo, São Paulo, 2007.

Avaliou-se a atividade micobactericida de cinco desinfetantes químicos frente a uma estirpe de Mycobacterium bovis isolada de caprinos, tipificada por PCR (polymerase chain reaction) e com 32 dias de cultivo no meio de Stonebrink. O teste de desinfetantes foi realizado utilizando-se a técnica de cultivo em camada delgada de ágar Middlebrook 7H11 modificado e foi comparado ao teste em tubos com meio de Stonebrink, tradicionalmente utilizado no laboratório de zoonoses bacterianas da FMVZ/USP. Os cinco desinfetantes ensaiados foram: "A" : grupo controle; "B" - hipoclorito de sódio (2,5\% de cloro ativo); "C"- glutaraldeído (2 \%); "D" - ácido peracético $0,25 \%$ e peróxido de hidrogênio $5 \%$; "E" - iodóforo $(2,6 \%$ de iodo) e "F"- compostos fenólicos (orto-fenilfeno 12,243 g; orto-benzil paraclorofenol 11,080 g; para-terceário amilfeno 4,1222 g.). A diluição destes produtos foi feita conforme recomendação do fabricante. Os meios de cultura adotados para o procedimento de isolamento e preparo da suspensão bacteriana foram o meio de Stonebrink e o meio de Middlebrook 7H11 modificado. Os testes foram realizados na presença e ausência de matéria orgânica e à temperatura ambiente $\left(21 \pm 2{ }^{\circ} \mathrm{C}\right)$ e à temperatura de $4{ }^{\circ} \mathrm{C}$. Os resultados obtidos nas contagens de colônias foram transformados em percentual de redução para análise estatítica e demostraram que: a técnica de cultivo de micobactérias em camada delgada no meio de Middlebrook 7H11 permitiu uma visualização precoce das micobactérias e se mostrou viável para realização de testes de desinfetantes; os cinco tipos de desinfetantes analisados apresentaram atividade micobactericida e o melhor desempenho foi obtido pelo ácido peracético seguido pelo hipoclorito de sódio. A atividade micobactericida dos iodóforos foi instisfatória na presença de matéria orgânica.

Palavras-chave: Desinfetantes; Mycobacterium bovis; tuberculose; Middlebrook; caprino. 


\begin{abstract}
MORATO, F. Evaluation of mycobactericidal activity of chemical disinfectants using the Middlebrook 7H11 agar medium technique. [Avaliação da atividade micobactericida de desinfetantes químicos utilizando a técnica de cultivo em camada de ágar Middlebrook 7H11]. 2007. xx f. Dissertação. (Mestrado em Medicina Veterinária) - Faculdade de Medicina Veterinária e Zootecnia, Universidade de São Paulo, São Paulo, 2007.
\end{abstract}

The mycobactericidal activity of five chemical disinfectants was evaluated against a strain of Mycobacterium bovis isolated from a goat, typified by PCR (polymerase chain reaction) and with 32 days of growth in the Stonebrink medium. The disinfectants were tested using the modified thin layer Middlebrook 7H11 cultivation technique and it was compared to the test made in tubes with Stonebrink medium, which is tradicionally used at the Bacterian Zoonosis Laboratory of the Veterinary Medicice Faculty of the University of São Paulo. The five disinfectants were: "A" was the control group; "B"- sodium hypochlorite $(2,5 \%$ of active chlorine); "C"- glutaraldehyde (2 \%); "D"- peracetic acid $(0,25 \%)$ and hydrogen peroxide (5 \%); "E" - iodine compounds (2,6\%) e "F"- fenolic compounds (orto-fenilfeno 12,243 g; ortobenzil paraclorofenol 11,080 g; para-terceario amilfeno 4,122 g.). The products were diluted according to label instructions. The culture media used for the isolation procedure and preparation of the bacterian suspension were the Stonebrink and modified Middlebrook 7H11 medium. The assays were performed either in the presence or absence of organic matter, at temperatures of $4{ }^{\circ} \mathrm{C}$ and $21 \pm 2{ }^{\circ} \mathrm{C}$ The colony counting results were transformed into reduction percentages for the statistical analysis and concluded in: the modified thin layer Middlebrook 7H11 cultivation technique permitted an earlier visualization of the colonies and was practible for the realization of the disinfectants tests; the five disinfectants showed mycobactericidal activity and the peracetic acid had the best performance followed by the sodium hypochlorite. The mycobactericidal activity of the iodine compound was unsatisfactory when in the presence of organic matter.

Key-words: Disinfectants; Mycobacterium bovis, tuberculosis, Middlebrook; caprine. 


\section{LISTA DE FIGURAS}

Figura 1 - Placa de Petri com quadriculado e área de leitura demarcada (L) ...

Figura 2 - Colônias de M. bovis aos 7 dias de cultivo em meio de Middlebrook 7H11 modificado. Visualização sob microscopia óptica com aumento de $100 \mathrm{x}$

Figura 3 - Colônias de M. bovis aos 7 dias de cultivo em meio de Middlebrook 7H11 modificado. Visualização sob microscopia óptica com aumento de $100 \mathrm{x}$

Figura 4 - Colônias de M. bovis aos 21 dias de cultivo em meio de Stonebrink

Figura 5 - Colônias de M. bovis aos 28 dias de cultivo em meio de Stonebrink 


\section{LISTA DE TABELAS}

Tabela 1 - Percentual de redução de crescimento de M.bovis em placas com 7H11, segundo o princípio ativo do desinfetante químico, a temperatura de contato, presença ou ausência de matéria orgânica. São Paulo 2007.

Tabela 2 - Percentual de redução de crescimento de M.bovis na superfície do meio de Stonebrik em tubos, segundo o princípio ativo do desinfetante químico, a temperatura de contato e presença ou ausência de matéria orgânica. São Paulo - 2007 


\section{LISTA DE GRÁFICOS}

Gráfico 1 - Atividade micobactericida dos desinfetantes em placas com meio 7H11 na temperatura ambiente e ausência de matéria orgânica...........

Gráfico 2 - Atividade micobactericida dos desinfetantes em placas com meio 7H11 na temperatura ambiente e presença de matéria orgânica

Gráfico 3 - Atividade micobactericida dos desinfetantes em placas com meio $7 \mathrm{H} 11$ na temperatura de $4{ }^{\circ} \mathrm{C}$ e ausência de matéria orgânica.

Gráfico 4 - Atividade micobactericida dos desinfetantes em placas com meio 7H11 na temperatura de $4{ }^{\circ} \mathrm{C}$ e presença de matéria orgânica.

Gráfico 5 - Atividade micobactericida dos desinfetantes em tubos com meio de Stonebrink na temperatura ambiente e ausência de matéria orgânica..

Gráfico 6 - Atividade micobactericida dos desinfetantes em placas com meio 7H11 na temperatura ambiente e presença de matéria orgânica

Gráfico7 - Atividade micobactericida dos desinfetantes em tubos com meio de Stonebrink na temperatura de $4{ }^{\circ} \mathrm{C}$ e ausência de matéria orgânica....

Gráfico 8 - Atividade micobactericida dos desinfetantes em tubos com meio de Stonebrink na temperatura de $4{ }^{\circ} \mathrm{C}$ e presença de matéria orgânica. 


\section{LISTA DE ABREVIATURAS}

\begin{tabular}{|c|c|}
\hline$\%$ : & Por cento \\
\hline $\mathrm{C}:$ & Graus Celsius \\
\hline$\mu \mathrm{L}:$ & Microlitro \\
\hline AFNOR: & Association Française de Normalization \\
\hline AIDS: & Acquired Immunodeficiency Syndrome \\
\hline AOAC: & Association of Official analytical chemists \\
\hline $\mathrm{cm}:$ & Centímetro \\
\hline cmo: & Com matéria orgânica \\
\hline FMVZ: & Faculdade de Medicina Veterinária e Zootecni \\
\hline g: & Grama \\
\hline HIV: & Human Immunodeficiency vírus \\
\hline M. bovis: & Mycobacterium bovis \\
\hline M. tuberculosis: & Mycobacterium tuberculosis \\
\hline $\mathrm{mL}:$ & Mililitro \\
\hline mo: & Matéria orgânica \\
\hline P.C.R.: & Polymerase Chain Reaction \\
\hline p.s.: & Pós semeadura \\
\hline $\mathrm{pH}:$ & Potencial hidrogeniônico \\
\hline PNCBET: & $\begin{array}{l}\text { Programa Nacional de Combate e Erradicação da Brucelose e } \\
\text { Tuberculose }\end{array}$ \\
\hline q.s.p: & Quantidade suficiente para \\
\hline smo: & Sem matéria orgânica \\
\hline
\end{tabular}




\begin{tabular}{|l|l|}
\hline Ta: & Temperatura ambiente \\
\hline U.F.C.: & Unidades Formadoras de Colônias \\
\hline USP: & Universidade de São Paulo \\
\hline WHO: & World Health Organization \\
\hline
\end{tabular}




\section{ÍNDICE}

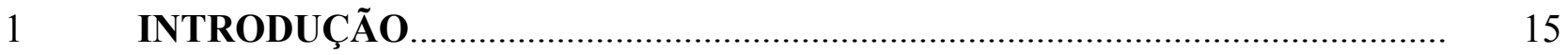

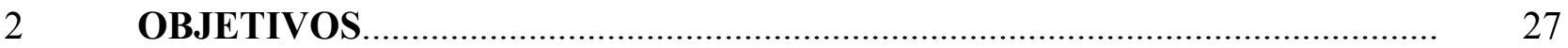

$2.1 \quad$ OBJETIVOS ESPECÍFICOS.............................................................................. 28

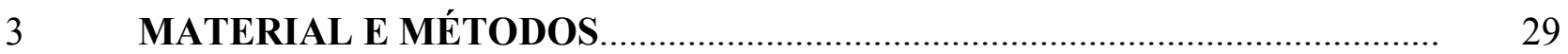

3.1 SUSPENSÃO DO MICRORGANISMO TESTE ………………………………..... 30

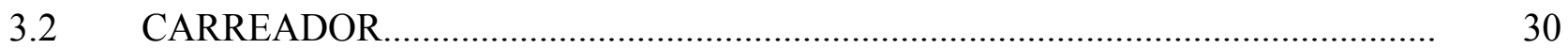

3.3 MEIOS DE CULTURA.................................................................................. 30

3.4 FONTE DE MATÉRIA ORGÂNICA................................................................... 31

3.5 DESINFETANTES QUÍMICOS $\quad$........................................................................ 31

3.6 SOLUÇÃO NEUTRALIZANTE..........................................................................

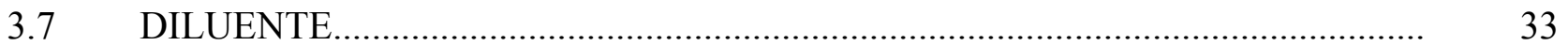

3.8 TÉCNICA DE QUANTIFICAÇÃO DAS UNIDADES FORMADORAS DE COLÔNIAS (U.F.C.) PARA LEITURA DO CRESCIMENTO NO MEIO DE STONEBRINK

3.9 TÉCNICA DE QUANTIFICAÇÃO DAS UNIDADES FORMADORAS DE COLÔNIAS (U.F.C.) PARA LEITURA DO CRESCIMENTO NAS PLACAS DE CAMADA DELGADA DE MIDDLEBROOK 7H11 MODIFICADO........................ 33

3.10 PROCEDIMENTOS EXPERIMENTAIS............................................................... 34

3.10.1 Delineamento Experimental.................................................................................. 35

3.10.2 Inoculação dos Meios de Cultura.......................................................................... 36

3.11 TRATAMENTO ESTATÍSTICO ..................................................................... 36

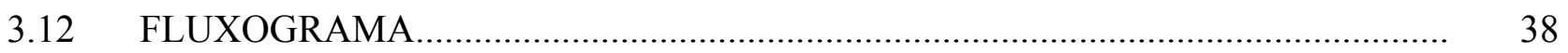

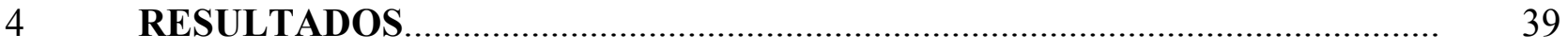

4.1 AVALIAÇÃO DO DESEMPENHO DOS DESINFETANTES NO TESTE EM PLACAS COM MEIO 7H11............................................................................ 42

4.1.1 Avaliação da atividade micobactericida entre os desinfetantes na técnica em placas. 43

4.1.2 Avaliação da atividade micobactericida dos desinfetantes frente à variável matéria orgânica na técnica em placas.

4.1.3 Avaliação da atividade micobactericida dos desinfetantes frente à variável temperatura na técnica em placas 
4.2 AVALIAÇÃO DO DESEMPENHO DOS DESINFETANTES NO TESTE EM TUBOS COM MEIO DE STONEBRINK........................................................ 44

4.2.1 Avaliação da atividade micobactericida entre os desinfetantes na técnica em tubos...

4.2.2 Avaliação da atividade micobactericida dos desinfetantes frente à variável matéria orgânica na técnica em tubos

4.2.3 Avaliação da atividade micobactericida dos desinfetantes frente à variável temperatura na técnica em tubos

5 DISCUSSÃ̃

6 CONCLUSÕES

REFERÊNCIAS.

ANEXO 

INTRODUÇÃO 


\section{INTRODUÇÃO}

A tuberculose é uma doença transmissível de grande importância em saúde pública e saúde animal, pois determina um quadro de doença de elevada gravidade no homem, e acarreta acentuadas perdas econômicas, devido à diminuição da produtividade dos rebanhos afetados (PINHEIRO,1990; PINHEIRO, 1999).

Kleeberg (1984), citou que a tuberculose humana, provocada geralmente pelo Mycobacterium tuberculosis, acarretou, anualmente na Europa, a morte de pelo menos três milhões de pessoas e enumeravam-se dez milhões de novos casos a cada ano. Sob condições favoráveis, o Mycobacterium bovis pode causar, em seres humanos, as mesmas formas clínicas e lesões patológicas que o M.tuberculosis (ACHA; SZYFRES, 1986), e a infecção de seres humanos pelo M.bovis ocorre, principalmente pela via aerógena, ou pela ingestão de alimentos contaminados.

A informação epidemiológica sobre o impacto da tuberculose zoonótica provocada pelo M.bovis no homem, na América Latina, é escassa ou limitada a algumas regiões (KANTOR; RITACCO, 1994; ORGANIZACION PANAMERICANA DE LA SALUD, 1995). Há necessidade de um trabalho conjunto entre profissionais da área humana e veterinária, pois o M.bovis tem particularidades que dificultam o seu isolamento, quando feito sem uma solicitação específica do médico junto ao laboratório de análise (PINHEIRO, 1999).

A pandemia da síndrome da imunodeficiência adquirida, AIDS, está associada a infecções oportunistas, principalmente tuberculose e doenças causadas pelo complexo $M$. avium (FREITAS et al., 2001). A tuberculose é a principal infecção oportunista em pessoas HIV - positivas, e a maioria das pessoas duplamente infectadas pelo M.bovis e pelo vírus HIV vive em países em desenvolvimento. A epidemia de infecção pelo HIV nestes países, particularmente naqueles em que a infecção por M.bovis está presente nos animais e há condições favoráveis à transmissão desta zoonose, pode fazer da tuberculose zoonótica uma séria ameaça de saúde pública para populações de risco (COSIVI et al., 1998). Na década de 
90, a tuberculose atingiu pessoas infectadas pelo HIV com uma severidade alarmante, causando uma doença rapidamente disseminada que envolvia vários órgãos (MILLER; PAIGE, 1998).

O M.bovis tem sido considerado agente causador de infecção em caprinos, ovinos, suínos, animais de zoológico e de vida selvagem (LUKE 1958; THOEN, 1988; BERNABÉ et al., 1991; MORRIS; PFEIFFER; JACKSON, 1994).

Mohan (1950), revisando a literatura sobre a tuberculose em caprinos, descobriu que o primeiro relato da enfermidade foi realizado por Robert Koch, em 1884. Contudo, os caprinos eram considerados resistentes à infecção natural pela tuberculose, sendo tal "crença" confirmada pelo fato do consumo de leite de vaca ter sido substituído pelo de cabra, como medida profilática contra a tuberculose humana (MURRAY; MCNUTT; PURWIN, 1921; SOLIMAN et al., 1953; LUKE, 1958).

No Brasil, em relação ao manejo nutricional dos caprinos jovens, é frequentemente, fornecido leite de bovinos para esta categoria animal. Esta prática poderia propiciar a transmissão de infecção a estes animais, pois já no início do século passado, Griffith (1928) relatou o diagnóstico da tuberculose em caprino amamentado com leite de vaca.

A incidência da tuberculose nos caprinos, faz desta espécie uma fonte potencial de infecção aos seres humanos, devendo ser considerada um problema no avanço de programas de erradicação da tuberculose (THOREL, 1980; LIÉBANA et al., 1998; SEVA et al., 2002).

O Programa Nacional de Controle e Erradicação da Brucelose e Tuberculose Animal (PNCEBT) foi instituído em 2001 pelo MAPA com o objetivo de diminuir o impacto negativo dessas zoonoses na saúde comunitária e de promover a competitividade da pecuária nacional. O PNCEBT introduziu a vacinação obrigatória contra brucelose bovina e bubalina em todo o território nacional e definiu uma estratégia de certificação de propriedades livres ou monitoradas onde essas enfermidades são controladas com rigor (MINISTÉRIO DA AGRICULTURA, PECUÁRIA E ABASTECIMENTO, BRASIL 2007). 
Evoluindo de criações voltadas para a subsistência, hoje a expansão do agronegócio da caprino e ovinocultura está transformando o cenário produtivo no Brasil. O mercado vem crescendo rapidamente, exigindo uma maior preocupação com aspectos sanitários. A produção de caprinos e ovinos deve ser fundamentada em sistemas de exploração que possam garantir melhores condições sanitárias para estes animais, através de medidas de Biossegurança e de exames diagnósticos confiáveis e acessíveis. Através da Instrução Normativa No 87 da Secretaria de Defesa Agropecuária, de 10 de dezembro de 2004, foi aprovado o regulamento técnico do PNSCO. O controle e erradicação das doenças de caprinos e ovinos, por meio de ações sanitárias e de vigilância epidemiológica definidas pelo Diretório de Defesa Animal (DDA-MAPA) e executadas pelos serviços oficiais e médicos veterinários cadastrados, estão entre os objetivos do programa. Dentre as estratégias de atuação, serão destacadas: o cadastro de estabelecimentos, o controle de trânsito de animais, a certificação de estabelecimentos, o cadastramento de médicos veterinários do setor privado e o credenciamento de laboratórios para realização de exames diagnósticos das doenças de controle oficial (MAPA, 2007).

Atualmente, o PNSCO encontra-se em fase de estruturação. Foi formado um comitê técnico científico, composto de profissionais dos diversos setores da caprino e ovinocultura, com o objetivo de dar suporte técnico às decisões do programa. As propostas sanitárias estão em fase de conclusão e estão sendo disponibilizadas por meio de consulta pública, de maneira a permitir a participação de todos setores interessados (MAPA, 2007).

Nos países onde foram executados programas de controle da tuberculose bovina, houve uma drástica redução na freqüência de casos humanos por este agente. Muito antes da descoberta de medicamentos para o tratamento dos doentes, a tuberculose já estava diminuindo nos países desenvolvidos, pois os programas sanitários adotados abrangiam linhas de ação em relação às fontes de infecção, às vias de transmissão e aos animais suscetíveis (KLEEBERG, 1984). Dentre as principais ações aplicadas nos programas sanitários, destacam-se os procedimentos de desinfecção como instrumento efetivo no combate ao agente da doença no meio ambiente (POLIAKOV, 1975; VERA et al., 1985). 
Bier (1985) conceituou desinfecção como sendo o ato de destruir apenas os microrganismos patógenos. A desinfecção é, pois, um caso particular da esterilização, que se refere especificamente à eliminação dos germes patogênicos, sem que haja, necessariamente, a destruição de todos os microrganismos.

Kroning e Paul (apud BLOCK, 1983) publicaram, em 1897, um trabalho onde relataram que as bactérias, imersas em uma solução desinfetante, não morriam todas ao mesmo tempo e que a taxa de redução do seu número variava, em função da temperatura e da concentração da solução empregada. Concluíram, portanto, que se fazia necessário controle das condições gerais ao se avaliar a ação dos desinfetantes. O número de bactérias deveria ser constante na ausência da matéria orgânica, pois esta interferia sob o mecanismo de ação dos produtos.

A necessidade de uma freqüente avaliação dos desinfetantes está embasada no princípio de que a análise química dos produtos não fornece todas as informações necessárias para a mensuração de sua atividade antimicrobiana (ALTERTHUM, 1977); isto é possível com a execução de ensaios que avaliem adequadamente a influência de outros fatores tais como: o tipo e a origem da estirpe que está sendo testada, o preparo do inóculo, o princípio ativo do produto químico e a sua respectiva concentração, bem como a seleção dos produtos neutralizantes (TILLEY, 1939; TILLEY, 1942; WHITMORE; MINER, 1976; WIEST, 1978; CROSHAW, 1981; GÉLINAS; GOULET, 1983; WORLD HEALTH ORGANIZATION, 1984; GAGLARDI, 1985; GONTIJO FILHO; ROMÃO, 1986; HURTADO; VERA, 1986; TIMENETSKY, 1987; TIMENETSKY, 1990; PINHEIRO et al., 1992; CASTILLO GUERRERO et al., 1993; PINHEIRO et al., 1997).

Dentre os fatores que podem modificar a eficiência dos desinfetantes químicos, merecem especial destaque os seguintes: a concentração do desinfetante, a temperatura, o pH ambiental, a dureza da água, o tipo de microrganismo e a presença de matéria orgânica (SARAUT; LAUTIÉ, 1960; ITO et al., 1978; KRONING; PAUL, 1897 apud BLOCK, 1983; RUSSEL, 1982;; JONES et al., 1983; GÉLINAS et al., 1984; HERNANDEZ; ESTRADA, 1984; KOSTENBAUDER, 1983; WORLD HEALTH ORGANIZATION, 1984). 
No âmbito dos desinfetantes químicos com atividade sobre micobactérias, os ensaios já realizados têm destacado a eficácia dos produtos cujo mecanismo de ação é representado pela desnaturação das proteínas microbianas (HUGO, 1967; HUGO, 1982). Neste particular, os compostos fenólicos, o formaldeído, o glutaraldeído, os compostos clorados, o iodo e os iodóforos têm sido os mais eficazes (COSTIGAN, 1936; COLLINS; MONTALBINI, 1976; COLLINS, 1986; WAIBICH, 1986; PINHEIRO, 1990).

As micobactérias apresentam elevada capacidade de sobrevivência às mais variadas condições ambientais, e por este motivo, têm sido alvo de estudo por parte de outros pesquisadores há décadas. Wang et al. (2005) afirmou que as micobactérias são mais resistentes a desinfetantes que às demais bactérias em estado vegetativo devido à parede celular rica em lipídios. Os valores fornecidos pela World Health Organization (1984) demonstraram a sobrevivência de micobactérias por períodos de até dois anos em instalações contaminadas, e de um ano, na água e no esterco. Blood e Anderson (1983) citaram o isolamento destes microrganismos em fezes de bovinos, mantidas em condições ambientais, por períodos com duração variável de até oito semanas. Williams e Hoy (1930) isolaram o bacilo da tuberculose bovina, em estrume animal armazenado durante quatro meses.

Com relação aos testes para avaliação da atividade micobactericida de desinfetantes químicos, a escolha da estirpe teste tem sido bastante variada; no entanto, como as micobactérias mais patogênicas (como a M.bovis) apresentam crescimento muito lento nos meios de cultura tradicionais, nos ensaios preliminares tem sido dada à preferência para as micobactérias menos patogênicas e de rápido crescimento nos meios de cultura (PINHEIRO, 1990). Desta forma o M.smegmatis é preconizado pela AFNOR (1977) e AOAC (1990) e o M.fortuitum é recomendado pela WHO (1984).

Do ponto de vista diagnóstico, principalmente de tuberculose provocada por M.bovis, as principais desvantagens da cultura são: a necessidade de cuidados na manipulação dos espécimes clínicos e o tempo necessário entre a semeadura e o surgimento de colônias macroscopicamente visíveis, o que leva de 24 a 40 dias em média (KONEMAN et al., 2001). 
Alguns países desenvolveram métodos próprios para avaliar a atividade micobactericida dos produtos químicos, mas de uma maneira geral, todos recomendam que, nos testes finais, seja feita uma avaliação utilizando-se estirpes patogênicas (BERGAN; LISTAD, 1971). Deste modo, o M.bovis é recomendado nos ensaios confirmativos da AOAC (1990) e o M.tuberculosis nos testes da DGHM (DEUTSCHE GESELLSCHAFT FUR HYGIENE UND MIKROBIOLOGIE-DGHM, 1972). No Brasil, as normas vigentes preconizam a utilização de M.bovis e M.tuberculosis (FUNDAÇÃO OSWALDO CRUZ, 1985).

Os ensaios confirmatórios para a avaliação da atividade micobactericida dos desinfetantes químicos de uso pecuário deverão ser executados com amostras recém isoladas de tecidos animais (PINHEIRO, 1990, 1994, 2001).

No comércio estão disponíveis diversos tipos de desinfetantes químicos; no entanto , o critério para a escolha de um determinado princípio ativo é o potencial que o mesmo apresenta para o combate ao agente que se deseja eliminar. Os produtos com atividade micobactericida recomendados são os compostos fenólicos, o ácido peracético, os álcoois e o glutaraldeído (CROSHAW, 1971; ASCENZI, 1996; AYLIFEE et al., 1993; RUSSEL, 1996). Rubin (1983) destaca a atividade do formaldeído, iodo, iodóforos e dos compostos clorados.

O fenol é um dos mais antigos germicidas, sua eficácia foi demonstrada por Lister em 1867. Como grupo, os fenóis e cresóis, particularmente os compostos à base de ortofenilfenol, em solução a 1:200, têm revelado atividade sobre micobactérias de um modo geral (MCDONNELL; RUSSELL, 1999). São considerados estáveis e não são inativados pelo sabão, nem pela matéria orgânica, razão pela qual têm sido considerados como desinfetantes de escolha para tratamento de superfícies com contaminação fecal. Apresentam ação corrosiva e são irritantes de mucosas (SPAULDING et al., 1977; PRINDLE, 1983).

A atividade micobactericida dos compostos iodados, geralmente comercializados como iodóforos, pode ser alterada quando estes produtos são diluídos em água alcalina (água dura ou seja, com alto teor de sais de cálcio e magnésio dissolvidos) ou na presença de matéria orgânica (WORLD HEALTH ORGANIZATION, 1984). 
Os compostos clorados incluem o cloro, os hipocloritos, as cloraminas, o ácido cloroisocianúrico e seus derivados. Estes produtos apresentam um largo espectro de atividade antimicrobiana; no entanto, apresentam baixa atuação sobre esporos e seu poder micobactericida é discutido (ZANON, 1973). Zanon (1973) e Linton et al. (1987) alegaram que a atividade micobactericida dos clorados é deficiente; no entanto Smith (1971) indicou o hipoclorito de sódio como potente agente micobactericida e a WHO (1984) descreveu a descontaminação de diversos materiais que possa tido contato com micobactérias, através da cloramina a $5 \%$.

Pinheiro et al. (1992) investigaram a influência da matéria orgânica na atividade micobactericida de cinco desinfetantes, utilizando para o teste uma estirpe de $M$. fortuitum , obtendo bons resultados com o hipoclorito de sódio (2,5\% de cloro ativo) e com uma mistura de aldeídos. Castillo-Guerrero et al. (1993) avaliaram a ação micobactericida de diversas concentrações de hipoclorito de sódio comercial com 2,5\% de cloro ativo, contra estirpe de M. fortuitum, observando que a ausência de matéria orgânica determinou uma atividade micobactericida quatro vezes mais elevada. Pinheiro (2001), avaliou a atividade micobactericida de desinfetantes químicos sobre estirpes de M. avium isoladas de suínos abatidos no Estado de Santa Catarina e conclui que o produto à base de fenóis e o hipoclorito de sódio apresentaram as melhores atividades micobactericidas em relação a uma estirpe de M. avium testada.

Dentre os fatores que podem influenciar a atuação dos hipocloritos são mencionados o $\mathrm{pH}$, a temperatura, a concentração do produto e a matéria orgânica. A elevação do $\mathrm{pH}$ diminui a atividade do hipoclorito (HEKMATI; BRADLEY, 1979; DYCHDALA, 1983; GÉLINAS; GOULET, 1983; RUBIN, 1983; GÉLINAS et al., 1984; WHO, 1984; LINTON et al., 1987; SAKO et al., 1988; BEST et al., 1990).

No grupo dos aldeídos, os produtos com ação germicida mais estudada são: o glutaraldeido e o formaldeido (LINTON et al., 1987). O glutaraldeido possui atividade esporicida duas a oito vezes mais elevada que a apresentada pelo formaldeído, não é corrosivo nem irritante, no entanto também apresenta alguma toxicidade (BORICK, 1968). Quando o glutaraldeido é alcalinizado, em solução aquosa a $2 \%$, apresenta grande atividade bactericida 
e esporicida. A atividade antimicrobiana do glutaraldeído depende do $\mathrm{pH}$, sendo mais intensa em pH alcalino (COLLINS, 1986; LINTON et al. 1987). Em solução de pH 4 e com aumento da temperatura, há uma elevação do seu poder germicida; no entanto, em pH 8, as elevações da temperatura são acompanhadas de reduções na atividade bactericida (SCOTT; GORMAN, 1983).

A potente atividade micobactericida do glutaraldeído foi relatada por Borick et al. (1964) e Snyder e Cheatle (1965); no entanto Rubbo et al. (1967) demonstraram que a sua ação sobre o M. tuberculosis foi lenta e, segundo Bergan e Listad (1971), menos efetiva do que o formaldeído e inclusive o hipoclorito (RELYVELD, 1977).

Collins e Montalbine (1976) demonstraram a rápida ação dos aldeídos em temperatura ambiente. Miner et al. (1977), empregando o método preconizado pela AOAC, testaram o glutaraldeído alcalinizado sobre M.bovis, obtendo 100\% de eficiência em dez minutos. Carson et al. (1978) obtiveram o mesmo resultado, com dois minutos de exposição, empregando $M$. chelonei e M. fortuitum como microrganismo teste.

Leers (1980) recomendou o uso do glutaraldeído a 2 \% para a desinfecção de endoscópios. Os aldeídos são comumente utilizados para desinfecção em hospitais, sendo o glutaraldeído o mais utilizado principalmente para desinfecção de equipamentos, devido ao seu amplo espectro de ação e potencial microbicida (BRITISH SOCIETY OF GASTROENTEROLOGY, 1993 apud Vizcaino et. al., 2002). Entretanto, sua atividade micobactericida já foi questionada pela incapacidade de penetração nas camadas mais internas da parede celular da micobactéria. Apesar do uso de maquinários automatizados ter diminuído a exposição dos trabalhadores ao glutaraldeído e conseqüentes efeitos colaterais de sua toxicidade, isso permanece um problema para a saúde dos trabalhadores (RUSSEL, 1982).

Segundo Hernandez et al. (2003b) o ácido peracético pode ser uma alternativa viável ao glutaraldeído, pois possui amplo espectro de ação microbicida mesmo na presença de matéria orgânica, e é considerado um desinfetante de alto nível de desinfecção pela FDA (Food and Drug Association). O ácido perácetico é hidro e lipossolúvel e se torna não tóxico quando é decomposto. É um agente oxidante potente e pode ser corrosivo. No entanto, existem 
formulações comerciais de misturas balanceadas de ácidos peracéticos e acéticos com peróxido de hidrogênio que não são corrosivos e possuem rápida atividade micobactericida (HOLTON et al., 1995). Hernández et al. (2002) utilizou um produto comercial, com 0,26\% de ácido peracético, contra estirpes de M. tuberculosis, M. avium-intracellulare, M. fortuitum and M. chelonae, e obteve boa ação micobactericida em 20 minutos.

O peróxido de hidrogênio está entre os microbicidas mais antigos que se conhece, e é gerado naturalmente em muitas condições. Entretanto, é relativamente instável por natureza e sua ação é relativamente lenta quando utilizado sozinho (OMIDBAKHSH et al., 2006). Essas características do peróxido de hidrogênio foram analisadas e atualmente é possível produzir formas estáveis de $\mathrm{H}_{2} \mathrm{O}_{2}$ em solução e acelerar sua atividade microbicida. A tecnologia AHP (Peróxido de hidrogênio acelerado) combinou esses avanços para aumentar a capacidade microbicida do peróxido de hidrogênio, resultando em formulações variadas de diversas aplicações (SATTAR et al., 2002).

O cultivo das micobactérias é muitos mais caro do que a baciloscopia. Requer estufas incubadoras, meios de cultura, autoclaves para preparação e descontaminação dos materiais utilizados e exige recurso humano mais qualificado, uma vez que o risco de infecção quando se trabalha com culturas de bactérias patogênicas são maiores. Entretanto, esta técnica é muito mais acessível aos laboratórios com menos recursos (principalmente nos paises em desenvolvimento) e aos médicos veterinários do que as modernas técnicas radiométricas e métodos envolvendo engenharia molecular, como a reação em cadeia da polimerase (PCR), dado o alto custo dos equipamentos para esses exames (SCHABERG et al., 1995; MEJIA et al., 1999).

Os meios de Löwenstein-Jensen para o M. tuberculosis e Stonebrink para o M.bovis, são habitualmente empregados nos laboratórios de diagnóstico bacteriológico da tuberculose pela alta eficácia no primo-isolamento dessas micobactérias em material de campo (CENTRO PANAMERICANO DE ZOONOSIS, 1988). Outros meios utilizados com resultados variáveis são os meios ATS (American Thoracic Society), Petragnani e Coletsos para o $M$. tuberculosis e, para o M.bovis, os meios de Löweinstein-Jensen com piruvato, TB agar sangue 
(B83), meio de Gerloff e meio de Herrold com gema de ovo (CORNER; NICOLAPOULOS, 1988; KONEMAN et al., 1993; IDIGORAS et al., 1995).

O M.bovis tem difilculdade em se desenvolver em meios glicerinados, e por este motivo se desenvolve melhor no meio de Stonebrink, onde o glicerol é substituído pelo piruvato de sódio. Para o isolamento primário do M.bovis recomenda-se uma pequena concentração de $\mathrm{CO}_{2}$ (não superior à 5\%), já que o M.bovis é microaerófilo (ABRAHÃO, 1998).

Considerando o fator crescimento lento de micobactérias patogênicas nos meios de cultura tradicionais, atualmente, uma avaliação da atividade micobactericida de desinfetantes químicos que atenda às recomendações já mencionadas anteriormente, levaria cerca de quatro meses para ser realizado.

O aperfeiçoamento do método microbiológico convencional para um rápido diagnóstico representa uma grande vantagem na luta contra a tuberculose no homem e no bovino (SCHABERG et al., 1995; MEJIA et al., 1999). Além disso, permitiria a realização de avaliações da atividade de produtos químicos frente a micobactérias patogênicas em um período de tempo mais curto, influenciando diretamente na velocidade das ações profiláticas e sanitárias dos programas de controle da tuberculose.

Durmaz et al. (1985), Welch et al. (1993), Idigoras el al. (1995), Mejia et al. (1999) e Smoskovi e Magyar (1999) demonstraram as vantagens do diagnóstico da técnica de camada delgada que se baseia na observação precoce de microcolônias de micobactérias em placas com uma fina camada de meio de Middlebrook 7H11, frente ao método tradicional de cultivo em meios de Löwenstein-Jensen e Stonebrink. Esses trabalhos demonstram significativa redução no tempo para a observação das primeiras colônias com elevada sensibilidade em favor da técnica de camada delgada, além de permitir a identificação preliminar das micobactérias por suas características morfológicas.

Marcondes, em 2002, concluiu que a técnica de camada delgada em placas permitiu visualização precoce das micobactérias, quando comparadas aos meios de Stonebrink e Petragnani. Apesar do abundante crescimento de colônias com três dias de cultivo, as 
colônias puderam ser melhor visualizadas a partir do $5^{\circ}$ e $6^{\circ}$ dia, quando o fator corda passou a ser mais evidente. Além disso, a técnica da camada delgada permitiu a diferenciação morfológica entre as estirpes padrão M.bovis (AN5) e M.tuberculosis (H37Rv) aos 13 dias de cultivo.

Dib, em 2005, utilizou a técnica de cultivo de micobactérias em camada delgada no meio de Middlebrook 7H11, em amostras de leite experimentalmente inoculado, empregando a estirpe padrão M.bovis (AN5), provando ser viável a utilização dessa técnica quando comparada às técnicas tradicionais. Concluiu também que a técnica da camada delgada permitiu a visualização precoce das micobactérias, quando comparada ao meio de Stonebrink.

A técnica da camada delgada oferece como principais vantagens, resultados mais precoces e a possibilidade do estabelecimento de uma identificação preliminar da micobactéria isolada, baseando-se nas características morfológicas das colônias e, portanto, pode ser utilizada como um método complementar para o diagnóstico da tuberculose humana e animal (MARCONDES, 2002; DIB, 2005).

A técnica de camada delgada dispensa microscópios especiais ou qualquer outro aparato técnico sofisticado, e pode ser usada em qualquer laboratório. Os técnicos que a executam devem ser treinados; porém, o aprendizado é rápido (IDIGORAS et al., 1995).

Até o momento, não há registros na literatura pesquisada sobre um "teste rápido" de desinfetantes utilizando-se estirpes patogênicas de M.bovis recém isoladas de material de campo. Desta forma, justifica-se o presente trabalho, que pretende validar uma técnica de cultivo em camada delgada de ágar Middlebrook 7H11 para o teste da atividade micobactericida de desinfetantes químicos, com a intenção de reduzir assim o tempo de realização do teste, acelerando a indicação de um produto desinfetante eficaz. 


\section{OBJETIVOS}

Utilizando uma estirpe de M. bovis isolada de caprinos, provenientes de uma propriedade localizada no Estado de São Paulo, foi delineado o presente estudo com o objetivo de verificar a viabilidade da utilização da técnica de cultivo em camada delgada de ágar Middlebrook 7H11 (modificado) em testes com desinfetantes químicos.

\subsection{OBJETIVOS ESPECIFICOS}

- Comparar resultados obtidos no cultivo em placas com os resultados dos testes efetuados em tubos, com meio de Stonebrink, tradicionalmente utilizados no laboratório de zoonoses bacterianas da Faculdade de Medicina Veterinária e Zootecnia da Universidade de São Paulo, para avaliação da desinfetantes químicos.

- Avaliar a atividade micobactericida de cinco desinfetantes químicos de diferentes categorias, testados frente à estirpe de $M$. bovis isolada de caprinos. 
MATERIAL E MÉTODOS 


\section{MATERIAL E MÉTODOS}

A metodologia empregada para a realização das dez repetições feitas no projeto é descrita nos tópicos abaixo.

\subsection{SUSPENSÃO DO MICRORGANISMO TESTE}

A estirpe de Mycobacterium bovis utilizada neste experimento foi isolada de um caprino atendido no hospital veterinário da Faculdade de Medicina Veterinária da Universidade de São Paulo no ano de 2001 (BENESI et. al., 2006). A amostra foi então tipificada por PCR e mantida em meio de cultura de Stonebrink (CENTRO PANAMERICANO DE ZOONOSIS, 1979) (Anexo A).

A diluição empregada foi de $0,06 \mathrm{~g}$ de colônias raspadas da superfície (peso úmido) do meio de cultura com 32 dias de cultivo em 100mL de salina (PINHEIRO et al., 1997). Estas proporções foram determinadas com base em ensaios piloto, de modo que as contagens nos controles estivessem ajustadas na faixa de leitura 300 a 400 Unidades Formadoras de Colônias (U.F.C.) segundo Pinheiro (1990).

\subsection{CARREADOR}

Círculos de dois centímetros de diâmetro, desenhados com grafite e recortados de uma folha de papel de filtro do tipo xarope $(50 \times 50 \mathrm{~cm})$, gramatura de $250 \mathrm{~g} / \mathrm{m}^{2}$, foram utilizados como agente carreador. 


\subsection{MEIOS DE CULTURA}

Os meios de cultura adotados para o procedimento de isolamento e preparo do inóculo foram o meio de Stonebrink e o meio Middlebrook 7H11 modificado (UNIVERSIDAD DE LAS NACIONES UNIDAS, 1998) (Anexo B). O meio de Stonebrink foi distribuído em tubos de vidro (180 x $18 \mathrm{~mm})$ com tampa de algodão hidrofóbico, em volume de $7 \mathrm{~mL}$ por tubo, enquanto que o meio de Middlebrook 7H11 modificado foi distribuído em placas de Petri de plástico $(60 \mathrm{X} 15 \mathrm{~mm})$, no volume de $7 \mathrm{~mL}$ por unidade. Todas as partidas foram submetidas aos testes de esterilidade e crescimento.

\subsection{FONTE DE MATÉRIA ORGÂNICA}

Soro de coelho esterilizado por processo de filtração em placas Seitz ${ }^{\circledR}$ com meio filtrante do tipo EKS/2 foi utilizado como fonte de matéria orgânica.

\subsection{DESINFETANTES QUÍMICOS}

Foram utilizados cinco desinfetantes químicos pertencentes a categorias diferentes frente a um grupo controle que utilizou a solução salina $0,85 \%$. Do grupo dos halogênios foi selecionado o hipoclorito de sódio; do grupo dos aldeídos, o glutaraldeído; do grupo dos ácidos e dos agentes oxidantes utilizou-se um produto com ácido peracético e peróxido de hidrogênio; dos compostos iodados, escolheu-se o iodophor e para representar o grupo dos fenóis, um desinfetante à base de compostos fenólicos. A diluição destes produtos foi feita conforme recomendação do fabricante.

Produto A( placebo) : solução salina a $0.85 \%$ 
Desinfetante A: Hipoclorito de sódio ${ }^{1}$. Produto com a seguinte composição:

Cloro ativo. $2,50 \%$

Veículo qsq $100,00 \mathrm{~mL}$

Desinfetante B: Glutaraldeído ${ }^{2}$. Produto com a seguinte composição:

Glutaraldeído $2,00 \%$

Veículo qsq $100,00 \mathrm{~mL}$

Desinfetante C: Ácido peracético ${ }^{3}$. Produto com a seguinte composição:

Ácido peracético $.0,25 \%$

Peróxido de hidrogênio $5,00 \%$

Veículo estabilizante. $100,00 \mathrm{~mL}$

Desinfetante D: iodóforo ${ }^{4}$. Produto com a seguinte composição:

Iodo $2,60 \%$

Veículo $100,00 \mathrm{~mL}$

Desinfetante F: Compostos fenólicos ${ }^{5}$. Produto com a seguinte composição:

Orto-fenilfeno $12,24 \mathrm{~g}$

Orto-benzil paraclorofenol. $11,08 \mathrm{~g}$

Para-terceário amilfeno. $4,12 \mathrm{~g}$

Veículo $.100,00 \mathrm{~mL}$

\subsection{SOLUÇÃO NEUTRALIZANTE}

Um caldo composto por meio de cultura TSB enriquecido com 5\% de soro de coelho estéril foi utilizado para neutralizar os desinfetantes. Este caldo foi inativado por 30 minutos a $56^{\circ} \mathrm{C}$ positivos, acrescido de $0,05 \% \mathrm{v} / \mathrm{v}$ de Tween $80^{6}$ (polioxietilensorbitano monooleato) para prevenir a formação de películas.

1 Água de lavadeira (Super Cândida ${ }^{8}$ )

2 Glutaraldeído da Reagentes analítcos Dinâmica®

3 Proxitane Alfa $\circledR$

4 Biocid $\circledR^{\circledR}$ laboratório Phizer

5 Poly-phen laboratório Lab-tek 


\subsection{DILUENTE}

Os desinfetantes foram diluídos em água de fonte ( $\mathrm{pH}$ em torno de 7) não tratada, bidestilada em equipamento de vidro, autoclavada a $120^{\circ} \mathrm{C}$ por 15 minutos e armazenada sob temperatura de refrigeração.

\subsection{TÉCNICA DE QUANTIFICAÇÃO DAS UNIDADES FORMADORAS DE COLÔNIAS (U.F.C.) PARA LEITURA DO CRESCIMENTO NO MEIO DE STONEBRINK}

As leituras nos tubos contendo o meio de Stonebrink, foram realizadas no $21^{\circ}$ e no $28^{\circ}$ dia após a semeadura. A área da superfície do meio de cultura foi demarcada contando-se 6 $\mathrm{cm}$ lineares a partir da extremidade inferior da superfície exposta, segundo o critério de leitura estabelecido por Pinheiro (2001):

0: Ausência de crescimento bacteriano

1: 0 a $20 \%$ da superfície demarcada

2: 21 a $40 \%$ da superfície demarcada

3: 41 a $60 \%$ da superfície demarcada

4: 61 a $80 \%$ da superfície demarcada (colônias quase confluentes)

5: 81 a 100\% da superfície demarcada (toda a superfície do meio tomada por colônias)

3.9 TÉCNICA DE QUANTIFICAÇÃO DAS UNIDADES FORMADORAS DE COLÔNIAS (U.F.C.) PARA LEITURA DO CRESCIMENTO NAS PLACAS DE CAMADA DELGADA DE MIDDLEBROOK 7H11 MODIFICADO (MARCONDES, 2002) 
As leituras das U.F.C. nas placas de camada delgada de Middlebrook 7H11 foram feitas no $5^{\circ}$ e $7^{\circ}$ dias após semeadura. A análise quantitativa das placas foi feita demarcandose cada placa com 49 quadrados de $0,5 \mathrm{~cm}$ cada lado (Figura 1); desses, dez foram escolhidos aleatoriamente para leitura. Optou-se pelo formato de "L" para facilitar o deslocamento da placa no microscópio optico ${ }^{7}$. As U.F.C. foram contadas nos 10 quadrados, e o resultado final foi calculado através da média aritmética destas contagens.

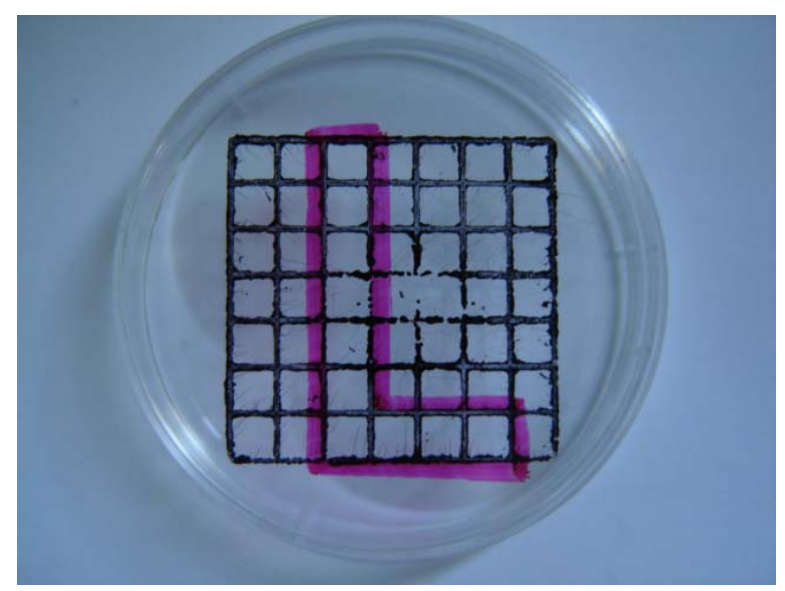

Figura 1 - Placa Petri quadriculada e área de leitura ("L") delimitada

\subsection{PROCEDIMENTOS EXPERIMENTAIS}

O inóculo utilizado foi uma suspensão de M.bovis a 0,06g/\%. A bactéria foi conservada em tubos com meio de Stonebrink e mantida em temperatura de $37^{\circ} \mathrm{C}$, com idade de cultivo de 32 dias. As colônias eram maceradas com ajuda de um pistilo e um cadinho estéreis em $1 \mathrm{~mL}$ de salina com $0,05 \%$ de Tween 80 , para facilitar a homogeneização do inóculo. O inóculo era então transferido para um frasco estéril do tipo "shot" com pérolas de vidro, adicionava-se os $99 \mathrm{~mL}$ restantes de solução salina $0,85 \%$, o frasco era agitado e as pérolas auxiliavam na homogeneização final do inóculo.

7 Microscópio CBA - Olympus - American Co 


\subsubsection{Delineamento experimental}

Inicialmente pilotos foram feitos para determinar a diluição das suspensões bacterianas de M.bovis ,os melhores tempos de leitura das placas com meio de cultura $7 \mathrm{H} 11$ e dos tubos com Stonebrink. Posteriormente, foram feitas dez repetições, utilizando-se as suspensões bacterianas padronizadas anteriormente, em que se avaliou o desempenho dos desinfetantes frente a estirpe de M.bovis isolada de caprinos e devidamente tipificada pelo PCR. Em cada repetição utilizou-se 24 placas de Petri de vidro estéreis de 9,5 cm de diâmetro, cada um delas com quatro círculos de papel filtro (carreador). Essas placas receberam $4 \mathrm{~mL}$ de suspensão bacteriana e foram então divididas em seis grupos com quatro placas cada. O grupo A, grupo controle, recebeu solução salina estéril $0,85 \%$; o grupo B correspondeu ao grupo testado com hipoclorito de sódio; o grupo C foi o grupo testado com glutaraldeído; o grupo D foi testado com a mistura de ácido peracético e peróxido de hidrogênio; o grupo E recebeu o iodóforo; e o grupo $\mathrm{F}$ foi testado com o produto a base de compostos fenólicos. Cada grupo foi dividido em dois lotes: um recebeu matéria orgânica ( $1 \mathrm{~mL}$ de soro de coelho estéril) e o outro recebeu o placebo ( $1 \mathrm{~mL}$ de solução salina estéril), portanto duas placas de cada grupo com matéria orgânica e duas placas sem matéria orgânica. Após a aplicação da suspensão bacteriana, da matéria orgânica e da solução salina, as placas foram armazenadas à temperatura ambiente $\left(21 \pm 2{ }^{\circ} \mathrm{C}\right)$ durante 30 minutos para que houvesse contato entre a suspensão e o papel filtro. Depois deste período, foram acrescidos os desinfetantes $(4 \mathrm{~mL})$ e a solução salina estéril (4 $\mathrm{mL}$ ). Metade das placas (duas placas por lote) foram mantidas à temperatura ambiente e as outras, à temperatura de $4^{\circ} \mathrm{C}$ por 60 minutos, tempo de ação dos desinfetantes. Em seguida , foram recolhidos três dos quatro círculos de papel de filtro por placa avaliada, os quais foram macerados em cadinho com auxílio de um pistilo (estéreis) com $10 \mathrm{~mL}$ da solução neutralizante estéril. Retirou-se então $1 \mathrm{~mL}$ desta solução para fazer uma nova diluição com 9 $\mathrm{mL}$ de água destilada estéril, e obteve-se assim uma suspensão a 1:100. Depois de concluída esta neutralização, as suspensões foram centrifugadas a $1000 \mathrm{G}$ durante 15 minutos, e o sedimento foi suspenso em $2 \mathrm{~mL}$ de solução salina $0,85 \%$ estéril. A partir das suspensões finais (obtidas de cada placa de cada lote e grupo) foram semeadas duas placas com meio de Middlebrook 7H11 modificado e dois tubos contendo meio de Stonebrink com $100 \mu \mathrm{L}$ cada (vide Fluxograma). 
3.10.2 Inoculação dos meios de cultura

As placas foram fechadas com fita adesiva Micropore ${ }^{\circledR}$ e incubadas em estufa a $37^{\circ} \mathrm{C}$, em condições de microaerofilia (Anexo C), dentro de caixas plásticas tipo "tuperware" contendo uma pastilha de Sonrisal ${ }^{\circledR}{ }^{8}$ numa placa de Petri aberta e um pedaço de palha de aço embebida em $5 \mathrm{~mL}$ de solução de sulfato de cobre numa outra placa aberta dentro do “tuperware”. A caixa foi vedada com filme plástico tipo Parafilme $\AA^{9}$. As leituras foram feitas todo quinto e sétimo dia após semeadura.

O meio de Stonebrink inoculado foi incubado horizontalmente a $37^{\circ} \mathrm{C}$ por 24 horas, até a obtenção da secagem da porção líquida. Transcorrido este período, os tubos tiveram as tampas bem fechadas; em seguida, foram incubados em posição horizontal a $37^{\circ} \mathrm{C}$ durante 21 dias, quando foi realizada a primeira leitura.

\subsection{TRATAMENTO ESTATÍSTICO}

Para realização da análise estatística, foram calculadas as médias das contagens, das duas duplicatas, das U.F.C. nas placas e dos escores nos tubos gerando os Apêndices C e D. O valor médio obtido foi transformado em percentual de redução gerando as tabelas 1 e 2 . Utilizou-se somente as leituras do segundo dia de leitura, que representaram os valores finais dos testes, obedecendo-se o critério descrito por Pinheiro (2001):

Média do controle $X$ (nas condições de temp e mo) = $100 \%$ de crescimento Média do desinfetante $\mathbf{Y}$ (nas mesmas condições de temp e mo) $=\mathbf{Y} \%$ crescimento $100-Y=\%$ de redução

Exemplificando:

Média de UFC, Repetição 1 (placa/controle $\left./ 4^{\circ} \mathrm{C} / \mathrm{smo}\right)=44,55$...... $.100 \%$ de crescimento

8 Alka Seltzer: Bayer do Brasil S.A.

9 Parafilm M: American natinal can TM - Chicago, IL 60631 
Média de UFC Repetição 1 ( placa/ glutaraldeído $\left./ 4^{\circ} \mathrm{C} / \mathrm{smo}\right)=0,00 \ldots \ldots .$. Y \%

$100-Y=\%$ de redução do desinfetante

$\mathbf{1 0 0 - 0 , 0 0}=\mathbf{1 0 0} \%$ de redução do desinfetante glutaraldeído na repetição 1.

A análise dos percentuais de redução foi efetuada com o auxílio dos softwares SPSS for Windows- Realese 9.01 (1999) e INSTAT 3.01 (1998). Foram feitos 8 gráficos (gráficos $1 \mathrm{a}$ 8) do tipo "boxplot" representando a ação dos desinfetantes nas diferentes condições testadas. Inicialmente os desinfetantes foram avaliados em conjunto, nas diferentes situações de temperatura e matéria orgânica, nesta etapa foi utilizado o teste de Kruskal-Wallis e o teste de Dunn como confirmatório. Adotou-se aqui um nível de confiança $\alpha=5 \%$ (vide apêndices $\mathrm{E}$ e F). Posteriormente, os percentuais de redução produzidos pelos diferentes desinfetantes foram avaliados em pares, frente as variáveis matéria orgânica (cmo e smo) e temperatura $\left(4^{\circ} \mathrm{C}\right.$ e ambiente) separadamente. Nesta etapa utilizou-se o teste de Mann-Wihtney. 


\subsection{FLUXOGRAMA}

A

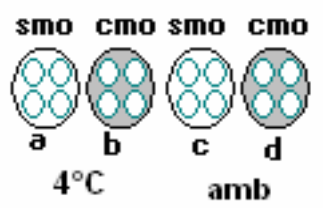

D

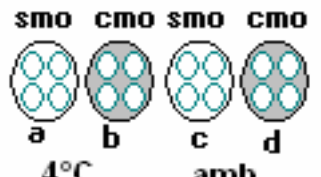

$4^{\circ} \mathrm{C}$
B

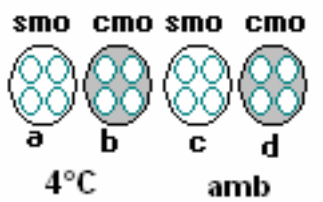

E

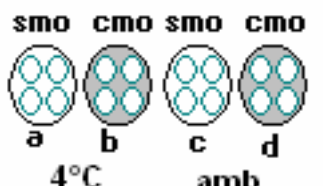

C

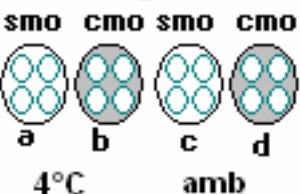

F

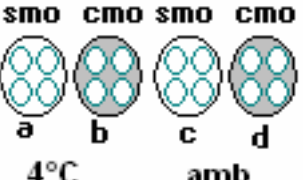

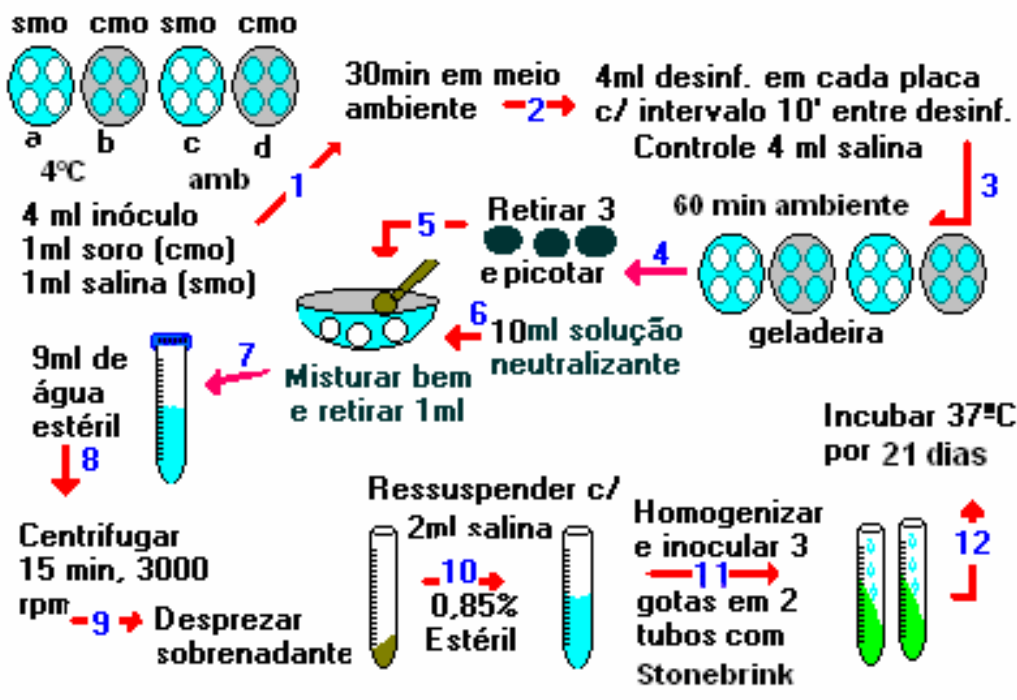

Princípios ativos:

A: grupo controle

B: hipoclorito de sódio

C: glutaraldeído

D: ácido peracético e peróxido de hidrogênio

E: iodóforo

F: composto fenólico

cmo: com matéria orgânica

smo: sem matéria orgânica

amb: temperatura ambiente $\left(20-22^{\circ} \mathrm{C}\right)$

$4{ }^{\circ} \mathrm{C}$ : temperatura de geladeira

7H11

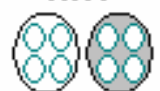

incubar à $37^{\circ} \mathrm{C}$ por 5 dias 
RESULTADOS 


\section{RESULTADOS}

Nas condições determinadas pelo presente estudo, houve crescimento da estirpe testada nas placas e tubos semeados. Nas placas, a melhor leitura de U.F.C de M. bovis foi obtida a partir do quinto dia pós-semeadura (p.s.) onde se pode quantificar e observar, com ajuda do microscópio óptico, o crescimento de colônias com aspecto rugoso, bordos irregulares e de coloração acastanhada (Figuras 1 e 2). Nos tubos, tal visualização e contagem só foi possível à partir do $21^{\circ}$ dia (Figuras 3 e 4$)$.

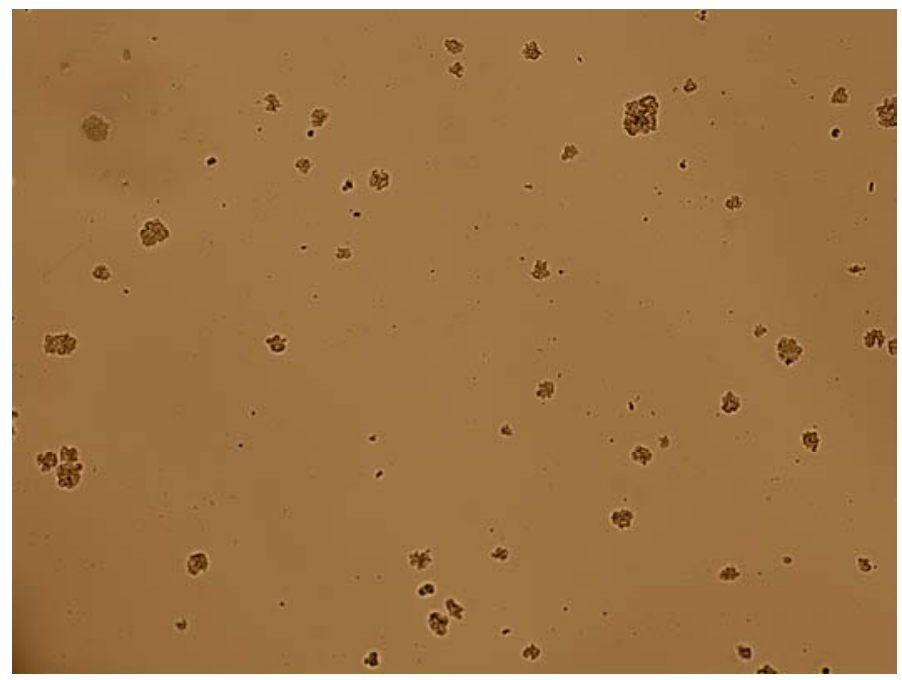

Figura 2- Colônias de M. bovis em placa com meio 7H11, com 7 dias de cultivo, microscopia óptica sob aumento de 100 x; grupo A (controle)

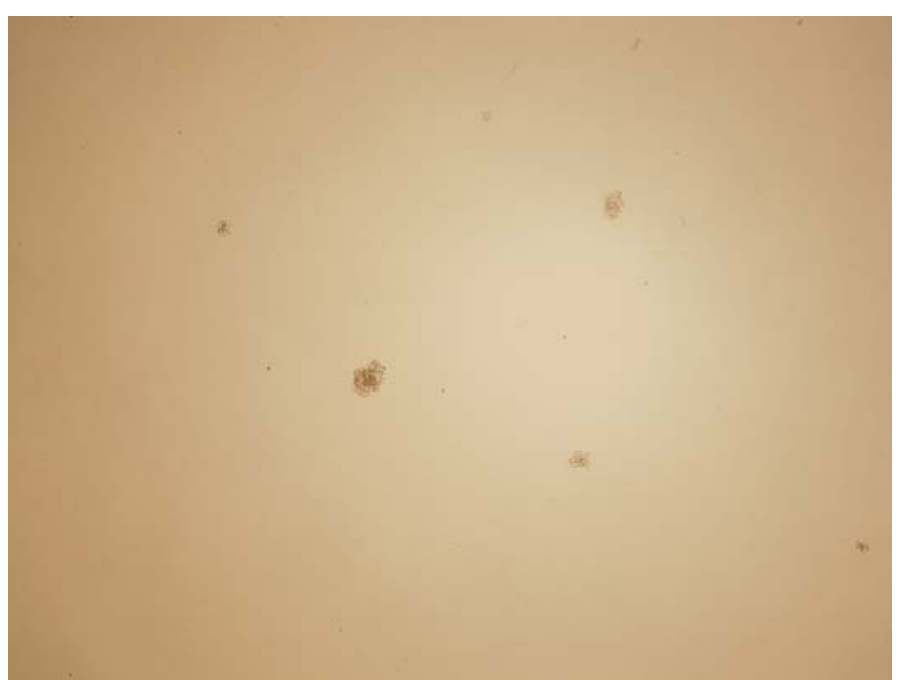

Figura 3- Colônias de M. bovis em placa com meio 7H11 ,com 7 dias de cultivo, microscopia óptica sob aumento de 100 x; grupo F (composto fenólico) 


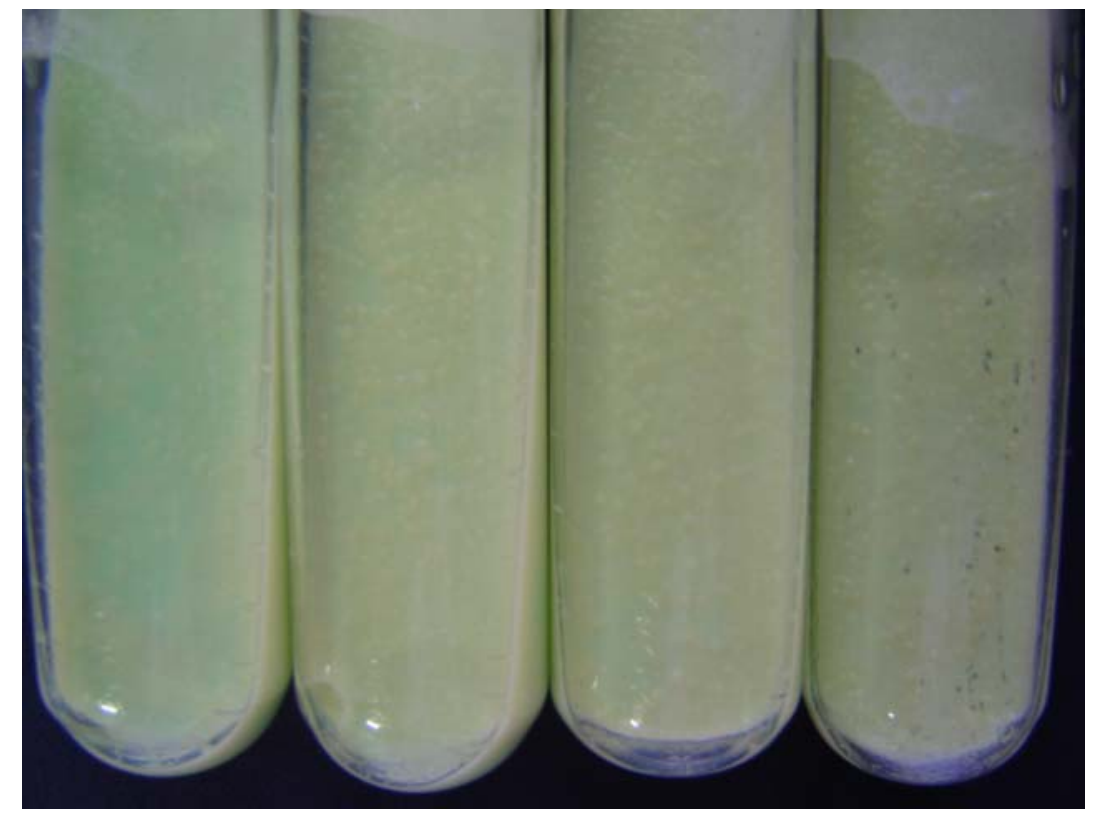

Figura 4 - Colônias de M.bovis do grupo E (iodóforo), com 21 dias de cultivo, em tubos com meio de Stonebrink

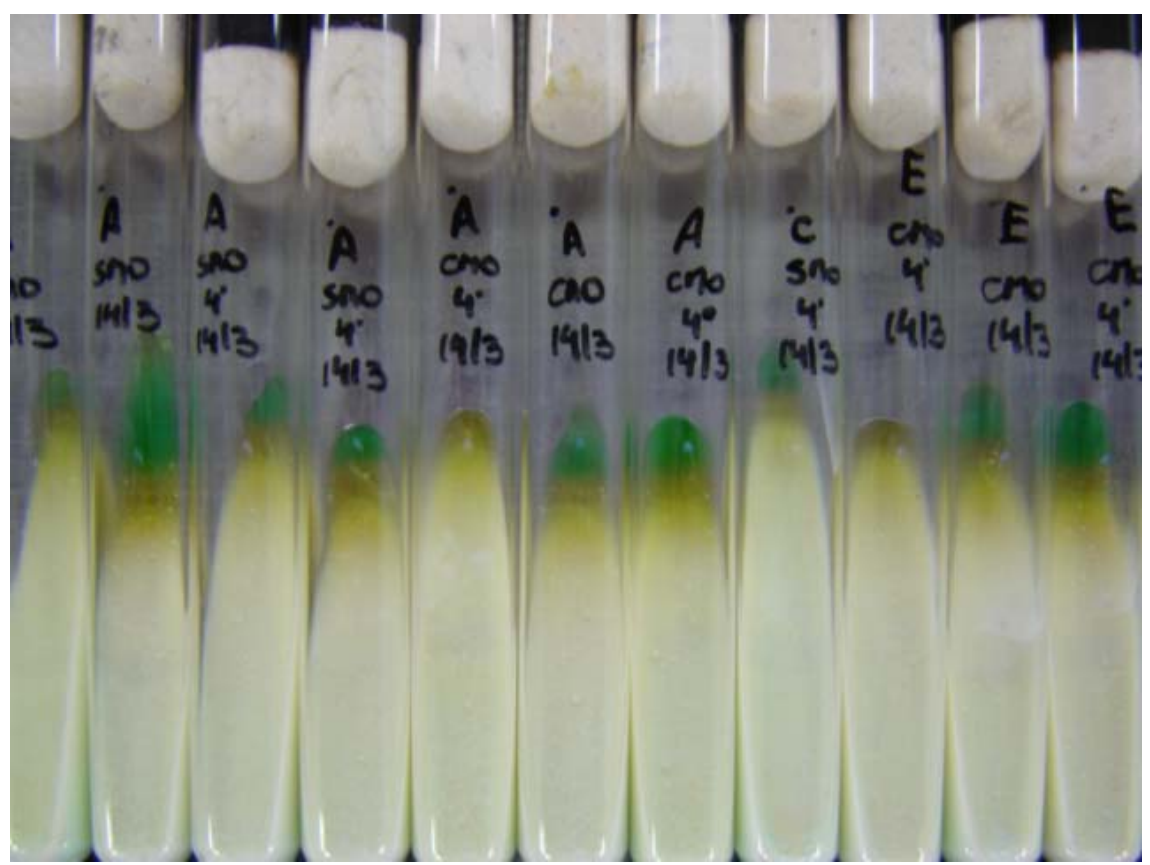

Figura 5- Colônias de M.bovis do grupo A (controle), com 28 dias de cultivo, em tubos com meio de Stonebrink 
As contagens das U.F.Cs nas placas com meio 7H11 estão descritas no Apêndice A, e os escores de crescimento das colônias nos tubos com Stonebrink estão dispostos no Apêndice B. A partir dessas contagens foram calculadas as médias das U.F.C. encontradas nas duas duplicatas, obtendo-se um único valor médio para cada dia de leitura nas dez repetições, essas médias estão relacionados no Apêndice C. O mesmo raciocínio vale para os valores de escore obtidos na leitura dos tubos (Apêndice B e D).

A partir das médias de contagens de U.F.C. em placas e dos escores em tubos foi calculado o percentual de redução obtido pelos desinfetantes nas duas técnicas gerando as tabelas 1 e 2 , as quais foram utilizadas para análise dos resultados.

\subsection{AVALIAÇÃO DO DESEMPENHO DOS DESINFETANTES NO TESTE EM PLACAS COM MEIO 7H11}

A avaliação da atividade micobactericida dos desinfetantes foi feita comparando-se os percentuais de redução de U.F.C., obtidos nas diferentes condições testadas, em relação ao valor correspondente observado no grupo controle, obedecendo às mesmas condições de temperatura, presença e ausência de matéria orgânica (mo). Os valores são apresentados nas tabelas 1 e 2, dados os quais originaram os gráficos 1 a 8 sendo que os gráficos 1 a 4 representam os testes efetuados em placas e os demais, os tubos. Nas placas onde houve contaminantes (vide Apêndice A) foi considerado o percentual obtido em sua duplicata para a elaboração da tabela 1.

Nas tabelas 1 e 2 pode-se verificar que houve casos em que o resultado obtido foi negativo, indicando que o controle teve crescimento inferior ao do teste, e o produto testado não teve ação micobactericida. Nesses casos o percentual de redução foi considerado como zero.

A visualização dos gráficos 1 a 4 revela que todos os produtos testados apresentaram atividade micobactericida. 
4.1.1 Avaliação da atividade micobactericida entre os desinfetantes na técnica em placas

A atividade micobactericida dos desinfetantes foi avaliada comparando-se $o$ desempenho dos mesmos entre si nas diferentes condições testadas (Teste de Mann-Whitney), obtendo-se os resultados descritos a seguir.

À temperatura ambiente, na ausência de mo (Gráfico 1), todos os produtos apresentaram atividades micobactericida iguais. Na presença de mo (Gráfico 2), os produtos B (hipoclorito), C (glutaraldeido), D (acido peracético) e F (composto fenólico) mantiveram o mesmo percentual de redução, já o produto $\mathbf{E}$ (iodóforo) apresentou pouca atividade micobactericida nessa condição, obtendo percentual de redução significativamente menor em relação aos demais desinfetantes.

À temperatura de $4^{\circ} \mathrm{C}$, na ausência de mo (Gráfico 3), todos os produtos apresentaram atividades micobactericida iguais $(100 \%)$ exceto pelo produto $\mathbf{C}$ que obteve percentual de redução significativamente menor em relação aos demais desinfetantes. O produto $\mathbf{D}$ manteve a mesma performance quando submetido à presença de mo, já os demais desinfetantes (Gráfico 4) tiveram sua atividade reduzida nessa condição. Os produtos B e D $\left(4^{\circ} \mathrm{C}\right.$; cmo) obtiveram percentagens de redução semelhantes e significativamente maiores em relação à $\mathbf{C}$, $\mathbf{E}$ e $\mathbf{F}$, que por sua vez apresentaram reduções semelhantes entre si.

4.1.2 Avaliação da atividade micobactericida dos desinfetantes frente à variável matéria orgânica na técnica em placas

A atividade micobactericida dos desinfetantes foi avaliada comparando-se o desempenho dos produtos frente a variável matéria orgânica (Teste de Mann-Whitney), obtendo-se os resultados descritos a seguir. 
À temperatura de $4{ }^{\circ} \mathrm{C}$, os produtos $\mathbf{B}, \mathbf{E}$ e $\mathbf{F}$ obtiveram percentuais de redução maiores na ausência de mo em relação aos percentuais na presença da mesma. Já os produtos $\mathbf{C}$ e $\mathbf{D}$ apresentaram percentuais de redução semelhantes em ambas as condições de presença e ausência de mo.

À temperatura ambiente, todos os produtos obtiveram percentuais de redução semelhantes em ambas as condições de presença e ausência de mo, exceto o produto $\mathbf{E}$ que apresentou percentual de redução maior na ausência de mo.

4.1.3 Avaliação da atividade micobactericida dos desinfetantes frente à variável temperatura na técnica em placas

A atividade micobactericida dos desinfetantes foi avaliada comparando-se o desempenho dos produtos frente à variável temperatura (Teste de Mann-Whitney), obtendo-se os resultados descritos a seguir.

Na presença de mo, os produtos $\mathbf{B}, \mathbf{C}$ e $\mathbf{F}$ obtiveram percentuais de redução maiores à temperatura ambiente em relação aos percentuais a $4^{\circ} \mathrm{C}$. Já os produtos $\mathbf{D}$ e $\mathbf{E}$ apresentaram percentuais de redução iguais em ambas as condições de temperatura.

$\mathrm{Na}$ ausência de mo, todos os produtos obtiveram percentuais de redução semelhantes em ambas as condições de temperatura, exceto o produto $\mathbf{C}$ que apresentou percentual de redução maior à temperatura ambiente.

\subsection{AVALIAÇÃO DO DESEMPENHO DOS DESINFETANTES NO TESTE EM TUBOS COM MEIO DE STONEBRINK}

Os resultados da ação micobactericida dos produtos químicos testados, nos tubos, frente à estirpe de $M$. bovis foram analisados e originaram os gráficos 5 a 8 . 
A visualização dos gráficos 5 a 8 revela que todos os desinfetantes químicos testados apresentaram atividade micobactericida.

4.2.1 Avaliação da atividade micobactericida entre os desinfetantes na técnica em tubos

A atividade micobactericida dos desinfetantes foi avaliada comparando-se o desempenho dos mesmos entre si na diferentes condições testadas (Teste de Mann-Whitney), obtendo-se os resultados descritos a seguir.

À temperatura ambiente, na ausência de mo (Gráfico 5), todos os produtos apresentaram atividades micobactericida semelhantes (próximas de 100\%). Na presença de mo (Gráfico 6), os produtos B (hipoclorito), C (glutaraldeido), D (acido peracético) e $\mathbf{F}$ (composto fenólico) mantiveram o mesmo percentual de redução, já o produto E (iodóforo) apresentou pouca atividade micobactericida nessa condição, obtendo percentual de redução significativamente menor em relação aos demais desinfetantes.

À temperatura de $4^{\circ} \mathrm{C}$, na ausência de mo (Gráfico 7), todos os produtos apresentaram atividades micobactericida semelhantes, exceto pelo produto $\mathbf{C}$ que obteve percentual de redução significativamente menor em relação aos demais desinfetantes. O produto $\mathbf{D}$ manteve a mesma performance quando submetido à presença de mo, já os demais desinfetantes (Gráfico 8) tiveram sua atividade reduzida nessa condição. Os produtos B e D $\left(4^{\circ} \mathrm{C}\right.$; cmo) obtiveram percentagens de redução semelhantes e significativamente maiores em relação à $\mathbf{C}$, $\mathbf{E}$ e $\mathbf{F}$, que por sua vez apresentaram reduções semelhantes entre si.

4.2.2 Avaliação da atividade micobactericida dos desinfetantes frente à variável matéria orgânica na técnica em tubos.

A atividade micobactericida dos desinfetantes foi avaliada comparando-se o desempenho dos produtos frente a variável matéria orgânica (Teste de Mann-Whitney), obtendo-se os resultados descritos a seguir. 
À temperatura de $4{ }^{\circ} \mathrm{C}$, os produtos $\mathbf{B}, \mathbf{E}$ e $\mathbf{F}$ obtiveram percentuais de redução maiores na ausência de mo em relação aos percentuais na presença da mesma. Já os produtos C e D apresentaram percentuais de redução semelhantes em ambas as condições de presença e ausência de mo.

À temperatura ambiente, todos os produtos obtiveram percentuais de redução iguais em ambas as condições de presença e ausência de mo, exceto o produto $\mathrm{E}$ que apresentou percentual de redução maior na ausência de mo.

4.2.3 Avaliação da atividade micobactericida dos desinfetantes frente à variável temperatura na técnica em tubos.

A atividade micobactericida dos desinfetantes foi avaliada comparando-se o desempenho dos produtos frente a variável temperatura (Teste de Mann-Whitney), obtendo-se os resultados descritos a seguir.

Na presença de mo, os produtos $\mathbf{B}, \mathbf{C}$ e $\mathbf{F}$ obtiveram percentuais de redução maiores à temperatura ambiente em relação aos percentuais à $4^{\circ} \mathrm{C}$. Já os produtos $\mathbf{D}$ e $\mathbf{E}$ apresentaram percentuais de redução semelhantes em ambas as condições de temperatura.

$\mathrm{Na}$ ausência de mo, todos os produtos apresentaram percentuais de redução semelhantes em ambas as condições de temperatura, exceto o produto $\mathbf{C}$ que apresentou percentual de redução maior à temperatura ambiente. 
Tabela 1 - Percentual de redução de crescimento de M.bovis em placas com 7H11, segundo o princípio ativo do desinfetante químico, a temperatura de contacto, presença ou ausência de matéria orgânica - São Paulo - 2007

\begin{tabular}{|c|c|c|c|c|c|c|c|c|c|c|c|c|c|c|c|c|c|c|c|c|c|}
\hline \multirow{3}{*}{$\mathrm{R}$} & \multirow{3}{*}{$\mathrm{L}$} & \multicolumn{4}{|c|}{ Hipoclorito de sódio } & \multicolumn{4}{|c|}{ Glutaraldeído } & \multicolumn{4}{|c|}{ Ácido peracético } & \multicolumn{4}{|c|}{ Iodóforo } & \multicolumn{4}{|c|}{ Fenol } \\
\hline & & \multicolumn{2}{|c|}{$4^{\circ} \mathrm{C}$} & \multicolumn{2}{|c|}{ TA } & \multicolumn{2}{|c|}{$4^{\circ} \mathrm{C}$} & \multicolumn{2}{|c|}{ TA } & \multicolumn{2}{|c|}{$4^{\circ} \mathrm{C}$} & \multicolumn{2}{|c|}{ TA } & \multicolumn{2}{|c|}{$4^{\circ} \mathrm{C}$} & \multicolumn{2}{|c|}{ TA } & \multicolumn{2}{|c|}{$4^{\circ} \mathrm{C}$} & \multicolumn{2}{|c|}{ TA } \\
\hline & & smo & cmo & smo & $\mathrm{cmo}$ & 10 & cmo & no & $\mathrm{cmo}$ & smo & $\mathrm{cmo}$ & mo & cmo & no & $\mathrm{cmo}$ & smo & $\mathrm{cmo}$ & mo & cmo & mo & $\mathrm{cmo}$ \\
\hline $1^{\mathrm{a}}$ & 2 & 100,0 & 100,0 & 100,0 & 100,0 & 100,0 & 100,0 & 100,0 & 100,0 & 100,0 & 100,0 & 100,0 & 100,0 & 100,0 & 91,0 & 100,0 & 100,0 & 100,0 & 98,4 & 100,0 & 100,0 \\
\hline $2^{a}$ & 2 & 100,0 & 100,0 & 100,0 & 100,0 & 100,0 & 100,0 & 100,0 & 100,0 & 100,0 & 100,0 & 100,0 & 100,0 & 100,0 & 21,1 & 100,0 & $-34,9$ & 100,0 & 58,9 & 100,0 & 100,0 \\
\hline $3^{a}$ & 2 & 0,0 & 100,0 & $\overline{00,0}$ & 100,0 & 98,4 & 89,4 & 00,0 & 100,0 & 100,0 & 100,0 & 100,0 & 100,0 & 100,0 & 3,6 & 100,0 & $-20,6$ & 100,0 & 92,7 & 100,0 & 100,0 \\
\hline $4^{a}$ & 2 & 0,0 & 98,6 & 100,0 & 100,0 & 80,9 & 97,9 & 00,0 & 89,9 & 100,0 & 100,0 & 100,0 & 100,0 & 100,0 & $-33,2$ & 100,0 & 34,8 & 100,0 & 93,1 & 100,0 & 100,0 \\
\hline $5^{a}$ & 2 & 00,0 & 100,0 & 100,0 & 100,0 & 86,8 & 89,1 & 100,0 & 100,0 & 100,0 & 100,0 & 100,0 & 100,0 & 100,0 & $-16,1$ & 100,0 & 7,4 & 100,0 & 94,8 & 100,0 & 100,0 \\
\hline $6^{\mathrm{a}}$ & 2 & 100,0 & 97,7 & 100,0 & 100,0 & 97,7 & 99,9 & 100,0 & 100,0 & 100,0 & 100,0 & 100,0 & 100,0 & 100,0 & 44,6 & 92,9 & 26,9 & 100,0 & 100,0 & 100,0 & 100,0 \\
\hline $7^{a}$ & 2 & 100,0 & 100,0 & 100,0 & 100,0 & 99,8 & 77,3 & 100,0 & 100,0 & 100,0 & 100,0 & 100,0 & 100,0 & 100,0 & $-15,0$ & 100,0 & $-75,1$ & 100,0 & 79,3 & 100,0 & 93,8 \\
\hline $8^{a}$ & 2 & 100,0 & 100,0 & 100,0 & 100,0 & 65,0 & 27,6 & 100,0 & 100,0 & 100,0 & 100,0 & 100,0 & 100,0 & 100,0 & $-20,4$ & 100,0 & $-10,4$ & 100,0 & 86,3 & 100,0 & 100,0 \\
\hline $9^{a}$ & 2 & 100,0 & 81,8 & 100,0 & 100,0 & 4,0 & 76,4 & 100,0 & 100,0 & 100,0 & 100,0 & 100,0 & 100,0 & 100,0 & 31,7 & 100,0 & 14,9 & 100,0 & 65,5 & 100,0 & 100,0 \\
\hline $10^{\mathrm{a}}$ & 2 & 100,0 & 89,0 & 100,0 & 100,0 & 65,1 & 45,2 & 99,5 & 98,9 & 100,0 & 100,0 & 100,0 & 100,0 & 100,0 & 29,3 & 100,0 & 6,4 & 100,0 & 90,7 & 100,0 & 100,0 \\
\hline
\end{tabular}

R Repetições

Ta Temperatura ambiente $\left(20^{\circ}\right.$ a $\left.22^{\circ} \mathrm{C}\right)$

L Leituras $\left(1^{\circ}\right.$ e $2^{\circ}$ dias $)$

SMO Ausência de matéria orgânica

$4^{\circ} \mathrm{C}$ Temperatura de 4 Graus Celsius CMO Presença de matéria orgânica 
Tabela 2 - Percentual de redução de crescimento de M.bovis na superfície do meio de Stonebrik em tubos, segundo o princípio ativo do desinfetante químico, a temperatura de contacto e presença ou ausência de matéria orgânica - São Paulo - 2007

\begin{tabular}{|c|c|c|c|c|c|c|c|c|c|c|c|c|c|c|c|c|c|c|c|c|c|}
\hline \multirow{3}{*}{$\mathrm{R}$} & \multirow{3}{*}{$\mathrm{L}$} & \multicolumn{4}{|c|}{ Hipoclorito de sódio } & \multicolumn{4}{|c|}{ Glutaraldeído } & \multicolumn{4}{|c|}{ Ácido peracético } & \multicolumn{4}{|c|}{ Iodóforo } & \multicolumn{4}{|c|}{ Fenol } \\
\hline & & \multicolumn{2}{|c|}{$4^{\circ} \mathrm{C}$} & \multicolumn{2}{|c|}{ TA } & \multicolumn{2}{|c|}{$4^{\circ} \mathrm{C}$} & \multicolumn{2}{|c|}{ TA } & \multicolumn{2}{|c|}{$4^{\circ} \mathrm{C}$} & \multicolumn{2}{|c|}{ TA } & \multicolumn{2}{|c|}{$4^{\circ} \mathrm{C}$} & \multicolumn{2}{|c|}{ TA } & \multicolumn{2}{|c|}{$4^{\circ} \mathrm{C}$} & \multicolumn{2}{|c|}{ TA } \\
\hline & & smo & $\mathrm{cmo}$ & smo & $\mathrm{cmo}$ & smo & $\mathrm{cmo}$ & smo & $\mathrm{cmo}$ & smo & $\mathrm{cmo}$ & smo & $\mathrm{cmo}$ & smo & $\mathrm{cmo}$ & smo & $\mathrm{cmo}$ & smo & $\mathrm{cmo}$ & smo & $\mathrm{cmo}$ \\
\hline $1^{\mathrm{a}}$ & 2 & 100,0 & 100,0 & 100,0 & 100,0 & 40,0 & 75,0 & 100,0 & 100,0 & 100,0 & 100,0 & 100,0 & 100,0 & 100,0 & $-100,0$ & 100,0 & 83,3 & 100,0 & 0,0 & 100,0 & 100,0 \\
\hline $2^{\mathrm{a}}$ & 2 & $\overline{00,0}$ & 100,0 & 100,0 & 100,0 & 75,0 & 100,0 & 100,0 & 100,0 & 100,0 & 100,0 & 100,0 & 100,0 & 87,5 & $-50,0$ & 100,0 & $-11,1$ & 100,0 & 16,7 & 100,0 & 100,0 \\
\hline $3^{a}$ & 2 & 0,0 & 100,0 & 0,0 & 100,0 & 71,4 & 33,3 & 0,0 & 100,0 & 0 & 0,0 & 100,0 & 10 & 0 & $-16,7$ & 85,7 & 25,0 & 10 & 33,3 & 100,0 & 100,0 \\
\hline $4^{a}$ & 2 & 0,0 & 71,4 & 100,0 & 100,0 & $-12,5$ & 71,4 & 00,0 & 100,0 & 100,0 & 100,0 & 100,0 & 100,0 & 00,0 & 2,9 & 100,0 & 0,0 & $\overline{0,0}$ & 42,9 & 100,0 & $\overline{0,0}$ \\
\hline $5^{a}$ & 2 & $\overline{00,0}$ & 100,0 & 100,0 & 100,0 & 28,6 & 77,8 & 100,0 & 100,0 & 100,0 & 100,0 & 100,0 & 100,0 & 100,0 & 11,1 & 100,0 & 37,5 & 100,0 & 55,6 & 100,0 & 100,0 \\
\hline $6^{\mathrm{a}}$ & 2 & 100,0 & 60,0 & 100,0 & 100,0 & 60,0 & 60,0 & 100,0 & 100,0 & 100,0 & 100,0 & 100,0 & 100,0 & 90,0 & 20,0 & 50,0 & 11,1 & 100,0 & 80,0 & 100,0 & 100,0 \\
\hline $7^{\mathrm{a}}$ & 2 & 100,0 & 100,0 & 100,0 & 100,0 & 100,0 & 33,3 & 100,0 & 100,0 & 100,0 & 100,0 & 100,0 & 100,0 & 83,3 & $-33,3$ & 100,0 & $-33,3$ & 100,0 & 33,3 & 100,0 & 83,3 \\
\hline $8^{\mathrm{a}}$ & 2 & 100,0 & 88,9 & 100,0 & 100,0 & 0,0 & 11,1 & 100,0 & 100,0 & 100,0 & 100,0 & 100,0 & 100,0 & 100,0 & 11,1 & 100,0 & $-25,0$ & 100,0 & 55,6 & 100,0 & 100,0 \\
\hline $9^{a}$ & 2 & 100,0 & 33,3 & 100,0 & 100,0 & $-11,1$ & 11,1 & 55,6 & 55,6 & 100,0 & \begin{tabular}{|l|}
100,0 \\
\end{tabular} & 100,0 & 100,0 & 100,0 & $-11,1$ & 100,0 & $-11,1$ & 100,0 & 11,1 & 100,0 & 55,6 \\
\hline $10^{\mathrm{a}}$ & 2 & 100,0 & 40,0 & 100,0 & 77,8 & 10,0 & 20,0 & 60,0 & 55,6 & 100,0 & 100,0 & 100,0 & 100,0 & 80,0 & 0,0 & 100,0 & $-11,1$ & 100,0 & 40,0 & 100,0 & 100,0 \\
\hline
\end{tabular}

R Repetições

Ta Temperatura ambiente $\left(20^{\circ}\right.$ a $\left.22^{\circ} \mathrm{C}\right)$

L Leituras $\left(1^{\circ}\right.$ e $2^{\circ}$ dias) SMO Ausência de matéria orgânica

$4^{\circ} \mathrm{C}$ Temperatura de 4 Graus Celsius $\quad \mathrm{CMO}$ Presença de matéria orgânica 


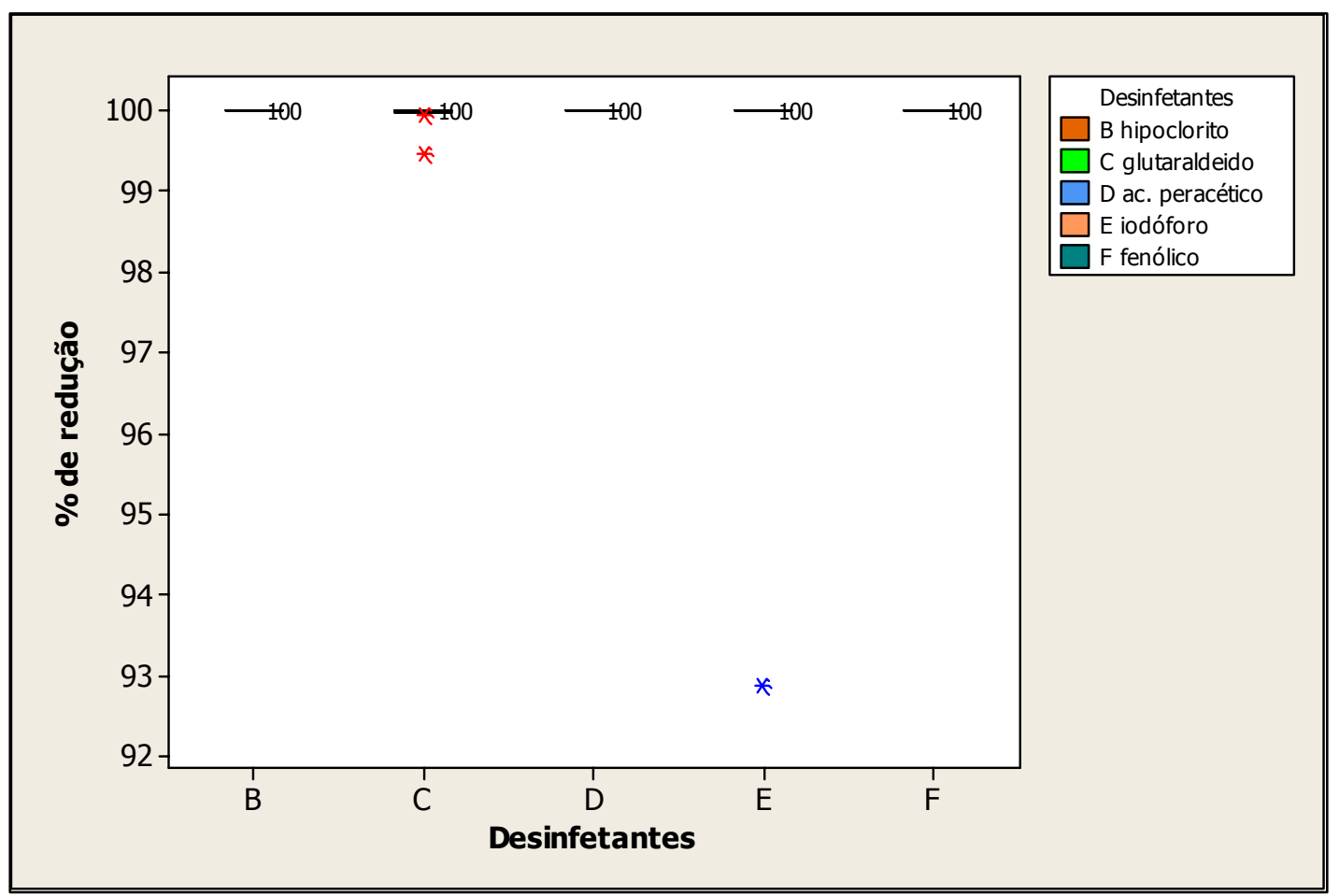

Gráfico 1- Atividade micobactericida dos desinfetantes em placas com meio 7H11 na temperatura ambiente e ausência de matéria orgânica

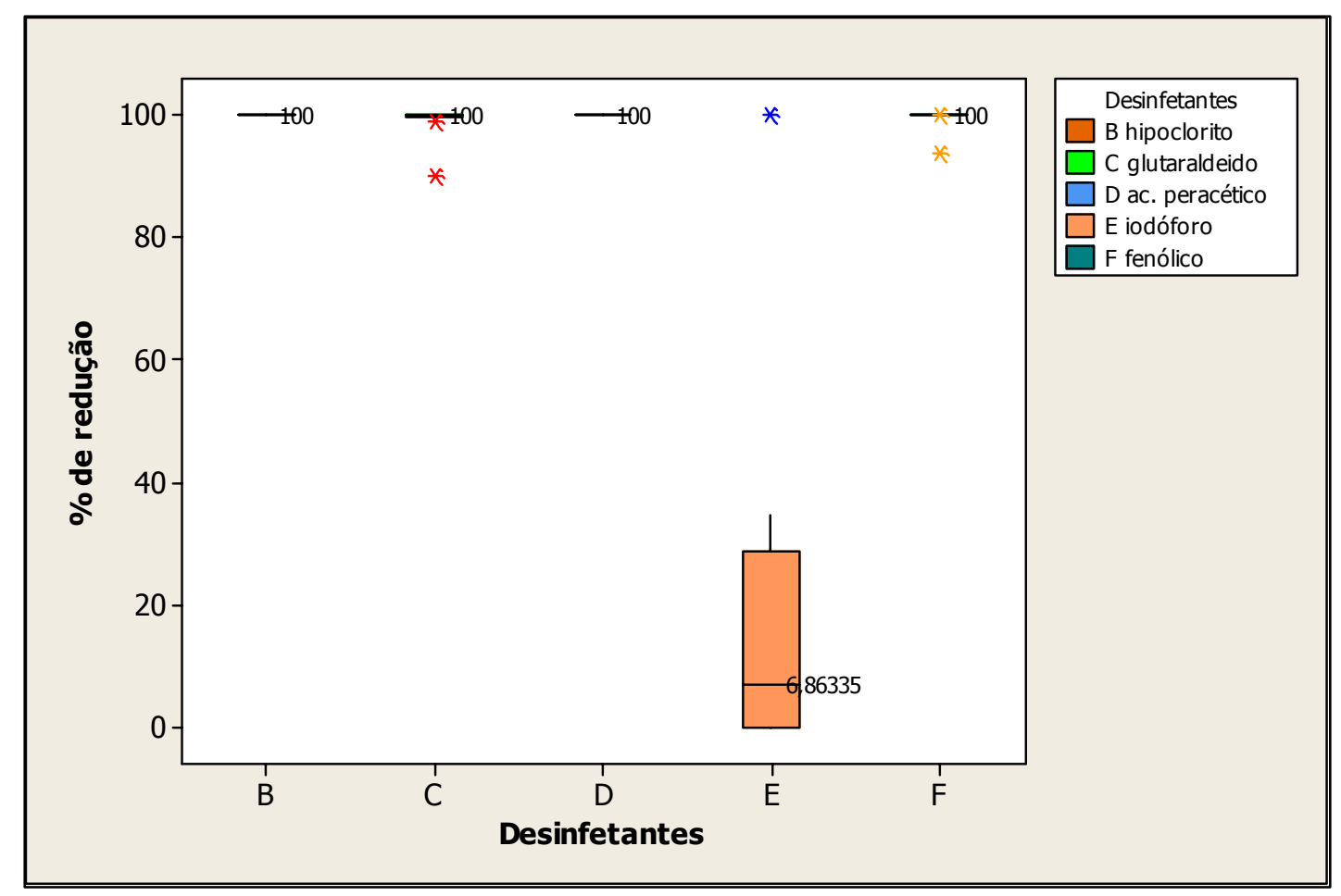

Gráfico 2- Atividade micobactericida dos desinfetantes em placas com meio 7H11 na temperatura ambiente e presença de matéria orgânica 


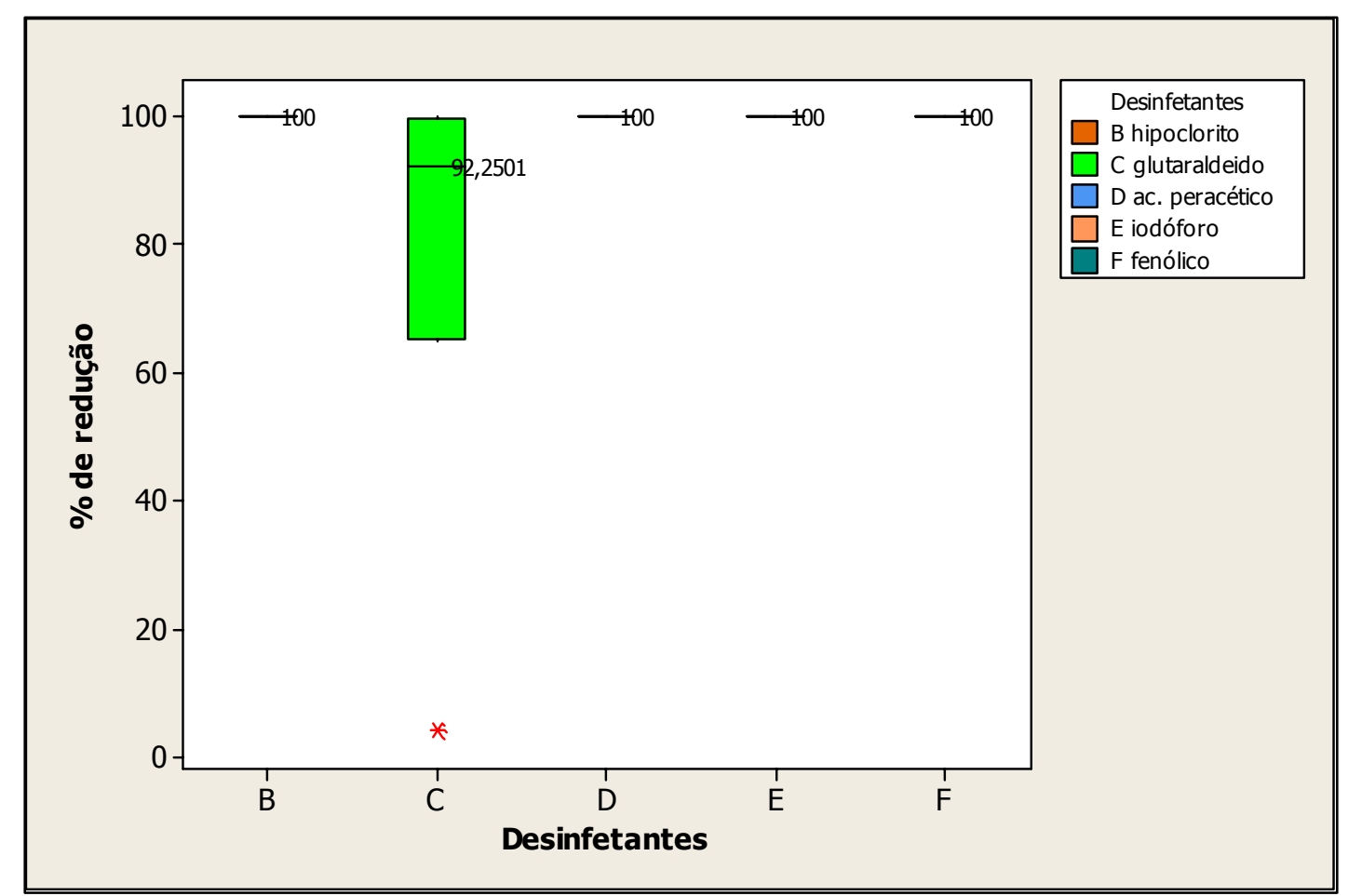

Gráfico 3- Atividade micobactericida dos desinfetantes em placas com meio 7H11 na temperatura de $4{ }^{\circ} \mathrm{C}$ e ausência de matéria orgânica

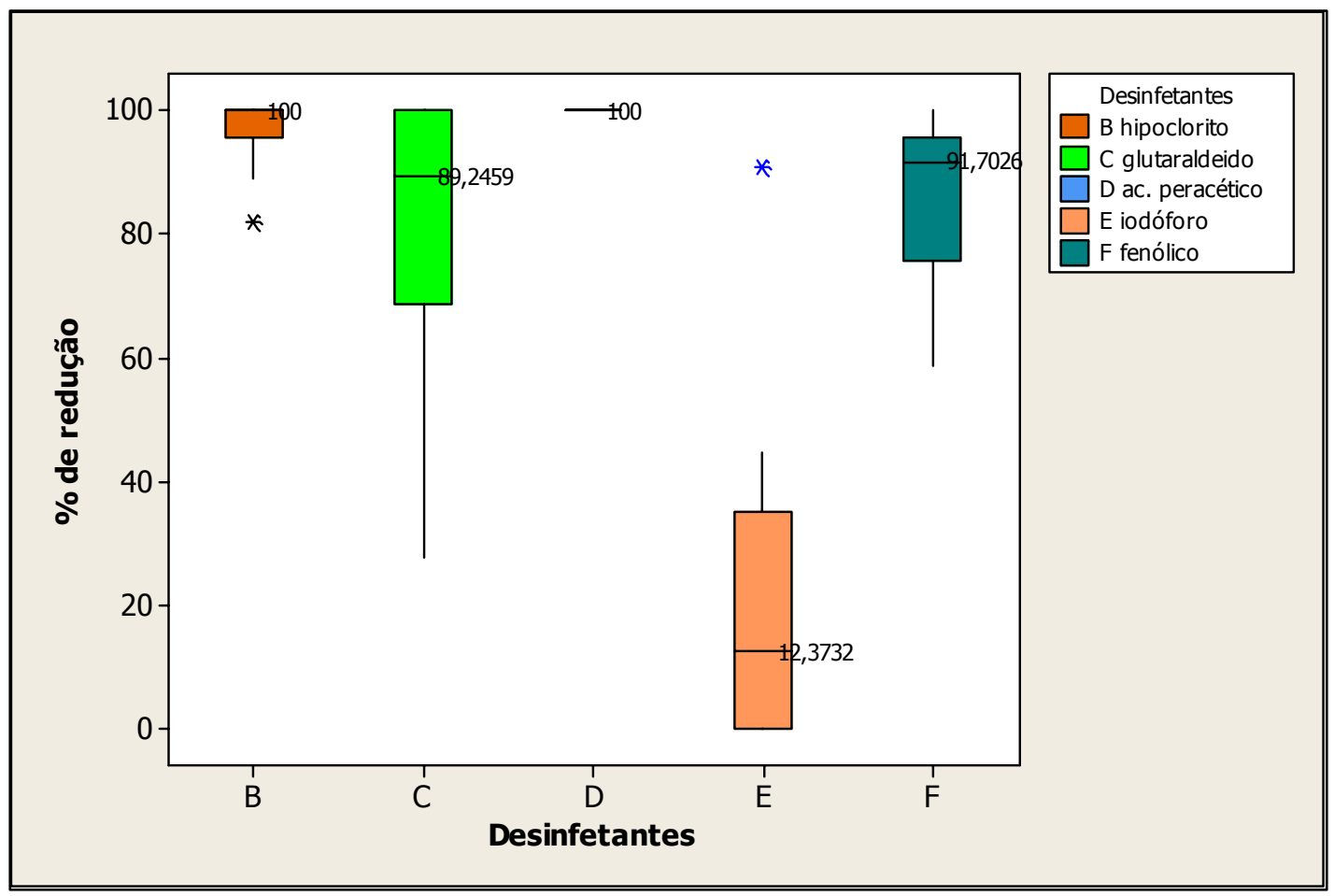

Gráfico 4- Atividade micobactericida dos desinfetantes em placas com meio 7H11 na temperatura de $4{ }^{\circ} \mathrm{C}$ e presença de matéria orgânica 


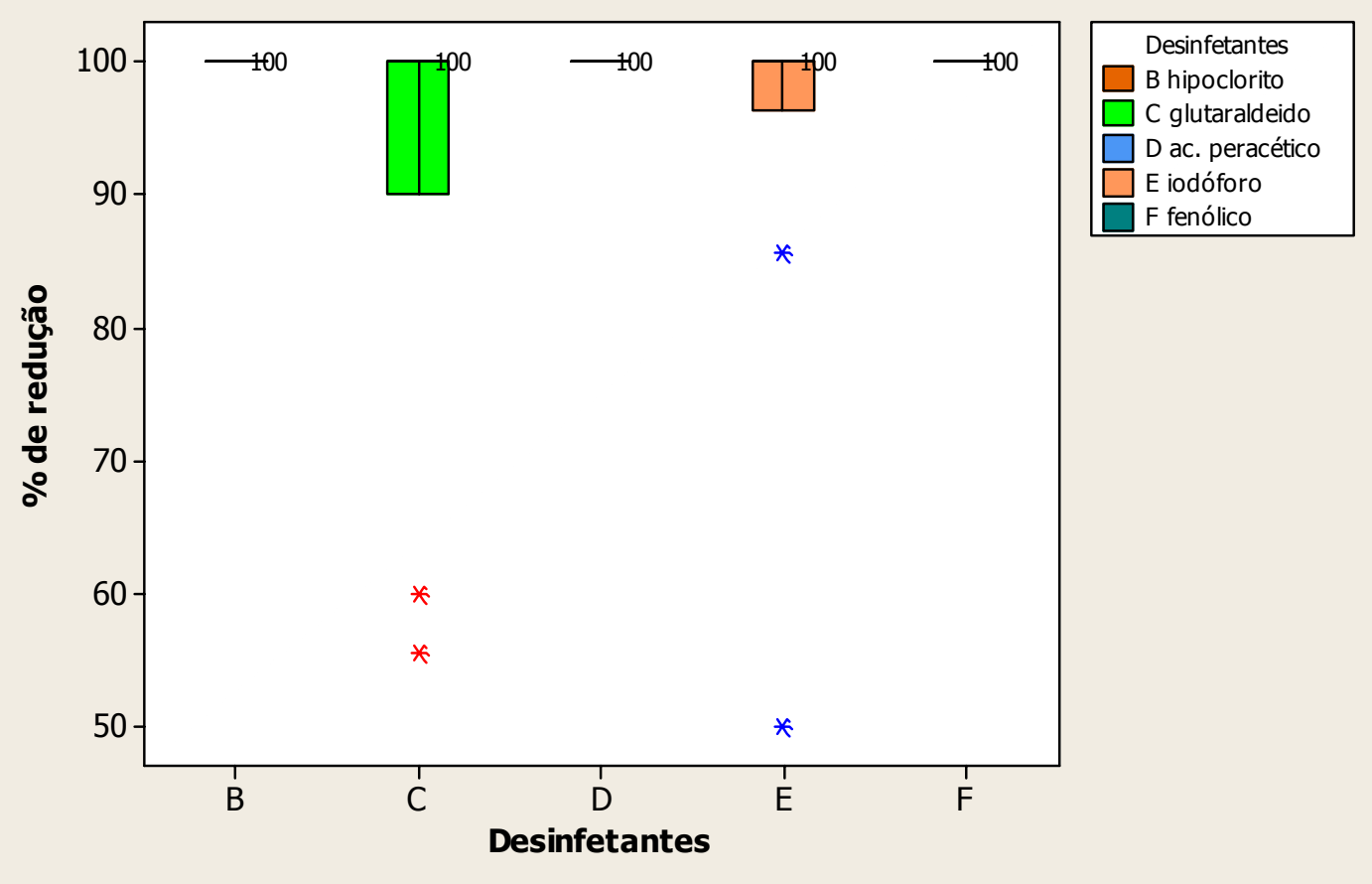

Gráfico 5- Atividade micobactericida dos desinfetantes em tubos com meio de Stonebrink na temperatura ambiente e ausência de matéria orgânica

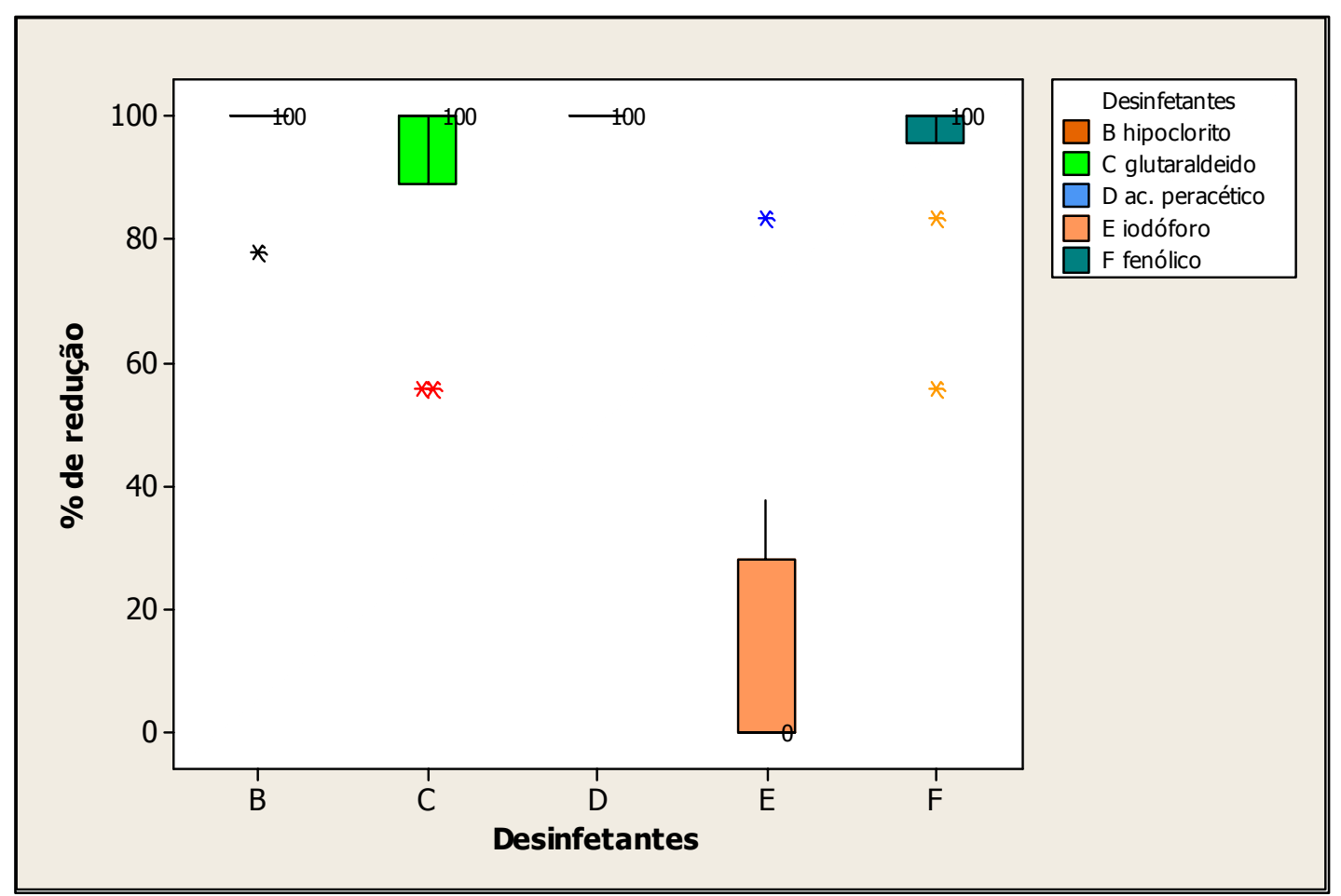

Gráfico 6- Atividade micobactericida dos desinfetantes em tubos com meio de Stonebrink na temperatura ambiente e presença de matéria orgânica 


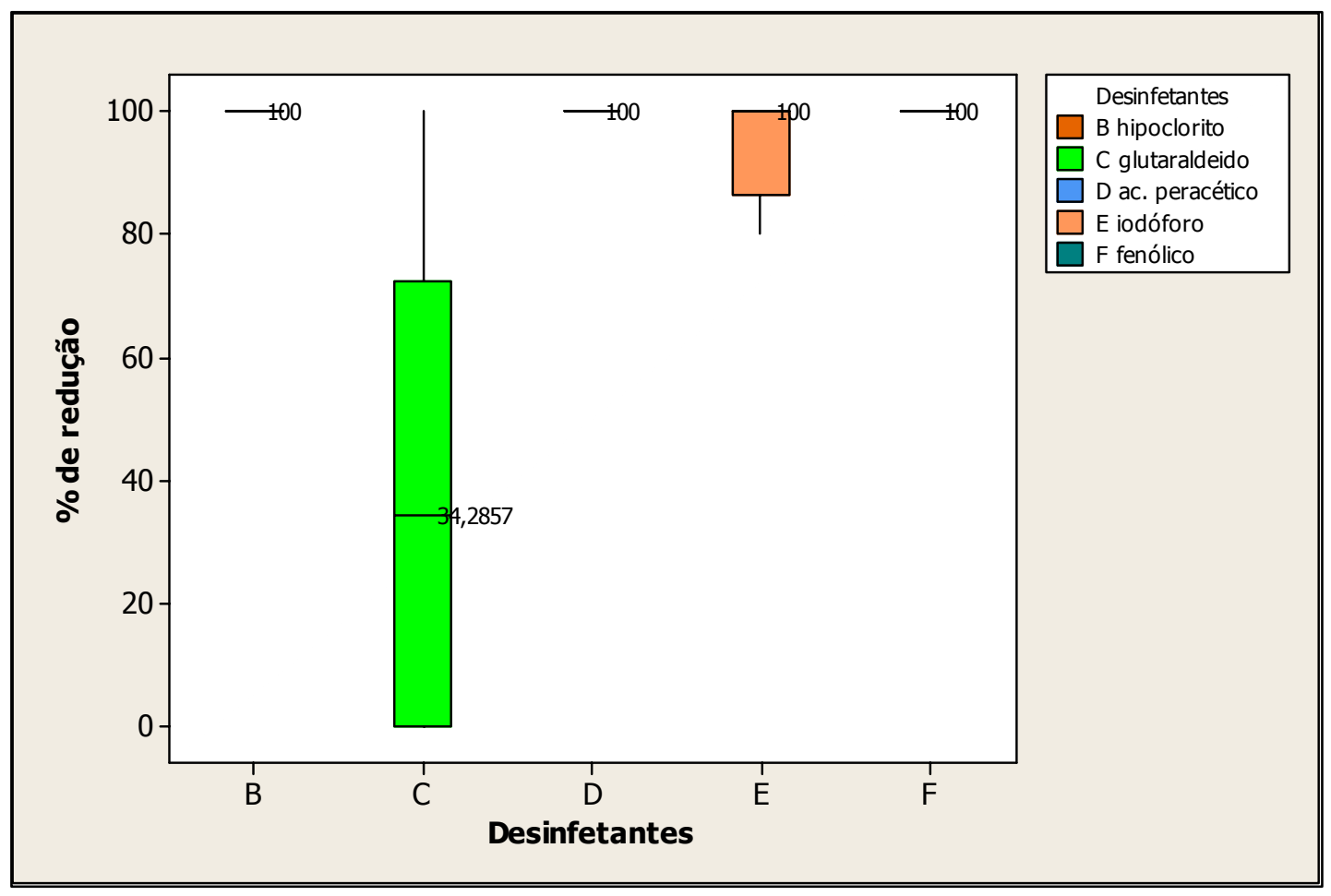

Gráfico 7- Atividade micobactericida dos desinfetantes em tubos com meio de Stonebrink na temperatura de $4{ }^{\circ} \mathrm{C}$ e ausência de matéria orgânica

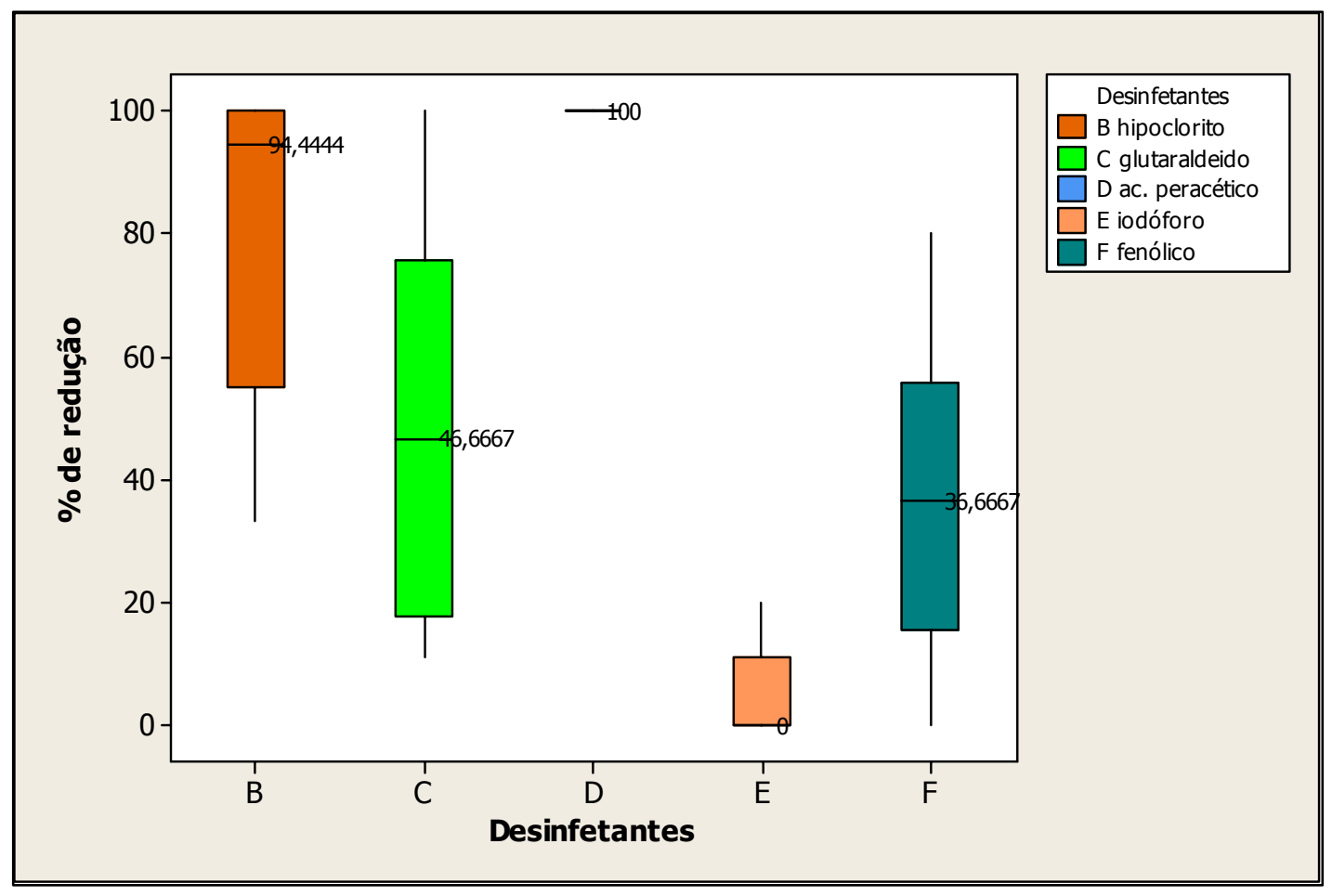

Gráfico 8- Atividade micobactericida dos desinfetantes em tubos com meio de Stonebrink na temperatura de $4{ }^{\circ} \mathrm{C}$ e presença de matéria orgânica 
DISCUSSÃO 


\section{DISCUSSÃO}

A visualização microscópica do crescimento de colônias (M. bovis) com aspecto rugoso, bordos irregulares e de coloração acastanhada, obtidos no meio de cultura de Middlebrook 7H11 a partir do quinto dia pós-semeadura (p.s) (Figuras 1 e 2) também foi observado por Marcondes (2002) que, trabalhando com a estirpe padrão $M$. bovis (AN5) constatou que as colônias podiam ser melhores visualizadas a partir do $5^{\circ}$ e $6^{\circ}$ dia p.s. A morfologia inicial e aspecto das bordas das colônias também foram observados sendo coincidentes com a morfologia encontrada neste estudo embora as cepas sejam oriundas de espécies diferentes.

As repetições do teste de desinfetantes realizado em placas, com meio 7H11, puderam ser efetuadas em aproximadamente sete dias, entretanto, o tempo de execução das etapas realizadas nos tubos foi de 28 dias. A variável "tempo de execução" foi avaliada por Marcondes (2002) que comparou o tempo de crescimento nas placas e nos tubos, demonstrando que o método de cultivo em placas possibilita a realização de leitura em menor tempo e o possível estabelecimento de uma identificação prelimimar da micobactéria isolada, baseando-se nas características morfológicas das colônias.

Durmaz et al. (1985), Welch et al. (1993), Idigoras et al. (1995), Mejia et al. (1999) e Somoskovi e Magyar (1999) também demonstraram as vantagens do diagnóstico da técnica de camada delgada frente ao método tradicional de cultivo em meios de Löwenstein- Jensen e Stonebrink relatando significativa redução no tempo para a observação das primeiras colônias com elevada sensibilidade em favor da técnica de camada delgada.

A contagem precisa em menor período de tempo é um aspecto que valoriza o teste realizado em placas (MARCONDES, 2002; MARCONDES et al., 2006; DIB, 2005; DIB et al., 2006), pois a visualização tardia de colônias em meios de cultura tradicionais é um fator que limita a recomendação dos testes que avaliam a atividade micobactericida de desinfetantes químicos (PINHEIRO et al., 1992, PINHEIRO et al., 1997; PINHEIRO, 2001). Dib (2005) observou que a visualização das U.F.C. das estirpes de M. bovis foi facilitada nas 
placas quando comparada aos tubos, e concluiu que o meio de Middlebrook 7H11 modificado, por ser transparente, permite a observação das colônias ao microscópio.

Pinheiro (1990), portanto, concluiu que experimentos visando o aperfeiçoamento do método microbiológico convencional para um rápido diagnóstico representam uma grande vantagem na luta contra a tuberculose no homem e nos animais (SCHABERG et. al. 1995; MEJIA et. al., 1999).

O teste em tubos foi realizado para permitir comparação dos resultados da performance dos produtos químicos avaliados com a técnica em placas, entretanto a técnica desenvolvida por Pinheiro (1990) tem o fator "tempo" como uma ressalva a ser feita, levandose em conta que há a limitação de no mínimo quatro meses (PINHEIRO, 1994) para que todas as repetições necessárias, para validar estatisticamente o teste, sejam efetuadas.

A leitura das U.F.C. de M. bovis efetuada nos tubos (Tabela 2 e Figuras 3 e 4) foram realizadas à partir do $21^{\circ}$ dia, terminando no 28 dia p.s. Esta condição de tempo foi adaptada dos trabalhos de Pinheiro (1994) onde se ressalta a necessidade de padronização do tempo de leitura diante da velocidade de crescimento da estirpe testada. Marcondes (2002) obteve crescimento em $74,2 \%$ dos tubos semeados com M.bovis a partir do $14^{\circ}$ dia, e de cerca de $99 \%$ no $21^{\circ}$ dia. Dib (2005) observou crescimento nos tubos semeados com M. bovis à partir do $21^{\circ}$ dia de cultivo, com grande maioria dos tubos apresentando crescimento aos 28 dias p.s; Koneman et al. (2001) citaram o tempo médio de crescimento de amostras de campo como sendo de 24 a 40 dias. Córner e Nicolapoulos (1998) utilizando estirpes de M. bovis (AN5) e M. bovis (M86/90) em diversos meios de cultura, entre eles o Stonebrink e o Middlebrook 7H11, obtiveram como médias de crescimento 27,3 (AN5) e 28 dias (M86/90) no meio de Middlebrook fazendo leitura sem auxilio de microscópio. No meio de Stonebrink as médias foram 32,8 (AN5) e 30,6 dias (M86/90).

Pinheiro (1994) recomendou que, os ensaios confirmatórios para a avaliação da atividade micobactericida dos desinfetantes químicos fossem executados com amostras de $M$. bovis recém isoladas de tecidos animais. O teste realizado com estirpes submetidas a 
sucessivos repiques pode apresentar resultado diferente da amostra recém isolada (ZIEGLER; GRÄTSCH, 1987; PINHEIRO, 1994).

No presente estudo, os testes foram efetuados utilizando o M. bovis recém isolado de caprinos, isto é, com poucas passagens em meios de cultura. A variação de resistência aos desinfetantes químicos entre estirpes de micobactérias utilizadas como microrganismos teste já foi relatada por Croshaw (1971), Russel (1982), Lind et al. (1986), e Best et al (1990) que consideraram o M. tuberculosis mais resistente aos desinfetantes do que o M. bovis e o $M$. smegmatis. Pinheiro (2001) trabalhando com quatro estirpes de M. avium observou diferenças de resistência entre elas.

Tendo em vista que, um dos objetivos deste trabalho era o de recomendar produtos químicos de eficácia comprovada, optou-se pela reavaliação dos grupos de desinfetantes já testados, em diferentes micobactérias, por Pinheiro et al. $(1992,1997)$ e Pinheiro (2001) incluindo dois diferentes princípios ativos.

A atividade micobactericida dos produtos escolhidos já foi relatada: aldeídos (BORICK et al., 1964; SNYDER; CHEATLE, 1965; PINHEIRO, 1990; PINHEIRO, 1994); clorados (COSTIGAN, 1936; SMITH, 1971; PINHEIRO, 1990; CASTILLO GUERRERO, 1991); ácido peracético (LYNAM et al., 1995; HERNANDEZ et al., 2003a; HERNANDEZ et al., 2003b); iodóforos (KNAYSI,1932; GERSHENFELD et al., 1954) e compostos fenólicos (BERGAN; LISTAD, 1971; McDONNELL; RUSSELL, 1999).

Em relação aos produtos testados contra a estirpe de $M$. bovis, observou-se que todos apresentaram atividade micobactericida nas duas técnicas (placas e tubos) efetuadas, confirmando as recomendações de uso dos desinfetantes (WORLD HEALTH ORGANIZATION, 1984).

Os percentuais de redução descritos nas tabelas 1 e 2, e visualizados nos gráficos 1 a 8 , favorecem a compreensão dos valores obtidos, uma vez que trabalha considerando o percentual de redução do produto quando comparado com o seu respectivo grupo controle. Tal recurso foi preconizado por Pinheiro (1990, 1994, 2001). 
À temperatura ambiente, nas condições de presença e ausência de matéria orgânica, os melhores resultados nas placas e nos tubos foram obtidos pelos produtos B (hipoclorito), $\mathbf{C}$ (glutaraldeido), D (acido peracético) e F (composto fenólico) (Gráficos 1, 2, 5 e 6). A boa atividade micobactericida dos clorados, aldeídos e compostos fenólicos foi descrita por Pinheiro et al. (1992) e Pinheiro (1997); a do acido peracético por Hernandez et al. (2003a) e Hernandez et al. (2003b).

O desempenho do produto E foi prejudicado pela presença de mo nas duas condições de temperatura testadas, concordando com a interferência desta variável sobre os iodóforos, descrita por Gélinas e Goulet (1983), WORLD HEALTH ORGANIZATION (1984) e Pinheiro (1990). Segundo Zanon, (1973), os iodóforos podem ter o seu potencial oxidante consumido pelo excesso de material orgânico, antes que ocorra a destruição microbiana.

$\mathrm{Na}$ condição de temperatura de $4^{\circ} \mathrm{C}$ e ausência de mo, nas placas e nos tubos (Gráficos 3 e 7), os produtos $\mathbf{B}$ (hipoclorito), $\mathbf{D}$ (acido peracético), $\mathbf{E}$ (iodóforo) e $\mathbf{F}$ (composto fenólico) apresentaram atividades micobactericida superiores à $80 \%$ de redução, performance esta que foi mantida pelo produto $\mathbf{D}$ quando submetido à presença de mo, já os demais desinfetantes (Gráfico 4) tiveram sua atividade reduzida nessas condições $\left(4^{\circ} \mathrm{C}, \mathrm{cmo}\right)$.

A diminiução da atividade micobactericida do hipoclorito de sódio na presença de mo já foi relatada por Hekmati e Bradley, (1979), Gélinas e Goulet (1983), Pinheiro (1990), Castillo Guerrero (1991) e Pinheiro $(1994,2001)$. Além disso, o efeito da temperatura sobre os produtos clorados foi demonstrado por Costigan (1936) e Dychdala (1983), os quais constataram que o aumento da temperatura ocasionou um aumento da atividade bactericida do desinfetante, concordando com os resultados obtidos neste experimento, onde o produto B teve queda no desempenho à $4^{\circ} \mathrm{C}$ e presença de mo.

$\mathrm{O}$ produto $\mathbf{F}$ apresentou boa atividade micobactericida, concordando com relatos de Bergan e Lystad (1971), mas também teve sua atividade diminuída na presença de mo e temperatura de $4^{\circ} \mathrm{C}$, discordando da indicação desse produto para ambientes com alto teor de matéria orgânica (SPAULDING et. al., 1977; PRINDLE, 1983). 
Borick; Dondershine e Chandler (1964), WORLD HEALTH ORGANIZATION (1984) e Pinheiro et al. (1992,1997) descreveram o efeito micobactericida dos aldeídos, concordando com os resultados obtidos neste experimento. Deve-se ressaltar entretanto que o glutaraldeido, neste estudo, teve sua atividade micobactericida significativamente diminuída à temperatura de $4^{\circ} \mathrm{C}$, resultando em atividade inferior a dos compostos fenólicos, o que também foi observado por Pinheiro 2001. Em contra partida, Scott e Gorman (1983), observaram redução na atividade do glutaraldeido quando utilizado em pH 8 e condições de elevada temperatura ambiente $\left(32^{\circ} \mathrm{C}\right)$. Confirmando-se, portanto, que a temperatura em que são conduzidos os ensaios de avaliação da atividade micobactericida dos desinfetantes químicos, pode interferir nos resultados obtidos (TILLEY, 1942; PINHEIRO, 1994).

O ácido peracético (produto D) apresentou atividade micobactericida em todas as condições testadas de temperaturas e presença e ausência de mo. Hernandez (2003b) observou atividade micobactericida no ácido peracético (0,26\%) em 20 minutos de ação contra estirpes de M. tuberculosis, M.avium-intracellurare, M.fortuitum e M. chelonae. Lynam et al. (1995), constatou que um produto com $0,35 \%$ de ácido peracético e $0,96 \%$ de peróxido de hidrogênio foi bem mais efetivo contra vários tipos de micobactérias quando comparado ao glutaraldeído $2 \%$.

O produto $\mathbf{D}$ apresentou o melhor desempenho micobactericida em todas as condições testadas, seguido pelo produto $\mathbf{B}$ (exceto condição de $4^{\circ} \mathrm{C}$; cmo), produto $\mathbf{F}$ (exceto condição de $4^{\circ} \mathrm{C}$; cmo), produto $\mathbf{C}$ (exceto condição de $4^{\circ} \mathrm{C}$; smo e cmo) e produto $\mathbf{E}$ (exceto condição de ta e $4^{\circ} \mathrm{C}$; cmo).

$\mathrm{Na}$ avaliação da performance, obtida pelos produtos testados, a seqüência de melhores desempenhos foi a mesma nas duas técnicas (tubos e placas), confirmando a possibilidade de se utilizar a técnica em placas com meio 7H11 para o teste de desinfetantes. 
CONCLUSÕES 


\section{CONCLUSÕES}

Os resultados obtidos nas condições em que o presente estudo foi realizado oferecem as seguintes conclusões:

- A técnica de cultivo de micobactérias em camada delgada no meio de Middlebrook 7H11 permitiu uma visualização precoce das micobactérias e se mostrou viável para realização de testes de desinfetantes

- Os cinco tipos de desinfetantes analisados apresentaram atividade micobactericida

- O melhor desempenho foi obtido pelo ácido peracético seguido pelo hipoclorito de sódio

- A atividade micobactericida dos iodóforos foi insatisfatória na presença de matéria orgânica 
REFERÊNCIAS 


\section{REFERÊNCIAS $^{1}$}

ABRAHÃO, R. M. C. M. Tuberculose humana causada pelo Mycobacterium bovis: considerações gerais e a importância dos reservatórios animais. f. 1-25; 90-137. Tese (Mestrado em Saúde Pública) - Faculdade de Saúde Pública, Universidade de São Paulo, São Paulo, 1998.

ACHA, P.N.; SZYFRES, B. Zoonosis y enfermedades transmisibles comunes al hombre y a los animales. 2. ed. Washington: Organización científica. Panamericana de la Salud, 1986. p. 174-185. (Publicacíon científica, 503).

ALTERTHUM, F. Relatório sobre a atividade do Lysoform Primo. Rev. Ped. Prat, v. 48, n. 5/6, p.75-77, 1977.

ASCENZI, J. M. Glutaraldehyde-based disinfectants. In: ASCENZI, J. M. (Ed.). Handbook of disinfectants and antiseptics. New York, N.Y.: Marcel Dekker, 1996. p. 11-32.

ASSOCIATION FRANÇAISE DE NORMALIZATION (AFNOR). Détermination de la l'activite bactéricide (méthode par diluition - neutralisation). Paris, 1977. p. 72-150.

ASSOCIATION OF OFFICIAL ANALYTICAL CHEMISTS (AOAC). Official methods of analysis. 15. ed. Arlington. 1990. p. 142-143.

AYLIFFE, G. A. J.; COARES, D.; HOFFMAN, P. N. Chemical disinfection in hospitals. 2. ed. London: Public Health Laboratory, 1993.

BERGAN, T.; LYSTAD, A. Antitubercular action of desinfectants. Journal applied Bacteriology, v. 34, n.4, p. 751-756, 1971.

BERNABÉ, A.; GÓMEZ, M. A.; NAVARRO, J. A.; GÓMEZ, S.; SÁNCHEZ, J.;

SIDRACH, J.; MENCHEN, V.; VERA, A.; SIERRA, M. A. Morphopathology of caprine tubreculosis. I. Pulmonary Tuberculosis. Anales de veterinaria de Murcia, v. 6/7, p. 9-20, 1990-1991.

\footnotetext{
${ }^{1}$ Conforme as diretrizes para a apresentação de dissertações e teses. 4. ed. São Paulo; FMVZ-USP.
} 
BENESI, F. J.; PINHEIRO, S. R.; MAIORKA, P. C; BENITES, N. R.; BIRGEL JR., E. H.; GREGORY, L. Tuberculosis in goat in Brazil: case report apresentado no World Buiatrics Congress, Nice (France), 2006.PS2-050

BEST, M.; SATTAR, S. A.; SPRINGTHORPE, V. S.; KENNEDY, M. E. Efficacies of selected disinfectants against Mycobacterium tuberculosis. Journal of Clinical Microbiology, v. 28, n. 10, p. 2234-2239, 1990.

BIER, O. Microbiologia e imunologia. 24. ed. São Paulo: Melhoramentos, 1985. p.149-170.

$\mathrm{BLOCK}^{1}$, S. S. Desinfection, sterilization and preservation. 3. ed. Philadelphia: Lea \& Fegiber, p. 874, 1983.

BLOOD, D.C.; HENDERSON, J. A. Clínica veterinária. 5. ed. Rio de Janeiro, Guanabara Koogan, 1983. p. 512-523.

BORICK, P. M. Chemical sterilizer (chemosterilizers). Advances Applied Microbiology, v.10, p.291-312, 1968.

BORICK, P. M.; DONDERSHINE, F. H.; CHANDLER, V. L. Alkalinized glutaraldehyde, a new antimicrobial agent. Journal of Pharmacology Science, v. 53, p. 1273-1275, 1964.

CARSON, L. A.; PETERSEN, N. J.; FAVERO, M. S.; AGUERO, S. M. Growth characteristics of atypical mycobacteria in water and their comparative resistance to disinfectants. Applied Environmental Microbiology, v. 36, n. 6, p. 839-846, 1978.

CASTILLO GUERRERO, A. Determinação da concentração ótima do hipoclorito de sódio para destruir Mycobacterium fortuitum em presença de quantidades variáveis de fezes de bovino como fonte de matéria orgânica., 1991. f. 47. Tese (Mestrado) - Faculdade de Medicina Veterinária e Zooctecnia da Universidade de São Paulo. São Paulo, 1991.

CASTILlO GUERRERO, A.; PINHEIRO, S. R.; MORAIS, Z. M.; VASCONCELlOS, S. A.; ITO, F. H.; FERREIRA NETO, J. S. influência da matéria orgânica na atividade micobactericida do hipoclorito de sódio comercial com $2,5 \%$ de cloro ativo. Brasilian Journal Veterinary Research and Animal Science, São Paulo, v. 30, p. 211-216, 1993. Suplemento.

\footnotetext{
${ }^{1}$ KRONING, B.; PAUL, T. L. Di chemischen grundlagen von der giftwirkung und disinfection. Z. Hyg. Insekt., 25, 1/112, 1897.
} 
CENTRO PANAMERICANO DE ZOONOSIS. Bacteriologia de la tuberculosis humana y animal. Buenos Aires. Buenos Aires: 1988, Organización Panamericana de la Salud. v. 11, 63 p. Serie de Monografias Científicas y Técnicas;

COLLINS, F. M.; MONTALBINE, V. Mycobactericidal activity of glutaraldehyde solutions. Journal of clinical Microbiology, v. 4, n. 5, p. 408-412, 1976.

COLLINS, F. M. Bactericidal activity of alkaline glutaraldehyde solution agains a number of atypical mycobacterial species. Journal of applied Bacteriology, n. 61. p. 247-251, 1986.

CORNER, L. A.; NICOLACOPOULOS, C. Comparison of media used for the primary isolation of Mycobacterium bovis by veterinary and medical diagnostic laboratories. Australian veterinary Journal, v. 65, n. 7, p. 202-204, July, 1988.

COSIVI O.; GRANJE, J. M.; DABORN, C. J.; RAVIGLIONE, M.C.; FUGIKURA, T.; COUSINS, D.; ROBINSON, R.A.; HUCHZERMEYER, H. F. A. K.; KANTOR, I.; MESLIN, F. X.; Zoonotic tuberculosis due to Mycobacterium bovis in developing countries. Emerging Infectious Diseases, v. 4, n. 1, 1998.

COSTIGAN, S. M. Effectiveness of hot hypochlorite of low alkalinity in destroying M. tuberculosis. Journal of Bacteriology., n. 32, p. 57-63, 1936.

CROSHAW, B. The destruction of mycobacteria. In: HUGO, W. B.., ed. Inhibition and destruction of the microbial cell. London: Academic Press, 1971. p. 419-449.

CROSHAW, B. Disinfectant testing. In: COLlinS, C. H.; ALlOWOOD, D. M. C.; BLOOMFIELD, S. F.; FOX, A., Ed. Disinfectants their use and evaluation of effectiveness. New York: Academic Press, 1981. (Society for Applied Bacteriology technical series, 16).

DEUTSCHE GESELLSCHAFT FUR HYGIENE UND MIKROBIOLOGIE. Richtlimen fur die Prufung chemischer Disinfektions mittel. Stutgard, Gustav-Fisher, 1972.

DIB, C. C. Utilização de uma técnica rápida para isolamento de Mycobacterium bovis a partir de amostras de leite experimentalmente inoculadas. 2002. $115 \mathrm{f}$. Tese (Mestrado em Epidemiologia Experimental e Aplicada às Zoonoses)- Faculdade de Medicina Veterinária e Zootecnia, Universidade de São Paulo, São Paulo, 2005. 
DIB, C. C.; MORAIS, Z. M.; SOUZA, G. O.; AMAKU, M.; BENITES, N. R.; PINHEIRO, S.R. Utilização de uma técnica rápida para o diagnóstico de Mycobacterium bovis em amostras de leite experimentalmente inoculadas. Arquivos do Instituto Biológico, v. 73, n. 2, p. 149-155, 2006.

DURMAZ, R.; DURMAZ, B.; GUREL, M. Mycobacterium tuberculosis culture in Mycobacterium 7H11 agar versus Lowenstein-Jensen medium. Turkey, Mikrobiyoloji Bulteni, v. 19, n. 2, p. 88-94, 1985.

DYCHDALA, G. R. Chlorine and chlorine compounds. In: BLOCK, S. S., (Ed.) Disinfection, sterilization and preservation. 3. ed. Philafelphia: Lea \& Febiger, 1983. p. 157-182.

FREITAS, J. A.; PANETTA, J. C.; CURCIO, M.; UEKI, S. Y. M. Isolamento de cepas de Mycobacterium avium em búfalos abatidos para consumo. Revista de Saúde Pública, v. 35, n. 3, p. 315-317, 2001.

FUNDAÇÃO OSWALDO CRUZ. INSTITUTO NACIONAL DE CONTROLE DE QUALIDADE EM SAÚDE. Técnicas para o controle de qualidade: avaliação da atividade antibacteriana de saneantes domissanitários. Rio de Janeiro: 1985. (Manual técnico, 4).

GAGLIARDI,G. Igiene zootecnica. Bologna: Edizione Calderini, 165p. 1985.

GÉLINAS, P.; GOULET, J.; Neutralization of the activity of eight disinfectants by organic matter. Journal of Applied Bacteriology, n. 54, p. 243-247, 1983.

GÉLINAS, P.; GOULET, J.; TATAYRE, G.M.; PICARD, G.A. Effect of temperature and contact time on the activity of eight disinfectants: a classification. Journal of Food Protection, v. 47, November, p. 841-847, 1984.

GERSHENFELD, L.; FLAGG, W.; WITLIN, B. Iodine as a tuberculocidal agent. Military Surgeon, v. 114, n. 3, p.172-183, 1954.

GONTIJO FILHO,P.P., ROMÃO, C.M.C.P.A. Testes microbiológicos e antissépticos junto a Secretaria Nacional de Vigilância Sanitária. Revista de Microbiologia, v.2,n. 17,p. 143-147, 1986. 
GRIFFITH, A. S. Tuberculosis of the domesticated species of animals. Journal of Comparative Pathology, v. 41, p. 109-127, 1928.

HEKMATI, M.; BRADLEY, R. L. Effect of milk constituents on the persistence of sodium hypochlorite sanitizer. Journal of Dairy Science, n. 62, p. 47-48, 1979.

HERNANDEZ, A. C.; ESTRADA, A. V. Efectividad del formaldehido a diferentes concentraciones y temperaturas em lãs desinfecciones profilacticas. Cien.Tec.Agric.Vet., v. 6, p.111-122, 1984.

HERNÁNDEZ, A.; MARTRÓ, E.; MATAS, L.; AUSINA, V.; In vitro evaluation of Perafase ${ }^{\circledR}$ compared with $2 \%$ alkaline glutaraldehyde against Mycobaterium spp. Journal of hospital infection, v. 54, p. 52-56, $2003 \mathrm{a}$.

HERNÁNDEZ, A.; MARTRÓ, E.; MATAS, L.; BURGUÉS, C.; VASQUEZ, N.; CASTELLA, J.; AUSINA, V. In vitro evaluation of Perafase ${ }^{\circledR}$ compared with Cidex ${ }^{\circledR}$ in fibreoptic bronchoscope disinfection. Journal of hospital infection, v. 54, p. 46-51, $2003 \mathrm{~b}$.

HERNÁNDEZ, A.; MARTRÓ, E.; MATAS, L.; JIMENEZ, A.; AUSINA, V. Mycobactericidal and tuberculocidal activity of Korsolex® AF, an amine detergent/disinfectant product. Journal of hospital infection.; v. 59, p. 62-66, 2005.

HOLTON, J.; SHETTY, N.; MCDONALD V.; Efficacy of "Nu-Cidex" (0,35\% peracetic acid) against mycobacteria cryptosporidia. Journal of hospital infection.; v. 31, p. 235-237, 1995.

HUGO, W. B. The mode of action of antibacterial agents. Journal of applied Bacteriology., v. 30, n. 1, p. 17-50, 1967.

HUGO, W.B. Disinfection mechanisms. In: RUSSEL, A.D.; HUGO, W.B.; AYLIFFE, G. A. $\mathrm{J}$, (Ed.) Principles and practice of disinfection, preservation and sterilization. London Blackwell, 1982.p.158-185.

HURTADO, A.; VERA, A. Comparacíon de la efectividad del formaldehído a temperatura ambiente y a 70 grados Celsio em la desinfeccíon de unidades pecuárias. Revista cubana de ciências veterinarias, v. 17, n. 1-2, p.39-46, 1986.

IDIGORAS. P.; PÉREZ-TRALLERO, E.; ALCORTA, M.; GUTIÉRREZ, C.; MUÑOZBAROJA, I. Rapid detection of tuberculous and non-tuberculous Mycobacteria by 
microscopic observation of growth on Middlebrook 7H11 agar. European Journal of Clinical Microbiology Infectious Diseases, Spain, v. 14, n. 1, p.6-10, 1995.

ITO, F. E.; ENRIQUEZ-ROZAS, C. E.; VASCONCELlOS, S. A.; GUERREIRO, J.; CÔRTES, J. A. Ação desinfetante de alguns produtos comerciais sobre o vírus tipo "C" Waldmann da febre aftosa. Revista da Faculdade de Medicina Veterinária e Zootecnia, Universidade de São Paulo, v. 15, p. 69 -74, 1978.

JONES, L. M.; BOOTH, N. H.; MCDONALD, L. E. Farmacologia e terapêutica em Veterinária. 4.ed. Rio de Janeiro: Guanabara Koogan, 1983. p. 620-643.

KANTOR, I. N.; RITACCO, V. Bovine tuberculosis in latin america and the caribbean: current status, control and eradication programs. Veterinary Microbiology, v. 40, n. 1/4, p. 5 - 14, 1994.

KLEEBERG, H. H. Tuberculosis humana de origen bovino y salud pública, Rev. Cient. techn. Offic. Int. Epizzot., v. 3, p. 55-76, 1984.

KNAYSI, G. The toxicity of iodine for the cells of Mycobacterium tuberculosis. Journal of infectious Diseases, v. 50, p. 253, 1932.

KONEMAN, E. W.; ALLEN, S. D.; LANDA, W. M.; SCHRECKENBERGER, P. C.; WINN JUNIOR, W. C. Micobactérias. In: Diagnóstico Microbiológico - Texto e Atlas colorido. 5. ed. Rio de Janeiro: Editora Medsi, 2001, p. 903 - 963.

KOSTENBAUDER, H. B. Physical factors influencing the activity of antimicrobial agents. In: BLOCK, S. S., (Ed). Disinfection, sterilization and preservation. 3. ed. Philadelphia: Lea \& Febiger, 1983, p. 811-828.

LEERS, W. D. Disinfection fibreoptic endoscopes: how not transmit Mycobacterium tuberculosis by bronchoscopy. Journal Canadian Medical Association, v. 123, n. 4, p. 275 $280,1980$.

LIÉBANA, E.; ARANAZ, A.; URQUIA, J. J.; MATEOS, A.; DOMINGUEZ, L. Evaluation of the gamma-interferon assay for erradication of tuberculosis in goat herd. Australian Veterinary Journal, v. 76, n.1, p.50-53, 1998. 
LIND, A.; LUNDHOLM, M.; PEDERSEN, G.; SUNDAEUS, V.; WÄHLÉN, P. A carrier method for the assessment of the effectiveness of disinfectants against Mycobacterium tuberculosis. Journal of hospital infection, v. 7, n. 1, p. 60-67, 1986.

LINTON, A. H.; HUGO, W. B.; RUSSELL, A.D. (Ed.) Disinfection in veterinary and farm animal practice. Oxford: Blackwell Scientific Publications, 1987. 179 p.

LUKE, D. Tuberculosis in the horse, pig, sheep and goat. The Veterinary Record, v. 70, n. 26, p. 529-536, 1958.

LYNAM, P. A.; BAAB, J. R.; FRAISE, A. P.; Comparison of the mycobactericidal activity of $2 \%$ glutaraldehyde an "Nu-Cidex" ( $0,35 \%$ peracetic acid). Journal of hospital infection.; $v$. 30, p. 237-240, 1995.

MAPA-MINISTÉRIO DA AGRICULTURA, PECUÁRIA E ABASTECIMENTO. Instrução Normativa $n^{\circ} 87$ da secretaria de Defesa Agropecuária, de 10 de dezembro de 2004. Programa Nacional de Sanidade dos Caprinos e Ovinos (PNSCO). Disponível em:

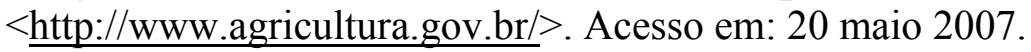

MAPA-MINISTÉRIO DA AGRICULTURA, PECUÁRIA E ABASTECIMENTO. Instrução Normativa SDA $n^{0} 6$ de 8 de janeiro de 2004. Regulamento técnico do Programa Nacional de Controle e Erradicação da Brucelose e Tuberculose, 2004. Disponível em: $<\underline{\text { http://www.agricultura.gov.br/> }}$. Acesso em: 20 maio 2007.

MARCONDES, A. G.; Padronização da técnica de cultivo em camada delgada de agar Middlebrook 7H11 para isolamento de Mycobacterium bovis. 2002. 115f. Tese (Mestrado em Epidemiologia Experimental e Aplicada às Zoonoses)- Faculdade de Medicina Veterinária e Zootecnia Da Universidade de São Paulo, São Paulo, 2002.

MARCONDES. A. G.; SHIKAMA, M. L.; VASCONCELLOS, S. A.; BENITES, N. R., MORAIS, Z. M.; ROXO, E.; DIAS, R. A.; LEÃO, S. L.; PINHEIRO, S. R. Comparação entre a técnica de cultivo em camada delgada de agar Middlebrook 7H11 e meio de Stonebrink para isolamento de Mycobacterium bovis em amostras de campo. Brazilian Journal of veterinary research and animal science, v. 43, n. 3, p. 362-369, 2006.

MCDONNELL, G.; RUSSEL, A. D. Antiseptics and disinfectants: activity, action, and, resistance. Clinical Microbiology Reviews, v. 12, n. 1, p. 147-170, 1999. 
MEJIA, G. I.; CASTRILLON, L.; TRUJILLO, H.; ROBLEDO, J. Á. Microcolony detection in 7H11 thin layer culture is na alternative for rapid diagnosis of Mycobacterium tuberculosis infection. International journal of tuberculosis and lung disease, Colombia, v. 3, n. 2, p. 138-142, 1999.

MILlER, M. A.; PAIGE, J. C. Other food borne infections. Veterinary Clinics of North America: Food Animal Practice, v. 14, n. 1, p. 71-89, 1998.

MINER, N. A.; MCDOWEL, J.W,; WILLCOCKSON, G. W.; BUCKNER, N. I.; STARK, R. L.; WHITMORE, E. J. Antimicrobial and other properties of a new stabilized alkaline glutaraldehyde disinfectant sterilizer. American Journal of hospital Pharmacology, v. 34, n. 4, p. 376-382, 1977.

MOHAN, R. Incidence of tuberculosis in goats. Indian Veterinary Journal, v. 27, p. 153157, 1950.

MORRIS, R. S.; PFEIFFER, D. U.; JACKSON, R. The epidemiology of mycobacterium bovis infections. Veterinary Microbiology, V.40, n. 1/4, p. 153-177, 1994.

MURRAY, C.; MCNUTT, S. H.; PURWIN, P. Tuberculosis of goats. Journal of American Veterinary Medical Association. v. 59, p. 82-84, 1921.

OMIDBAKHSH, N., A new peroxide-based flexible endoscope-compatible high-level disinfectant. American Journal of Infectious control, v. 34, n. 9, p. 571-577, 2006.

ORGANIZACIÓN PANAMERICANA DE LA SALUD. Situación de Ia Tuberculosis bovina en Ias Americas. Washington D. C: 1995 (RIMSA 9 Informativo 26 )

PINHEIRO, S. R. Influência da matéria orgânica na atividade micobactericida de cinco desinfetantes químicos de uso pecuário, 1990. 47 p. Tese (Mestrado). Faculdade de Medicina Veterinária e Zootecnia, Universidade de São Paulo, São Paulo, 1990.

PINHEIRO, S. R.; VASCONCELLOS, S. A.; ITO, F.H.; FERREIRA NETO, J. S.; MORAIS, Z..M. Influência da matéria orgânica na atividade micobactericida de cinco desinfetantes de uso pecuário. Brazilian Journal veterinary Research and Animal Science, São Paulo, v. 29, n. 1, p. 51-60, 1992. 
PINHEIRO, S. R. Influência da origem da estirpe AN5 de Mycobacterium bovis, da temperatura de contato e da matéria orgânica sobre a atividade micobactericida do hipoclorito de sódio ou de aldeídos. 1994. f. 56. Tese (Doutorado em Epidemiologia Experimental e Aplicada às Zoonoses)- Faculdade de Medicina Veterinária e Zootecnia, Universidade de São Paulo, São Paulo, 1994.

PINHEIRO, S. R.; VASCONCELLOS, S. A.; MORAIS, Z. M.; FERREIRA NETO, J. S.; SINHORINI, I. L.; ITO, F. H.; CÔRTES, J. A. Padronização de teste în vitro" para a avaliação da atividade micobactericida do hipoclorito de sódio e de uma combinação de aldeídos. Influência da passagem da estirpe teste ( Mycobacterium bovis - AN5) em hamsters. Arquivos do Instituto Biológico, São Paulo, v. 64, n. 1, p. 11-22, jan./jun., 1997.

PINHEIRO, S. R. Controle da tuberculose bovina versus tratamento O Biológico, São Paulo, v.61, n. 2, p. 139-141 jul/dez., 1999.

PINHEIRO, S. R. Avaliação da atividade micobactericida de desinfetantes químicos sobre estirpes de Mycobacterium avium, isoladas de suínos abatidos no estado de Santa Catarina, no ano de 1999. 2001. f. 14-33. Tese (livre Docência) - Faculdade de Medicina Veterinária e Zootecnia da Universidade de São Paulo, São Paulo, 2001.

POLIAKOV, A. A. Veterinarnaya desinfektsia. 4. ed. Moscú: Kolos, 1975, p. 278.

PRINDLE, R. F. Phenolic compounds. In: BLOCK, S. S., ed. Dísinfection, sterilization and preservation. 3.ed. Philadelphia, Lea \& Febiger, p. 197-224, 1983.

RELYVELD, E. H. Étude du pouvoir bactericide du glutaraidéhyde. Annales de Microbiologie, Paris, v. 128B, n. 4, p. 495-505, 1977.

RUBBO, S. D.; GARDNER, J. F.; WEBB, R. L. Biocidal activities of glutaraldehyde and related compounds. Journal of Applied Bacteriology, v. 30, n. 1, p. 78-87, 1967.

RUBIN, J. Agents for disinfection and control of tuberculosis. In: BLOCK, S. S. (Ed.). Disinfection, sterilization and preservation. 3. ed. Philadelphia: Lea \& Febiger, 1983. p. 414-421.

RUSSELL, A. D. Factors influencing the efficacy of antimicrobial agents. In: RUSSELL, A. D.; HUGO, W. B.; AYLIFFE, G. A. J. (Ed.). Principies and practice of disinfection, preservation and sterilisation. London: Blackweli,1982, p. 107-133. 
RUSSELL, A. D. Activity of biocides against mycobacteria. Journal of Applied Microbiology Symposium supplement, v. 81, p. 87-101, 1996.

SAKO, H.; ISHIDA, N.; MAENO, Y.; SORIMACHI, M. Bactericidal activities of five disinfectants on Aeromonas salmonicida, Vibrio anguillarum an V. Ordalli. Fish Pathology, v. 23, n. 4, p. 219-229, 1988.

SAURAT, M. M. P.; LAUTIÉ, R. De l'action de Quelques desinfectants sur le bacille tuberculeaux. Revue de Médecine Vétérinaire, Toulouse, n. 66, p. 186-199, 1960.

SATTAR, S.A.; ADEGBUNRIN, O.; RAMIREZ, J. Combined use of simulated reuse \& quantitative carrier tests to assess high-level disinfection: experiments with an accelerated hydrogen peroxide-based formulation. Am. J. Infect. Control. V.30, p. 449-457, 2002.

SCHABERG, T.; REICHERT, B.; SCHULIN, T.; LODE, H.; MAUCH, H. Rapid drug susceptibility testing of Mycobacterium tuberculosis using conventional solid media. Berlin, Germany, Europe Respiratory Journal, v. 8, n. 10, p. 1688-1693, Oct. 1995.

SCOTT, E. M.; GORMAN, S. P. Sterilization with glutaraldehyde. In: BLOCK, S. S. (Ed.). Disinfection, sterilization and preservation. 3. ed. Philadelphia: Lea \& Febiger, p. 65-88, 1983..

SEVA, J.; MENCHÉN, V.; NAVARRO, J. A.; PALLARÉS, F. J.; VILLAR, D.; VÁQUEZ, F.; BERNABÉ, A. Caprine tuberculosis eradication program: an immunohistochemical study. Small ruminant research, v. 46, p.107-114, 2002.

SMITH, C. R. Mycobactericidal agents. In: BLOCK, S. S. (Ed.). Disinfection, sterilization and preservation. Philadelphia: Lea \& Febiger, p. 504-513, $1971 .$.

SNYDER, R. W.; CHEATLE, E. Alkaline glutaraldehyde - an effective disinfectant. American Journal of Hospital Pharmacology, n. 22, p. 321-327, 1965.

SOLIMAN, K. N.; ROLLINSON, D. H. L.; BARRON, N. S.; SPRATLING, F. R. An outbreak of naturally acquired tuberculosis in goats. The Veterinary Record, v.65, n. 27, p. 421-425, 1953. 
SOMOSKOVI, A.; MAGYAR, P. Comparison of the mycobacteria growth indicator tube with MB redox, Lowenstein-Jensen, and Middlebrook $7 \mathrm{H} 11$ media for recovery of mycobacteria in clinical specimens. Journal Clinical Microbiology, v. 37, n. 5, p. 1366$1369,1999$.

SPAULDING, E. H.; CUNDY, K. R.; TURNER, F. J. Chemical disinfection of medicai and surgical materiais. In: BLOCK, S. S. (Ed.) Disinfection, sterilization and preservation. 2. ed. Philadelphia: Lea \& Febiger, 1977, p. 654-684.

THOEN, C. O. Tuberculosis. Journal of American Veterinary Medical Association, v. 193, n. 9, p. 1045-1048,1988.

THOREL, M. F. Tubeerculose de la chévre diagnostic biologique. Annales de recherches veterinaires, v.11, n.3, p.251-257, 1980.

TILLEY, F. W. An experimental study of the influence of temperature on the bactericida) actívities of alcohols and phenols. Journal of Bacteriology, n. 43, p521-525, 1942.

TIMENETSKY, J. Avaliação antibacteriana de desinfetantes químicos de uso hospitalar e doméstico.. (Tese Doutoramento) - Instituto de Ciência Biomédicas, Universidade de São Paulo, São Paulo, 1987, 107p.

TIMENETSKY, J. Avaliação microbiológica de desinfetantes químicos de uso doméstico. Revista de Saúde Pública da Faculdade de Saúde Pública da Universidade de São Paulo, v. 24, n. 1, p. 47-50, 1990.

UNIVERSIDAD DE LAS NACIONES UNIDAS. Nuevas tecnologias para el diagnostico y pruebas de susceptibilidad a drogas de $M$. tuberculosis para paises en vias de desarollo. In: Programa de biotecnologia para Latinoamérica y el Caribe - BIOLAC; Red Latinoamericana y del Caribe de tuberculosis - RELACTB, La Paz, Bolivia. Curso...p. 18-21.

VERA, A.; VOLKOVSKY, G.; SANCHEZ, I.; COTRINA, N. Acción desinfectantes contra M: bovis: hidróxido de sódio,mezcla de este producto con formaldehido, productos clorados y acido peracético. Cienc.Tec.Agric.Vet., v. 7, p. 29-38, 1985. 
VIZCAINO-ALCAIDE ${ }^{1}$, M. J.; HERRUZO-CABRERA, R.; FERNANDEZ-ACENERO M.

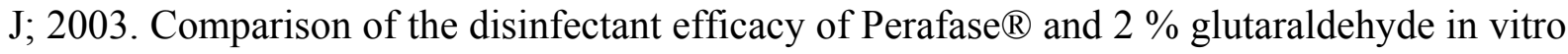
tests. Journal of hospital infection, v. 53, p. 124-128.

WAISBICH, E. Resistência do bacilo de koch aos agentes físicos, químicos e quimioterápicos. Laes, v. 8, p. 12-13, dez/jan, 1986-1987.

WANG, G. Q.; ZHANG, C. W.; LIU, H. C.; CHEN, Z. B. Comparison of susceptibilities of M. tuberculosis H37Ra and M. chelonei subsp. Abcessus to disinfectants. Biomedical and environmental sciences., v.18, p. 124-127, 2005.

WELCH, D. F.; GURUSWAMY, A. P.; SIDES, S. J.; SHAW, C. H.; GILCHRIST, M. J. Timely culture for mycobacteria which utilizes a microcolony method. Journal Clin. Microbiology, v. 31, n. 8, p. 2178-2184, 1993.

WHITMORE, E. J.; MINER, N. A. Analysis and optimization of a quantitative organic soil neutralization test for desinfectants. Journal of the AOAC., v. 59, n. 6, p. 1344-1351, 1976.

WIEST, J. M. Untersuchungen über den einfluss der Temperatur auf die Bakterizide wirkung chemischer Desinfektionsmittel. 1978. 77 f. Inaugural Dissertation (Doktorgrades) - Fachbereich Veterinãrmedizin und Tierzucht der Justus-Liebig-Universitãt zu Giessen, Giessen, 1978.

WILLIAMS, R. S.; HOY, W. A. The viability of B. tuberculosis (bovinus) on pasture land, in stored feaces and in liquid manure. J. Hyg., n. 30, p.413-419, 1930.

WORLD HEALTH ORGANIZATION. Guidelines on disínfectíon in animal husbandry for prevention and control of zoonotic diseases. Geneva: 1984. 49 p. (WHO/VPH/84.4).

ZANON, U. Desinfetantes, antissépticos e infecção hospitalar. O Semestre terapêutico, Rio de Janeiro, n. 28, p. 48-64, 1973.

ZIEGLER, V. L.; GRATSCH, D. Importance of animal passages to activation of bacterial test strains for disinfectant testing. Mh.Vet.-Med., n. 42, p. 68, 1987.

\footnotetext{
${ }^{1}$ BRITISH SOCIETY OF GASTROENTEROLOGY ENDOSCOPY COMITMITEE. Aldehyde disinfectants and health in endoscopy units. Gut, v.34, p. 1641-1645, 1993.
} 
ANEXO A - Método de preparo do meio de Stonebrink

\section{Base de sais}

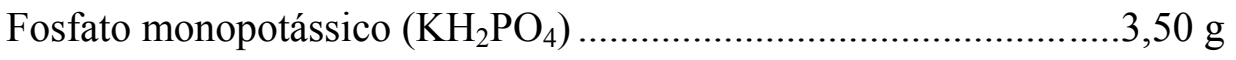

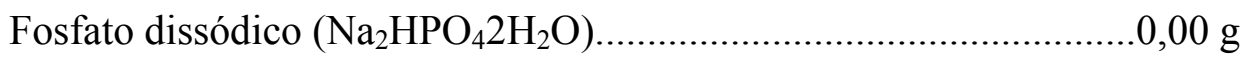

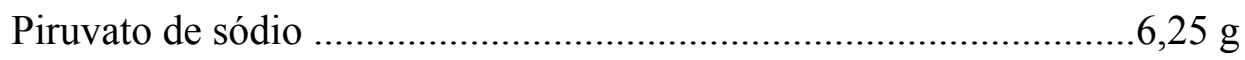

Água destilada q.s.p. -............................................................500,00 mL

OBS: caso se utilize fosfato dissódico com 12 moléculas de $\mathrm{H}_{2} \mathrm{O}$, utilizar 4,0 g. se for o fosfato' dissódico anidro, utilizar $1,59 \mathrm{~g}$.

Conteúdo de $\approx 20$ ovos (suspensão) $1000,00 \mathrm{~mL}$

Solução aquosa de verde de malaquita a $2 \%$. $.20,00 \mathrm{~mL}$

Dissolver os sais na água destilada e autoclavar a $121^{\circ} \mathrm{C}$ por 15 minutos. Aguardar esfriar a base e acrescentar os ovos e o verde de malaquita. Homogeneizar em agitador magnético por uma hora. Filtrar em gaze estéril (dobrada em 4) e distribuir nos tubos. Coagular ${ }^{1}$ a $80^{\circ} \mathrm{C}$ por 30 minutos. 
ANEXO B - Método de preparo do Meio de Middlebrook 7H11 modificado

Middlebrook 7H11 ágar..........................................................18,00g

Hidrolizado de caseína (digestão pancreática de caseína) ....................1,00 g

Glicerol (glicerina)...........................................................5,00 mL

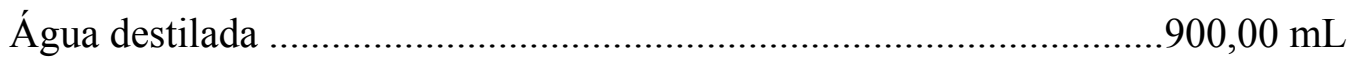

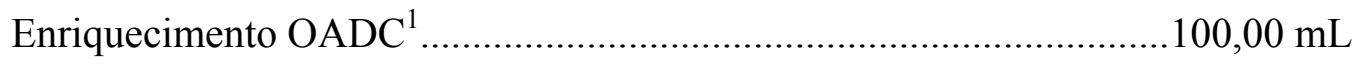

Misturar no Erlenmeyer o ágar, a caseína e o glicerol. Acrescentar a água destilada pelas paredes para evitar a formação de espuma. Depois de tudo misturado, agitar lentamente para que o glicerol se misture com a solução. Autoclavar a $121^{\circ} \mathrm{C}$ por 15 minutos. Aguardar o resfriamento a $56^{\circ} \mathrm{C}$ e adicionar assepticamente o enriquecimento OADC. O enriquecimento deve ser retirado da geladeira antes, para que esteja na temperatura ambiente na hora de ser adicionado ao meio. Homogeneizar novamente cuidando para evitar a formação de bolhas. Distribuir em placas e após a solidificação proceder aos testes de esterilidade por no mínimo 48 horas.

$\mathrm{Na}$ hora de distribuir, deixar a ponta da pipeta no canto da placa e descer o meio devagar para evitar a formação de bolhas. Não deixar descer todo o meio da pipeta; deixar um pouco de meio no funil da pipeta para que não fiquem bolhas.

1 BBLtn Middlebrook OADC Enrictunent - I3ecton Dickson Microbiology, Systems - Sparks, MD 21152 
ANEXO C - Preparo do ambiente de microaerofilia para incubação das placas com meio Middlebrook 7H11 modificado

\section{Preparo da solução de sulfato de cobre}

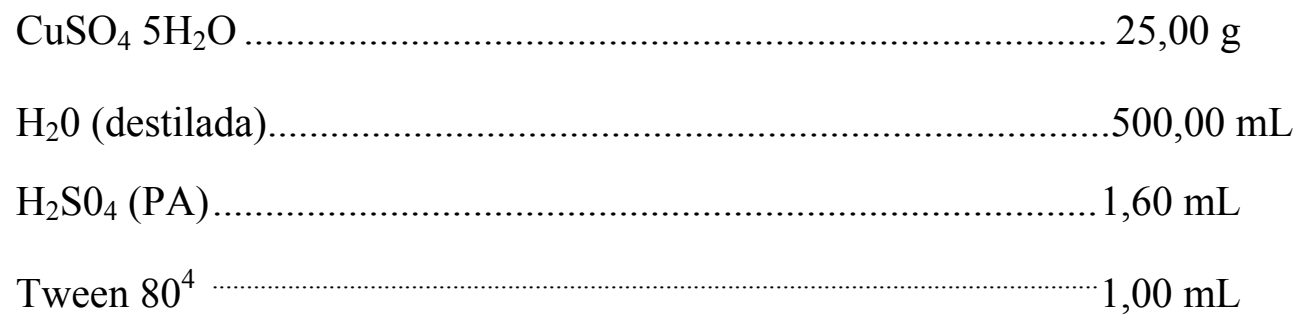

Depois de secas e vedadas, as placas são colocadas nas caixas tipo "tuperware" com a tampa para baixo. Em um dos cantos da caixa é colocada uma placa de Petri vazia (aberta) contendo um chumaço de palha de aço comum

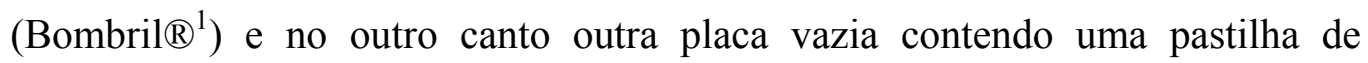
antiácido efervescente Alka Seltzer. Em seguida, a palha de aço é molhada com $5 \mathrm{ml}$ da solução de sulfato de cobre. A caixa então deve ser lacrada rapidamente com a película plástica ${ }^{2}$ para evitar a entrada de ar. 
Apêndice A - Médias das contagens das U.F.C. de M.bovis em placas com 7H11, segundo o princípio ativo do desinfetante químico, a temperatura de contacto, presença ou ausência de matéria orgânica. São Paulo - 2007.

\begin{tabular}{|c|c|c|c|c|c|c|c|c|c|c|c|c|c|c|c|c|c|c|c|c|c|c|c|c|}
\hline \multirow[t]{3}{*}{$\mathrm{R} / \mathrm{L} / \mathrm{D}$} & \multicolumn{4}{|c|}{ Controle } & \multicolumn{4}{|c|}{ Hipoclorito de sódio } & \multicolumn{4}{|c|}{ Glutaraldeído } & \multicolumn{4}{|c|}{ Ácido peracético } & \multicolumn{4}{|c|}{ Iodóforo } & \multicolumn{4}{|c|}{ Fenol } \\
\hline & \multicolumn{2}{|c|}{$4^{\circ} \mathrm{C}$} & \multicolumn{2}{|c|}{ TA } & \multicolumn{2}{|c|}{$4^{\circ} \mathrm{C}$} & \multicolumn{2}{|c|}{ TA } & \multicolumn{2}{|c|}{$4^{\circ} \mathrm{C}$} & \multicolumn{2}{|c|}{ TA } & \multicolumn{2}{|c|}{$4^{\circ} \mathrm{C}$} & \multicolumn{2}{|c|}{ TA } & \multicolumn{2}{|c|}{$4^{\circ} \mathrm{C}$} & \multicolumn{2}{|c|}{ TA } & \multicolumn{2}{|c|}{$4^{\circ} \mathrm{C}$} & \multicolumn{2}{|c|}{ TA } \\
\hline & smo & $\mathrm{cmo}$ & smo & $\mathrm{Cmo}$ & smo & $\mathrm{cmo}$ & smo & $\mathrm{cmo}$ & smo & $\mathrm{cmo}$ & smo & $\mathrm{cmo}$ & smo & $\mathrm{cmo}$ & smo & $\mathrm{cmo}$ & smo & $\mathrm{cmo}$ & smo & $\mathrm{cmo}$ & smo & $\mathrm{cmo}$ & smo & $\mathrm{cmo}$ \\
\hline 1.1 .1 & 60 & 119,6 & 51,6 & 81,9 & 0 & 0 & 0 & 0 & 0 & 0 & 0 & 0 & 0 & 0 & 0 & 0 & 0 & 8,5 & 0 & 0 & 0 & 0,6 & 0 & 0 \\
\hline 1.2 .1 & 70,8 & 124,4 & 57,1 & 103,7 & 0 & 0 & 0 & 0 & 0 & 0 & 0 & 0 & 0 & 0 & 0 & 0 & 0 & 10,9 & 0 & 0 & 0 & 1,9 & 0 & 0 \\
\hline 1.1 .2 & 29,1 & 81,3 & 44,3 & 74,2 & 0 & 0 & 0 & 0 & 0 & 0 & 0 & 0 & 0 & 0 & 0 & 0 & 0 & 4,4 & 0 & 0 & 0 & 1,3 & 0 & 0 \\
\hline 1.2 .2 & 34,1 & 97 & 52,7 & 95,8 & 0 & 0 & 0 & 0 & 0 & 0 & 0 & 0 & 0 & 0 & 0 & 0 & 0 & 9,1 & 0 & 0 & 0 & 1,7 & 0 & 0 \\
\hline 2.1 .1 & 78,5 & 126,7 & 78,9 & 103 & 0 & 0 & 0 & 0 & 0 & 0 & 0 & 0 & 0 & 0 & 0 & 0 & 0 & 111,4 & 0 & 117,5 & 0 & 61,6 & 0 & 0 \\
\hline 2.2 .1 & 129 & 196,5 & 112,5 & 160,1 & 0 & 0 & 0 & 0 & 0 & 0 & 0 & 0 & 0 & 0 & 0 & 0 & 0 & 196 & 0 & 177,5 & 0 & 89 & 0 & 0 \\
\hline 2.1 .2 & 129 & 168,4 & 116 & 78,9 & 0 & 0 & 0 & 0 & 0 & 0 & 0 & 0 & 0 & 0 & 0 & 0 & 0 & 86,3 & 0 & 130 & 0 & 55,3 & 0 & 0 \\
\hline 2.2 .2 & 190,5 & 238,6 & 169,3 & 119,3 & 0 & 0 & 0 & 0 & 0 & 0 & 0 & 0 & 0 & 0 & 0 & 0 & 0 & 147,3 & 0 & 199,5 & 0 & 90 & 0 & 0 \\
\hline 3.1 .1 & 90,9 & 78,9 & $\mathrm{C}$ & 30,1 & 0 & 0 & 0 & 0 & 0,1 & 3,5 & 0 & 0 & 0 & 0 & 0 & 0 & 0 & 73,6 & 0 & 90,9 & 0 & 2 & 0 & 0 \\
\hline 3.2 .1 & 116,2 & 107,5 & $\mathrm{C}$ & 118,3 & 0 & 0 & 0 & 0 & 1,2 & 12,7 & 0 & 0 & 0 & 0 & 0 & 0 & 0 & 90,4 & 0 & 121,1 & 0 & 5,8 & 0 & 0 \\
\hline 3.1 .2 & 83,3 & 64,5 & 113,4 & 59,3 & 0 & 0 & 0 & 0 & 0,5 & 1,7 & 0 & 0 & 0 & 0 & 0 & 0 & 0 & 72,2 & 0 & 93,9 & 0 & 2,1 & 0 & 0 \\
\hline 3.2 .2 & 105,8 & 84,4 & 130,2 & 82,6 & 0 & 0 & 0 & 0 & 2,3 & 7,7 & 0 & 0 & 0 & 0 & 0 & 0 & 0 & 94,5 & 0 & 121,1 & 0 & 8,2 & 0 & 0 \\
\hline 4.1 .1 & 110,8 & 97,8 & 81 & 106,8 & 0 & 0,4 & 0 & 0 & 10,3 & 0,1 & 0 & 3,5 & 0 & 0 & 0 & 0 & 0 & 87,5 & 0 & 50,9 & 0 & 0,9 & 0 & 0 \\
\hline 4.2 .1 & 174,2 & 116,5 & 122,6 & 155,8 & 0 & 1,1 & 0 & 0 & 27,1 & 2,1 & 0 & 12,4 & 0 & 0 & 0 & 0 & 0 & 128 & 0 & 84,2 & 0 & 5,1 & 0 & 0 \\
\hline 4.1 .2 & 71,4 & 52,5 & 70 & 57,9 & 0 & 0,2 & 0 & 0 & 5,4 & 0,2 & 0 & $\mathrm{C}$ & 0 & 0 & 0 & 0 & 0 & 79,7 & 0 & 48,2 & 0 & 0,7 & 0 & 0 \\
\hline 4.2 .2 & 106,2 & 68,2 & 91,4 & 90,4 & 0 & 1,5 & 0 & 0 & 26,4 & 1,7 & 0 & $\mathrm{C}$ & 0 & 0 & 0 & 0 & 0 & 118 & 0 & 76,4 & 0 & 7,6 & 0 & 0 \\
\hline 5.1 .1 & 38,8 & 13,8 & 17,8 & 13,6 & 0 & 0 & 0 & 0 & 3,9 & 0,9 & 0 & 0 & 0 & 0 & 0 & 0 & 0 & 16,6 & 0 & 13,4 & 0 & 0,6 & 0 & 0 \\
\hline 5.2 .1 & 70,2 & 35,5 & 40,9 & 29,8 & 0 & 0 & 0 & 0 & 10 & 4,5 & 0 & 0 & 0 & 0 & 0 & 0 & 0 & 43,5 & 0 & 33,9 & 0 & 2,1 & 0 & 0 \\
\hline 5.1 .2 & 35,2 & 21,6 & 20,4 & 17,8 & 0 & 0 & 0 & 0 & 2,2 & 0,5 & 0 & 0 & 0 & 0 & 0 & 0 & 0 & 19,6 & 0 & 11,8 & 0 & 0,8 & 0 & 0 \\
\hline 5.2 .2 & 65,2 & 45,4 & 48,9 & 40,9 & 0 & 0 & 0 & 0 & 7,9 & 4,3 & 0 & 0 & 0 & 0 & 0 & 0 & 0 & 50,4 & 0 & 31,6 & 0 & 2,1 & 0 & 0 \\
\hline 6.1 .1 & 117 & 102,6 & 257 & 74,3 & 0 & 1,7 & 0 & 0 & 0,4 & 0 & 0 & 0 & 0 & 0 & 0 & 0 & 0 & 39 & 12,8 & 30,2 & 0 & 0 & 0 & 0 \\
\hline 6.2 .1 & 188,5 & 181 & 302,5 & 108,5 & 0 & 4 & 0 & 0 & 3,7 & 0,2 & 0 & 0 & 0 & 0 & 0 & 0 & 0 & 67,1 & 27,5 & 51,6 & 0 & 0 & 0 & 0 \\
\hline 6.1 .2 & 116,7 & 115 & 262,5 & $\mathrm{C}$ & 0 & 0,3 & 0 & 0 & 0,7 & 0 & 0 & 0 & 0 & 0 & 0 & 0 & 0 & 78,1 & 7,1 & 51,5 & 0 & 0 & 0 & 0 \\
\hline 6.2 .2 & 197,5 & 164,5 & 310 & $\mathrm{C}$ & 0 & 4 & 0 & 0 & 5,1 & 0 & 0 & 0 & 0 & 0 & 0 & 0 & 0 & 124,4 & 16,2 & 107 & 0 & 0,1 & 0 & 0 \\
\hline 7.1 .1 & 124 & 97,6 & 92 & 77,5 & 0 & 0 & 0 & 0 & 0,1 & 7,8 & 0 & 0 & 0 & 0 & 0 & 0 & 0 & 137,7 & 0 & 140,4 & 0 & 20,4 & 0 & 1,1 \\
\hline 7.2.1 & 174 & 100,7 & 145 & 89,2 & 0 & 0 & 0 & 0 & 0,1 & 24,2 & 0 & 0 & 0 & 0 & 0 & 0 & 0 & 144,5 & 0 & 152,2 & 0 & 35,8 & 0 & 3,7 \\
\hline 7.1 .2 & 151,5 & 142,7 & 139,3 & 57,4 & 0 & 0 & 0 & 0 & 0,4 & 11,2 & 0 & 0 & 0 & 0 & 0 & 0 & 0 & 126,8 & 0 & 109 & 0 & 9,4 & 0 & 4,2 \\
\hline 7.2 .2 & 198,2 & 146,5 & 159,8 & 73,4 & 0 & 0 & 0 & 0 & 0,8 & 31,9 & 0 & 0 & 0 & 0 & 0 & 0 & 0 & 139,8 & 0 & 132,5 & 0 & 15,4 & 0 & 6,3 \\
\hline 8.1 .1 & 128,7 & 110,3 & 118,6 & 104,7 & 0 & 0 & 0 & 0 & 15,4 & 52,9 & 0 & 0 & 0 & 0 & 0 & 0 & 0 & 114,5 & 0 & 128 & 0 & 3,8 & 0 & 0 \\
\hline 8.2 .1 & 145 & $\mathrm{C}$ & 146 & 126 & 0 & 0 & 0 & 0 & 50,9 & 109,6 & 0 & 0 & 0 & 0 & 0 & 0 & 0 & 144 & 0 & 156 & 0 & 15,1 & 0 & 0 \\
\hline 8.1 .2 & 112,9 & 95,3 & 177,8 & 138 & 0 & 0 & 0 & 0 & 9,1 & 34,7 & 0 & 0 & 0 & 0 & 0 & 0 & 0 & 117,5 & 0 & 129,5 & 0 & 4,2 & 0 & 0 \\
\hline
\end{tabular}




\begin{tabular}{|c|c|c|c|c|c|c|c|c|c|c|c|c|c|c|c|c|c|c|c|c|c|c|c|c|}
\hline \multirow[t]{3}{*}{$\mathrm{R} / \mathrm{L} / \mathrm{D}$} & \multicolumn{4}{|c|}{ Controle } & \multicolumn{4}{|c|}{ Hipoclorito de sódio } & \multicolumn{4}{|c|}{ Glutaraldeído } & \multicolumn{4}{|c|}{ Ácido peracético } & \multicolumn{4}{|c|}{ Iodóforo } & \multicolumn{4}{|c|}{ Fenol } \\
\hline & \multicolumn{2}{|c|}{$4^{\circ} \mathrm{C}$} & \multicolumn{2}{|c|}{ TA } & \multicolumn{2}{|c|}{$4^{\circ} \mathrm{C}$} & \multicolumn{2}{|c|}{ TA } & \multicolumn{2}{|c|}{$4^{\circ} \mathrm{C}$} & \multicolumn{2}{|c|}{ TA } & \multicolumn{2}{|c|}{$4^{\circ} \mathrm{C}$} & \multicolumn{2}{|c|}{ TA } & \multicolumn{2}{|c|}{$4^{\circ} \mathrm{C}$} & \multicolumn{2}{|c|}{ TA } & \multicolumn{2}{|c|}{$4^{\circ} \mathrm{C}$} & \multicolumn{2}{|c|}{ TA } \\
\hline & smo & $\mathrm{cmo}$ & smo & $\mathrm{Cmo}$ & smo & $\mathrm{cmo}$ & smo & $\mathrm{cmo}$ & smo & $\mathrm{cmo}$ & smo & $\mathrm{cmo}$ & smo & $\mathrm{cmo}$ & smo & $\mathrm{cmo}$ & smo & $\mathrm{cmo}$ & smo & $\mathrm{cmo}$ & smo & $\mathrm{cmo}$ & smo & $\mathrm{cmo}$ \\
\hline 8.2 .2 & 131,5 & 119,8 & 176,5 & 152,9 & 0 & 0 & 0 & 0 & 45,9 & 63,8 & 0 & 0 & 0 & 0 & 0 & 0 & 0 & 144,5 & 0 & 151,8 & 0 & 17,8 & 0 & 0 \\
\hline 9.1 .1 & 165 & 276 & 166,5 & 177,5 & 0 & 30,9 & 0 & 0 & 139,3 & 25,9 & 0 & 0 & 0 & 0 & 0 & 0 & 0 & 162 & 0 & 181,5 & 0 & 47,5 & 0 & 0 \\
\hline 9.2 .1 & 204 & 301 & 177,5 & 210,5 & 0 & 64,2 & 0 & 0 & 192,8 & 59 & 0,2 & 0 & 0 & 0 & 0 & 0 & 0 & 190,5 & 0 & 147,3 & 0 & 80,4 & 0 & 0,1 \\
\hline 9.1 .2 & 170 & 222 & 216 & 191,5 & 0 & 22,2 & 0 & 0 & 144,5 & 38,3 & 0 & 0 & 0 & 0 & 0 & 0 & 0 & 195 & 0 & 131,5 & 0 & 74,9 & 0 & 0 \\
\hline 9.2 .2 & 186 & 279,5 & 231 & 222,5 & 0 & 41,4 & 0 & 0 & 181,5 & 77,8 & 0 & 0 & 0 & 0 & 0 & 0 & 0 & 206 & 0 & 221 & 0 & 120 & 0 & 0,1 \\
\hline 10.1 .1 & 276 & 213,5 & 167 & 183,5 & 0 & 17,4 & 0 & 0 & 81,4 & 102,8 & 0,2 & 1,7 & 0 & 0 & 0 & 0 & 0 & 132 & 0 & 179 & 0 & 12,2 & 0 & 0 \\
\hline 10.2 .1 & 277,5 & 217,5 & 188,5 & 193,5 & 0 & 22,8 & 0 & 0 & 100 & 113,7 & 0,8 & 3 & 0 & 0 & 0 & 0 & 0 & 145 & 0 & 182,8 & 0 & 15,9 & 0 & 0 \\
\hline 10.1 .2 & 255 & 173 & 171,5 & 199 & 0 & 16,5 & 0 & 0 & 70 & 85,4 & 0,6 & 0,6 & 0 & 0 & 0 & 0 & 0 & 115,5 & 0 & 176 & 0 & 15,9 & 0 & 0 \\
\hline 10.2 .2 & 269 & 175 & 182,5 & 202 & 0 & 20,2 & 0 & 0 & 90,7 & 101,5 & 1,2 & 1,4 & 0 & 0 & 0 & 0 & 0 & 132,5 & 0 & 187,5 & 0 & 20,6 & 0 & 0 \\
\hline
\end{tabular}

R Repetições

L Leituras $\left(1^{\circ}\right.$ e $2^{\circ}$ dias $)$

D Duplicatas

$4^{\circ} \mathrm{C} \quad$ Temperatura de 4 Graus Celsius
Ta Temperatura ambiente $\left(20^{\circ}\right.$ a $\left.22^{\circ} \mathrm{C}\right)$

SMO Ausência de matéria orgânica

CMO Presença de matéria orgânica 
Apêndice B - Escores de crescimento de M.bovis na superfície do meio de Stonebrik em tubos, segundo o princípio ativo do desinfetante químico, a temperatura de contacto e presença ou ausência de matéria orgânica. São Paulo - 2007.

\begin{tabular}{|c|c|c|c|c|c|c|c|c|c|c|c|c|c|c|c|c|c|c|c|c|c|c|c|c|}
\hline \multirow{3}{*}{$\mathrm{R} / \mathrm{L} / \mathrm{D}$} & \multicolumn{4}{|c|}{ Controle } & \multicolumn{4}{|c|}{ Hipoclorito de sódio } & \multicolumn{4}{|c|}{ Glutaraldeído } & \multicolumn{4}{|c|}{ Ácido peracético } & \multicolumn{4}{|c|}{ Iodóforo } & \multicolumn{4}{|c|}{ Fenol } \\
\hline & \multicolumn{2}{|c|}{$4^{\circ}$} & \multicolumn{2}{|c|}{ TA } & \multicolumn{2}{|c|}{$4^{\mathrm{o}}$} & \multicolumn{2}{|c|}{ TA } & \multicolumn{2}{|c|}{$4^{\circ}$} & \multicolumn{2}{|c|}{ TA } & \multicolumn{2}{|c|}{$4^{\circ}$} & \multicolumn{2}{|c|}{$\mathrm{TA}$} & \multicolumn{2}{|c|}{$4^{\circ}$} & \multicolumn{2}{|c|}{ TA } & \multicolumn{2}{|c|}{$4^{\circ}$} & \multicolumn{2}{|c|}{ TA } \\
\hline & Smo & $\mathrm{cmo}$ & smo & $\mathrm{Cmo}$ & smo & $\mathrm{cmo}$ & smo & $\mathrm{cmo}$ & smo & $\mathrm{cmo}$ & smo & $\mathrm{cmo}$ & smo & $\mathrm{cmo}$ & smo & $\mathrm{cmo}$ & smo & $\mathrm{cmo}$ & smo & $\mathrm{cmo}$ & smo & $\mathrm{cmo}$ & smo & $\mathrm{cmo}$ \\
\hline 1.1 .1 & 5 & 1 & 1 & 1 & 0 & 0 & 0 & 0 & 4 & 1 & 0 & 0 & 0 & 0 & 0 & 0 & 0 & 4 & 0 & 0 & 0 & 0 & 0 & 0 \\
\hline 1.2 .1 & 5 & 2 & 2 & 1 & 0 & 0 & 0 & 0 & 3 & 1 & 0 & 0 & 0 & 0 & 0 & 0 & 0 & 4 & 0 & 1 & 0 & 1 & 0 & 0 \\
\hline 1.1 .2 & 3 & 1 & 3 & 5 & 0 & 0 & 0 & 0 & 1 & 0 & 0 & 0 & 0 & 0 & 0 & 0 & 0 & 3 & 0 & 0 & 0 & 2 & 0 & 0 \\
\hline 1.2 .2 & 5 & 2 & 5 & 5 & 0 & 0 & 0 & 0 & 3 & 0 & 0 & 0 & 0 & 0 & 0 & 0 & 0 & 4 & 0 & 0 & 0 & 3 & 0 & 0 \\
\hline 2.1 .1 & 5 & 2 & 2 & 4 & 0 & 0 & 0 & 0 & 0 & 0 & 0 & 0 & 0 & 0 & 0 & 0 & 0 & 3 & 0 & 4 & 0 & 1 & 0 & 0 \\
\hline 2.2 .1 & 5 & 3 & 3 & 4 & 0 & 0 & 0 & 0 & 1 & 0 & 0 & 0 & 0 & 0 & 0 & 0 & 0 & 4 & 0 & 5 & 0 & 2 & 0 & 0 \\
\hline 2.1 .2 & 3 & 3 & 2 & 4 & 0 & 0 & 0 & 0 & 0 & 0 & 0 & 0 & 0 & 0 & 0 & 0 & 0 & 4 & 0 & 4 & 0 & 2 & 0 & 0 \\
\hline 2.2 .2 & 3 & 3 & 2 & 5 & 0 & 0 & 0 & 0 & 1 & 0 & 0 & 0 & 0 & 0 & 0 & 0 & 1 & 5 & 0 & 5 & 0 & 3 & 0 & 0 \\
\hline 3.1 .1 & 1 & 2 & 1 & 4 & 0 & 0 & 0 & 0 & 0 & 1 & 0 & 0 & 0 & 0 & 0 & 0 & 0 & 3 & 0 & 4 & 0 & 0 & 0 & 0 \\
\hline 3.2 .1 & 4 & 3 & 3 & 4 & 0 & 0 & 0 & 0 & 1 & 2 & 0 & 0 & 0 & 0 & 0 & 0 & 0 & 2 & 0 & 3 & 0 & 2 & 0 & 0 \\
\hline 3.1 .2 & 2 & 2 & 3 & 4 & 0 & 0 & 0 & 0 & 0 & 2 & 0 & 0 & 0 & 0 & 0 & 0 & 0 & 5 & 0 & 2 & 0 & 0 & 0 & 0 \\
\hline 3.2 .2 & 3 & 3 & 4 & 4 & 0 & 0 & 0 & 0 & 1 & 2 & 0 & 0 & 0 & 0 & 0 & 0 & 0 & 5 & 1 & 3 & 0 & 2 & 0 & 0 \\
\hline 4.1 .1 & 3 & 2 & 3 & 3 & 0 & 0 & 0 & 0 & 3 & 0 & 0 & 0 & 0 & 0 & 0 & 0 & 0 & 4 & 0 & 4 & 0 & 1 & 0 & 0 \\
\hline 4.2 .1 & 4 & 4 & 3 & 3 & 0 & 1 & 0 & 0 & 5 & 1 & 0 & 0 & 0 & 0 & 0 & 0 & 0 & 5 & 0 & 5 & 0 & 2 & 0 & 0 \\
\hline 4.1 .2 & 2 & 2 & 3 & 3 & 0 & 1 & 0 & 0 & 3 & 0 & 0 & 0 & 0 & 0 & 0 & 0 & 0 & 4 & 0 & 1 & 0 & 1 & 0 & 0 \\
\hline 4.2 .2 & 4 & 3 & 4 & 4 & 0 & 1 & 0 & 0 & 4 & 1 & 0 & 0 & 0 & 0 & 0 & 0 & 0 & 5 & 0 & 2 & 0 & 2 & 0 & 0 \\
\hline 5.1 .1 & 2 & 2 & 3 & 4 & 0 & 0 & 0 & 0 & 1 & 1 & 0 & 0 & 0 & 0 & 0 & 0 & 0 & 2 & 0 & 3 & 0 & 1 & 0 & 0 \\
\hline 5.2 .1 & 4 & 4 & 4 & 5 & 0 & 0 & 0 & 0 & 2 & 1 & 0 & 0 & 0 & 0 & 0 & 0 & 0 & 3 & 0 & 3 & 0 & 2 & 0 & 0 \\
\hline 5.1 .2 & 3 & 5 & 3 & 1 & 0 & 0 & 0 & 0 & 2 & 1 & 0 & 0 & 0 & 0 & 0 & 0 & 0 & 3 & 0 & 1 & 0 & 1 & 0 & 0 \\
\hline 5.2 .2 & 3 & 5 & 4 & 3 & 0 & 0 & 0 & 0 & 3 & 1 & 0 & 0 & 0 & 0 & 0 & 0 & 0 & 5 & 0 & 2 & 0 & 2 & 0 & 0 \\
\hline 6.1 .1 & 4 & 5 & 5 & 3 & 0 & 1 & 0 & 0 & 1 & 1 & 0 & 0 & 0 & 0 & 0 & 0 & 0 & 3 & 1 & 3 & 0 & 0 & 0 & 0 \\
\hline 6.2 .1 & 5 & 5 & 5 & 5 & 0 & 2 & 0 & 0 & 2 & 3 & 0 & 0 & 0 & 0 & 0 & 0 & 1 & 4 & 2 & 4 & 0 & 1 & 0 & 0 \\
\hline 6.1 .2 & 4 & 5 & 5 & 2 & 0 & 0 & 0 & 0 & 1 & 0 & 0 & 0 & 0 & 0 & 0 & 0 & 0 & 3 & 1 & 2 & 0 & 0 & 0 & 0 \\
\hline 6.2 .2 & 5 & 5 & 5 & 4 & 0 & 2 & 0 & 1 & 2 & 1 & 0 & 0 & 0 & 0 & 0 & 0 & 0 & 4 & 3 & 4 & 0 & 1 & 0 & 0 \\
\hline 7.1 .1 & 3 & 3 & 5 & 3 & 0 & 0 & 0 & 0 & 0 & 1 & 0 & 0 & 0 & 0 & 0 & 0 & 0 & 2 & 0 & 3 & 0 & 1 & 0 & 0 \\
\hline 7.2 .1 & 3 & 3 & 5 & 3 & 0 & 0 & 0 & 0 & 0 & 2 & 0 & 0 & 0 & 0 & 0 & 0 & 0 & 4 & 0 & 4 & 0 & 2 & 0 & 0 \\
\hline
\end{tabular}




\begin{tabular}{|c|c|c|c|c|c|c|c|c|c|c|c|c|c|c|c|c|c|c|c|c|c|c|c|c|}
\hline \multirow{3}{*}{$\mathrm{R} / \mathrm{L} / \mathrm{D}$} & \multicolumn{4}{|c|}{ Controle } & \multicolumn{4}{|c|}{ Hipoclorito de sódio } & \multicolumn{4}{|c|}{ Glutaraldeído } & \multicolumn{4}{|c|}{ Ácido peracético } & \multicolumn{4}{|c|}{ Iodóforo } & \multicolumn{4}{|c|}{ Fenol } \\
\hline & \multicolumn{2}{|c|}{$4^{\circ}$} & \multicolumn{2}{|c|}{ TA } & \multicolumn{2}{|c|}{$4^{\circ}$} & \multicolumn{2}{|c|}{ TA } & \multicolumn{2}{|c|}{$4^{\circ}$} & \multicolumn{2}{|c|}{ TA } & \multicolumn{2}{|c|}{$4^{\circ}$} & \multicolumn{2}{|c|}{ TA } & \multicolumn{2}{|c|}{$4^{\circ}$} & \multicolumn{2}{|c|}{ TA } & \multicolumn{2}{|c|}{$4^{\circ}$} & \multicolumn{2}{|c|}{ TA } \\
\hline & Smo & $\mathrm{cmo}$ & smo & $\mathrm{Cmo}$ & smo & $\mathrm{cmo}$ & smo & $\mathrm{cmo}$ & smo & $\mathrm{cmo}$ & smo & $\mathrm{cmo}$ & smo & $\mathrm{cmo}$ & smo & $\mathrm{cmo}$ & smo & $\mathrm{cmo}$ & smo & $\mathrm{cmo}$ & smo & $\mathrm{cmo}$ & smo & $\mathrm{cmo}$ \\
\hline 7.1 .2 & 3 & 3 & 5 & 3 & 0 & 0 & 0 & 0 & 0 & 1 & 0 & 0 & 0 & 0 & 0 & 0 & 0 & 2 & 0 & 3 & 0 & 1 & 0 & 0 \\
\hline 7.2 .2 & 3 & 3 & 5 & 3 & 0 & 0 & 0 & 0 & 0 & 2 & 0 & 0 & 0 & 0 & 0 & 0 & 0 & 4 & 0 & 4 & 0 & 2 & 0 & 0 \\
\hline 8.1 .1 & 4 & 5 & 5 & 4 & 0 & 0 & 0 & 0 & 2 & 4 & 0 & 0 & 0 & 0 & 0 & 0 & 0 & 3 & 0 & 5 & 0 & 1 & 0 & 0 \\
\hline 8.2 .1 & 4 & 5 & 5 & 4 & 0 & 1 & 0 & 0 & 4 & 4 & 0 & 0 & 0 & 0 & 0 & 0 & 0 & 3 & 0 & 5 & 0 & 2 & 0 & 0 \\
\hline 8.1 .2 & 4 & 3 & 5 & 4 & 0 & 0 & 0 & 0 & 3 & 4 & 0 & 0 & 0 & 0 & 0 & 0 & 0 & 5 & 0 & 5 & 0 & 1 & 0 & 0 \\
\hline 8.2 .2 & 4 & 4 & 5 & 4 & 0 & 0 & 0 & 0 & 4 & 4 & 0 & 0 & 0 & 0 & 0 & 0 & 0 & 5 & 0 & 5 & 0 & 2 & 0 & 0 \\
\hline 9.1 .1 & 4 & 4 & 4 & 4 & 0 & 3 & 0 & 0 & 5 & 4 & 2 & 2 & 0 & 0 & 0 & 0 & 0 & 5 & 0 & 5 & 0 & 4 & 0 & 1 \\
\hline 9.2 .1 & 4 & 4 & 4 & 4 & 0 & 3 & 0 & 0 & 5 & 4 & 2 & 2 & 0 & 0 & 0 & 0 & 0 & 5 & 0 & 5 & 0 & 4 & 0 & 2 \\
\hline 9.1 .2 & 5 & 5 & 5 & 5 & 0 & 3 & 0 & 2 & 5 & 4 & 2 & 2 & 0 & 0 & 0 & 0 & 0 & 5 & 0 & 5 & 0 & 4 & 0 & 1 \\
\hline 9.2 .2 & 5 & 5 & 5 & 5 & 0 & 3 & 0 & 2 & 5 & 4 & 2 & 2 & 0 & 0 & 0 & 0 & 0 & 5 & 0 & 5 & 0 & 4 & 0 & 2 \\
\hline 10.1 .1 & 5 & 5 & 5 & 4 & 0 & 3 & 0 & 0 & 4 & 4 & 1 & 2 & 0 & 0 & 0 & 0 & 0 & 5 & 0 & 5 & 0 & 2 & 0 & 0 \\
\hline 10.2 .1 & 5 & 5 & 5 & 4 & 0 & 3 & 0 & 1 & 4 & 4 & 2 & 2 & 0 & 0 & 0 & 0 & 1 & 5 & 0 & 5 & 0 & 3 & 0 & 0 \\
\hline 10.1 .2 & 5 & 5 & 5 & 5 & 0 & 3 & 0 & 0 & 5 & 4 & 2 & 1 & 0 & 0 & 0 & 0 & 0 & 5 & 0 & 5 & 0 & 3 & 0 & 0 \\
\hline 10.2 .2 & 5 & 5 & 5 & 5 & 0 & 3 & 0 & 1 & 5 & 4 & 2 & 2 & 0 & 0 & 0 & 0 & 1 & 5 & 0 & 5 & 0 & 3 & 0 & 0 \\
\hline
\end{tabular}

R Repetições

L Leituras $\left(1^{\circ}\right.$ e $2^{\circ}$ dias $)$

D Duplicatas

$4^{\circ} \mathrm{C} \quad$ Temperatura de 4 Graus Celsius
Ta Temperatura ambiente $\left(20^{\circ}\right.$ a $\left.22^{\circ} \mathrm{C}\right)$

SMO Ausência de matéria orgânica

CMO Presença de matéria orgânica 
Apêndice C - Médias das contagens das U.F.C. de M.bovis em placas com 7H11, segundo o princípio ativo do desinfetante químico, a temperatura e contacto, presença ou ausência de matéria orgânica. São Paulo - 2007.

\begin{tabular}{|c|c|c|c|c|c|c|c|c|c|c|c|c|c|c|c|c|c|c|c|c|c|c|c|c|c|}
\hline \multirow{3}{*}{$\mathrm{R}$} & \multirow{3}{*}{$\mathrm{L}$} & \multicolumn{4}{|c|}{ Controle } & \multicolumn{4}{|c|}{ Hipoclorito de sódio } & \multicolumn{4}{|c|}{ Glutaraldeído } & \multicolumn{4}{|c|}{ Ácido peracético } & \multicolumn{4}{|c|}{ Iodóforo } & \multicolumn{4}{|c|}{ Fenol } \\
\hline & & \multicolumn{2}{|c|}{$4^{\circ} \mathrm{C}$} & \multicolumn{2}{|c|}{ TA } & \multicolumn{2}{|c|}{$4^{\circ} \mathrm{C}$} & \multicolumn{2}{|c|}{ TA } & \multicolumn{2}{|c|}{$4^{\circ} \mathrm{C}$} & \multicolumn{2}{|c|}{ TA } & \multicolumn{2}{|c|}{$4^{\circ} \mathrm{C}$} & \multicolumn{2}{|c|}{ TA } & \multicolumn{2}{|c|}{$4^{\circ} \mathrm{C}$} & \multicolumn{2}{|c|}{ TA } & \multicolumn{2}{|c|}{$4^{\circ} \mathrm{C}$} & \multicolumn{2}{|c|}{ TA } \\
\hline & & smo & $\mathrm{cmo}$ & smo & $\mathrm{Cmo}$ & Smo & $\mathrm{cmo}$ & smo & $\mathrm{cmo}$ & smo & $\mathrm{cmo}$ & smo & $\mathrm{cmo}$ & smo & $\mathrm{cmo}$ & smo & $\mathrm{cmo}$ & smo & $\mathrm{cmo}$ & smo & $\mathrm{cmo}$ & smo & $\mathrm{cmo}$ & smo & $\mathrm{cmo}$ \\
\hline \multirow[b]{2}{*}{$1^{\mathrm{a}}$} & 1 & 44,55 & 100,45 & 47,95 & 78,05 & 0 & 0 & 0 & 0 & 0 & 0 & 0 & 0 & 0 & 0 & 0 & 0 & 0 & 6,45 & 0 & 0 & 0 & 0,95 & 0 & 0 \\
\hline & 2 & 52,45 & 110,7 & 54,9 & 99,75 & 0 & 0 & 0 & 0 & 0 & 0 & 0 & 0 & 0 & 0 & 0 & 0 & 0 & 10 & 0 & 0 & 0 & 1,8 & 0 & 0 \\
\hline \multirow[b]{2}{*}{$2^{a}$} & 1 & 103,75 & 147,55 & 97,45 & 90,95 & 0 & 0 & 0 & 0 & 0 & 0 & 0 & 0 & 0 & 0 & 0 & 0 & 0 & 98,85 & 0 & 123,75 & 0 & 58,45 & 0 & 0 \\
\hline & 2 & 159,75 & 217,55 & 140,9 & 139,7 & 0 & 0 & 0 & 0 & 0 & 0 & 0 & 0 & 0 & 0 & 0 & 0 & 0 & 171,65 & 0 & 188,5 & 0 & 89,5 & 0 & 0 \\
\hline \multirow[b]{2}{*}{$3^{\mathrm{a}}$} & 1 & 87,1 & 71,7 & 113,4 & 44,7 & 0 & 0 & 0 & 0 & 0,3 & 2,6 & 0 & 0 & 0 & 0 & 0 & 0 & 0 & 72,9 & 0 & 92,4 & 0 & 2,05 & 0 & 0 \\
\hline & 2 & 111 & 95,95 & 130,2 & 100,45 & 0 & 0 & 0 & 0 & 1,75 & 10,2 & 0 & 0 & 0 & 0 & 0 & 0 & 0 & 92,45 & 0 & 121,1 & 0 & 7 & 0 & 0 \\
\hline \multirow[b]{2}{*}{$4^{\mathrm{a}}$} & 1 & 91,1 & 75,15 & 75,5 & 82,35 & 0 & 0,3 & 0 & 0 & 7,85 & 0,15 & 0 & 3,5 & 0 & 0 & 0 & 0 & 0 & 83,6 & 0 & 49,55 & 0 & 0,8 & 0 & 0 \\
\hline & 2 & 140,2 & 92,35 & 107 & 123,1 & 0 & 1,3 & 0 & 0 & 26,75 & 1,9 & 0 & 12,4 & 0 & 0 & 0 & 0 & 0 & 123 & 0 & 80,3 & 0 & 6,35 & 0 & 0 \\
\hline \multirow[b]{2}{*}{$5^{a}$} & 1 & 37 & 17,7 & 19,1 & 15,7 & 0 & 0 & 0 & 0 & 3,05 & 0,7 & 0 & 0 & 0 & 0 & 0 & 0 & 0 & 18,1 & 0 & 12,6 & 0 & 0,7 & 0 & 0 \\
\hline & 2 & 67,7 & 40,45 & 44,9 & 35,35 & 0 & 0 & 0 & 0 & 8,95 & 4,4 & 0 & 0 & 0 & 0 & 0 & 0 & 0 & 46,95 & 0 & 32,75 & 0 & 2,1 & 0 & 0 \\
\hline & 1 & 116,85 & 108,8 & 259,75 & 74,3 & 0 & 1 & 0 & 0 & 0,55 & 0 & 0 & 0 & 0 & 0 & 0 & 0 & 0 & 58,55 & 9,95 & 40,85 & 0 & 0 & 0 & 0 \\
\hline $6^{\mathrm{a}}$ & 1 & 193 & 172,75 & 306,25 & 108,5 & 0 & 4 & 0 & 0 & 4,4 & 0,1 & 0 & 0 & 0 & 0 & 0 & 0 & 0 & 95,75 & 21,85 & 79,3 & 0 & 0,05 & 0 & 0 \\
\hline & 1 & 137,75 & 120,15 & 115,65 & 67,45 & 0 & 0 & 0 & 0 & 0,25 & 9,5 & 0 & 0 & 0 & 0 & 0 & 0 & 0 & 132,25 & 0 & 124,7 & 0 & 14,9 & 0 & 2,65 \\
\hline $7^{\mathrm{a}}$ & 2 & 186,1 & 123,6 & 152,4 & 81,3 & 0 & 0 & 0 & 0 & 0,45 & 28,05 & 0 & 0 & 0 & 0 & 0 & 0 & 0 & 142,15 & 0 & 142,35 & 0 & 25,6 & 0 & 5 \\
\hline & 1 & 120,8 & 102,8 & 148,2 & 121,35 & 0 & 0 & 0 & 0 & 12,25 & 43,8 & 0 & 0 & 0 & 0 & 0 & 0 & 0 & 116 & 0 & 128,75 & 0 & 4 & 0 & 0 \\
\hline $8^{a}$ & 2 & 138,25 & 119,8 & 161,25 & 139,45 & 0 & 0 & 0 & 0 & 48,4 & 86,7 & 0 & 0 & 0 & 0 & 0 & 0 & 0 & 144,25 & 0 & 153,9 & 0 & 16,45 & 0 & 0 \\
\hline & 1 & 167,5 & 249 & 191,25 & 184,5 & 0 & 26,55 & 0 & 0 & 141,9 & 32,1 & 0 & 0 & 0 & 0 & 0 & 0 & 0 & 178,5 & 0 & 156,5 & 0 & 61,2 & 0 & 0 \\
\hline $9^{a}$ & 2 & 195 & 290,25 & 204,25 & 216,5 & 0 & 52,8 & 0 & 0 & 187,15 & 68,4 & 0,1 & 0 & 0 & 0 & 0 & 0 & 0 & 198,25 & 0 & 184,15 & 0 & 100,2 & 0 & 0,1 \\
\hline & 1 & 265,5 & 193,25 & 169,25 & 191,25 & 0 & 16,95 & 0 & 0 & 75,7 & 94,1 & 0,4 & 1,15 & 0 & 0 & 0 & 0 & 0 & 123,75 & 0 & 177,5 & 0 & 14,05 & 0 & 0 \\
\hline $10^{\mathrm{a}}$ & 2 & 273,25 & 196,25 & 185,5 & 197,75 & 0 & 21,5 & 0 & 0 & 95,35 & 107,6 & 1 & 2,2 & 0 & 0 & 0 & 0 & 0 & 138,75 & 0 & 185,15 & 0 & 18,25 & 0 & 0 \\
\hline
\end{tabular}

$\begin{array}{llll}\mathrm{R} & \text { Repetições } & \text { Ta } & \text { Temperatura ambiente }\left(20^{\circ} \text { a } 22^{\circ} \mathrm{C}\right) \\ \mathrm{L} & \text { Leituras }\left(1^{\circ} \text { e } 2^{\circ} \text { dias }\right) & \mathrm{SMO} & \text { Ausência de matéria orgânica } \\ 4^{\circ} \mathrm{C} & \text { Temperatura de } 4 \text { Graus Celsius } & \mathrm{CMO} & \text { Presença de matéria orgânica }\end{array}$ 
Apêndice D - Média dos escores de crescimento de M.bovis na superfície do meio de Stonebrik em tubos, segundo o princípio ativo do desinfetante químico, a temperatura de contacto e presença ou ausência de matéria orgânica. São Paulo - 2007.

\begin{tabular}{|c|c|c|c|c|c|c|c|c|c|c|c|c|c|c|c|c|c|c|c|c|c|c|c|c|c|}
\hline \multirow{3}{*}{$\mathrm{R}$} & \multirow{3}{*}{$\mathrm{L}$} & \multicolumn{4}{|c|}{ Controle } & \multicolumn{4}{|c|}{ Hipoclorito de sódio } & \multicolumn{4}{|c|}{ Glutaraldeído } & \multicolumn{4}{|c|}{ Ácido peracético } & \multicolumn{4}{|c|}{ Iodóforo } & \multicolumn{4}{|c|}{ Fenol } \\
\hline & & \multicolumn{2}{|c|}{$4^{\circ} \mathrm{C}$} & \multicolumn{2}{|c|}{ TA } & \multicolumn{2}{|c|}{$4^{\circ} \mathrm{C}$} & \multicolumn{2}{|c|}{ TA } & \multicolumn{2}{|c|}{$4^{\circ} \mathrm{C}$} & \multicolumn{2}{|c|}{ TA } & \multicolumn{2}{|c|}{$4^{\circ} \mathrm{C}$} & \multicolumn{2}{|c|}{ TA } & \multicolumn{2}{|c|}{$4^{\circ} \mathrm{C}$} & \multicolumn{2}{|c|}{ TA } & \multicolumn{2}{|c|}{$4^{\circ} \mathrm{C}$} & \multicolumn{2}{|c|}{ TA } \\
\hline & & smo & $\mathrm{cmo}$ & smo & $\mathrm{cmo}$ & Smo & $\mathrm{cmo}$ & smo & $\mathrm{cmo}$ & smo & $\mathrm{cmo}$ & smo & $\mathrm{cmo}$ & smo & $\mathrm{cmo}$ & smo & $\mathrm{cmo}$ & smo & $\mathrm{cmo}$ & smo & $\mathrm{cmo}$ & smo & $\mathrm{cmo}$ & smo & $\mathrm{cmo}$ \\
\hline \multirow[b]{2}{*}{$1^{\mathrm{a}}$} & 1 & 4 & 1 & 2 & 3 & 0 & 0 & 0 & 0 & 2,5 & 0,5 & 0 & 0 & 0 & 0 & 0 & 0 & 0 & 3,5 & 0 & 0 & 0 & 1 & 0 & 0 \\
\hline & 2 & 5 & 2 & 3,5 & 3 & 0 & 0 & 0 & 0 & 3 & 0,5 & 0 & 0 & 0 & 0 & 0 & 0 & 0 & 4 & 0 & 0,5 & 0 & 2 & 0 & 0 \\
\hline \multirow[b]{2}{*}{$2^{\mathrm{a}}$} & 1 & 4 & 2,5 & 2 & 4 & 0 & 0 & 0 & 0 & 0 & 0 & 0 & 0 & 0 & 0 & 0 & 0 & 0 & 3,5 & 0 & 4 & 0 & 1,5 & 0 & 0 \\
\hline & 2 & 4 & 3 & 2,5 & 4,5 & 0 & 0 & 0 & 0 & 1 & 0 & 0 & 0 & 0 & 0 & 0 & 0 & 0,5 & 4,5 & 0 & 5 & 0 & 2,5 & 0 & 0 \\
\hline \multirow[b]{2}{*}{$3^{\mathrm{a}}$} & 1 & 1,5 & 2 & 2 & 4 & 0 & 0 & 0 & 0 & 0 & 1,5 & 0 & 0 & 0 & 0 & 0 & 0 & 0 & 4 & 0 & 3 & 0 & 0 & 0 & 0 \\
\hline & 2 & 3,5 & 3 & 3,5 & 4 & 0 & 0 & 0 & 0 & 1 & 2 & 0 & 0 & 0 & 0 & 0 & 0 & 0 & 3,5 & 0,5 & 3 & 0 & 2 & 0 & 0 \\
\hline \multirow[b]{2}{*}{$4^{\mathrm{a}}$} & 1 & 2,5 & 2 & 3 & 3 & 0 & 0,5 & 0 & 0 & 3 & 0 & 0 & 0 & 0 & 0 & 0 & 0 & 0 & 4 & 0 & 2,5 & 0 & 1 & 0 & 0 \\
\hline & 2 & 4 & 3,5 & 3,5 & 3,5 & 0 & 1 & 0 & 0 & 4,5 & 1 & 0 & 0 & 0 & 0 & 0 & 0 & 0 & 5 & 0 & 3,5 & 0 & 2 & 0 & 0 \\
\hline \multirow[b]{2}{*}{$5^{\mathrm{a}}$} & 1 & 2,5 & 3,5 & 3 & 2,5 & 0 & 0 & 0 & 0 & 1,5 & 1 & 0 & 0 & 0 & 0 & 0 & 0 & 0 & 2,5 & 0 & 2 & 0 & 1 & 0 & 0 \\
\hline & 2 & 3,5 & 4,5 & 4 & 4 & 0 & 0 & 0 & 0 & 2,5 & 1 & 0 & 0 & 0 & 0 & 0 & 0 & 0 & 4 & 0 & 2,5 & 0 & 2 & 0 & 0 \\
\hline & 1 & 4 & 5 & 5 & 2,5 & 0 & 0,5 & 0 & 0 & 1 & 0,5 & 0 & 0 & 0 & 0 & 0 & 0 & 0 & 3 & 1 & 2,5 & 0 & 0 & 0 & 0 \\
\hline $6^{\mathrm{a}}$ & 1 & 5 & 5 & 5 & 4,5 & 0 & 2 & 0 & 0 & 2 & 2 & 0 & 0 & 0 & 0 & 0 & 0 & 0,5 & 4 & 2,5 & 4 & 0 & 1 & 0 & 0 \\
\hline & 1 & 3 & 3 & 5 & 3 & 0 & 0 & 0 & 0 & 0 & 1,5 & 0 & 0 & 0 & 0 & 0 & 0 & 0,5 & 2,5 & 0 & 2,5 & 0 & 1 & 0 & 0,5 \\
\hline $7^{\mathrm{a}}$ & 2 & 3 & 3 & 5 & 3 & 0 & 0 & 0 & 0 & 0 & 2 & 0 & 0 & 0 & 0 & 0 & 0 & 0,5 & 4 & 0 & 4 & 0 & 2 & 0 & 0,5 \\
\hline & 1 & 4 & 4 & 5 & 4 & 0 & 0 & 0 & 0 & 2,5 & 4 & 0 & 0 & 0 & 0 & 0 & 0 & 0 & 4 & 0 & 5 & 0 & 1 & 0 & 0 \\
\hline $8^{\mathrm{a}}$ & 2 & 4 & 4,5 & 5 & 4 & 0 & 0,5 & 0 & 0 & 4 & 4 & 0 & 0 & 0 & 0 & 0 & 0 & 0 & 4 & 0 & 5 & 0 & 2 & 0 & 0 \\
\hline & 1 & 4,5 & 4,5 & 4,5 & 4,5 & 0 & 3 & 0 & 0 & 5 & 4 & 2 & 2 & 0 & 0 & 0 & 0 & 0 & 5 & 0 & 5 & 0 & 4 & 0 & 1 \\
\hline $9^{a}$ & 2 & 4,5 & 4,5 & 4,5 & 4,5 & 0 & 3 & 0 & 0 & 5 & 4 & 2 & 2 & 0 & 0 & 0 & 0 & 0 & 5 & 0 & 5 & 0 & 4 & 0 & 2 \\
\hline & 1 & 5 & 5 & 5 & 4,5 & 0 & 3 & 0 & 0 & 4,5 & 4 & 1,5 & 1,5 & 0 & 0 & 0 & 0 & 0 & 5 & 0 & 5 & 0 & 2,5 & 0 & 0 \\
\hline $10^{\mathrm{a}}$ & 10.2 & 5 & 5 & 5 & 4,5 & 0 & 3 & 0 & 1 & 4,5 & 4 & 2 & 2 & 0 & 0 & 0 & 0 & 1 & 5 & 0 & 5 & 0 & 3 & 0 & 0 \\
\hline
\end{tabular}

\footnotetext{
R Repetições

Ta Temperatura ambiente $\left(20^{\circ}\right.$ a $\left.22^{\circ} \mathrm{C}\right)$

L Leituras $\left(1^{\circ}\right.$ e $2^{\circ}$ dias $)$

SMO Ausência de matéria orgânica

$4^{\circ} \mathrm{C}$ Temperatura de 4 Graus Celsius CMO Presença de matéria orgânica
} 
Apêndice E - Valores de significância p para a comparação dos resultados obtidos nas placas com meio 7H11 pelos produtos químicos testados frente à estirpe de $M$. bovis, nas condições estabelecidas. São Paulo - 2007. São Paulo - 2007

\begin{tabular}{|c|c|c|c|c|}
\hline Desinfetante & $\mathrm{SMO} 4^{\circ} \mathrm{C}$ & $\mathrm{CMO} 4^{\circ} \mathrm{C}$ & SMO Ta & CMO Ta \\
\hline $\mathrm{B} \times \mathrm{C}$ & $\mathrm{p}<0,001$ & $\mathrm{p}>0,05$ & $\mathrm{p}>0,05$ & $\mathrm{p}>0,05$ \\
\hline$B \times D$ & $\mathrm{p}>0,05$ & $\mathrm{p}>0,05$ & $\mathrm{p}>0,05$ & $\mathrm{p}>0,05$ \\
\hline$B \times E$ & $\mathrm{p}>0,05$ & $\mathrm{p}<0,001$ & $\mathrm{p}>0,05$ & $\mathrm{p}<0,001$ \\
\hline $\mathrm{B} \times \mathrm{F}$ & $\mathrm{p}>0,05$ & $\mathrm{p}>0,05$ & $\mathrm{p}>0,05$ & $\mathrm{p}>0,05$ \\
\hline $\mathrm{C} \times \mathrm{D}$ & $\mathrm{p}<0,001$ & $\mathrm{p}<0,05$ & $\mathrm{p}>0,05$ & $\mathrm{p}>0,05$ \\
\hline $\mathrm{C} \times \mathrm{E}$ & $\mathrm{p}<0,001$ & $\mathrm{p}>0,05$ & $\mathrm{p}>0,05$ & $\mathrm{p}<0,001$ \\
\hline $\mathrm{C} \times \mathrm{F}$ & $\mathrm{p}<0,001$ & $\mathrm{p}>0,05$ & $\mathrm{p}>0,05$ & $\mathrm{p}>0,05$ \\
\hline$D \times E$ & $\mathrm{p}>0,05$ & $\mathrm{p}<0,01$ & $\mathrm{p}>0,05$ & $\mathrm{p}<0,001$ \\
\hline $\mathrm{D} \times \mathrm{F}$ & $\mathrm{p}>0,05$ & $\mathrm{p}<0,05$ & $\mathrm{p}>0,05$ & $\mathrm{p}>0,05$ \\
\hline $\mathrm{E} \times \mathrm{F}$ & $\mathrm{p}>0,05$ & $\mathrm{p}>0,05$ & $\mathrm{p}>0,05$ & $\mathrm{p}<0,001$ \\
\hline
\end{tabular}

B Hipoclorito de sódio

C Glutaraldeído

D Ácido peracético

E Iodóforo

F Fenol $4^{\circ} \mathrm{C} \quad$ Temperatura de 4 Graus Celsius

Ta Temperatura ambiente $\left(20^{\circ}\right.$ a $\left.22^{\circ} \mathrm{C}\right)$

SMO Ausência de matéria orgânica

CMO Presença de matéria orgânica 
Apêndice F - Valores de significância p para a comparação dos resultados obtidos nos tubos com Stonebrink pelos produtos químicos testados frente à estirpe de M. bovis, nas condições estabelecidas. São Paulo - 2007

\begin{tabular}{|c|c|c|c|c|}
\hline Desinfetante & $\mathrm{SMO} 4^{\circ} \mathrm{C}$ & $\mathrm{CMO} 4^{\circ} \mathrm{C}$ & SMO Ta & CMO Ta \\
\hline $\mathrm{B} \times \mathrm{C}$ & $\mathrm{p}<0,001$ & $\mathrm{p}>0,05$ & $\mathrm{p}>0,05$ & $\mathrm{p}>0,05$ \\
\hline$B \times D$ & $\mathrm{p}>0,05$ & $\mathrm{p}>0,05$ & $\mathrm{p}>0,05$ & $\mathrm{p}>0,05$ \\
\hline$B \times E$ & $\mathrm{p}>0,05$ & $\mathrm{p}<0,001$ & $\mathrm{p}>0,05$ & $\mathrm{p}<0,001$ \\
\hline $\mathrm{B} \times \mathrm{F}$ & $\mathrm{p}>0,05$ & $\mathrm{p}>0,05$ & $\mathrm{p}>0,05$ & $\mathrm{p}>0,05$ \\
\hline $\mathrm{C} \times \mathrm{D}$ & $\mathrm{p}<0,001$ & $\mathrm{p}<0,05$ & $\mathrm{p}>0,05$ & $\mathrm{p}>0,05$ \\
\hline $\mathrm{C} \times \mathrm{E}$ & $\mathrm{p}<0,05$ & $\mathrm{p}>0,05$ & $\mathrm{p}>0,05$ & $\mathrm{p}<0,001$ \\
\hline $\mathrm{C} \times \mathrm{F}$ & $\mathrm{p}<0,001$ & $\mathrm{p}>0,05$ & $\mathrm{p}>0,05$ & $\mathrm{p}>0,05$ \\
\hline$D \times E$ & $p>0,05$ & $\mathrm{p}<0,001$ & $\mathrm{p}>0,05$ & $\mathrm{p}<0,001$ \\
\hline $\mathrm{D} \times \mathrm{F}$ & $\mathrm{p}>0,05$ & $\mathrm{p}<0,01$ & $\mathrm{p}>0,05$ & $\mathrm{p}>0,05$ \\
\hline $\mathrm{E} \times \mathrm{F}$ & $\mathrm{p}>0,05$ & $\mathrm{p}>0,05$ & $\mathrm{p}>0,05$ & $\mathrm{p}<0,001$ \\
\hline
\end{tabular}

B Hipoclorito de sódio

C Glutaraldeído

D Ácido peracético

E Iodóforo

F Fenol $4^{\circ} \mathrm{C} \quad$ Temperatura de 4 Graus Celsius

Ta Temperatura ambiente $\left(20^{\circ}\right.$ a $\left.22^{\circ} \mathrm{C}\right)$

SMO Ausência de matéria orgânica

CMO Presença de matéria orgânica 